
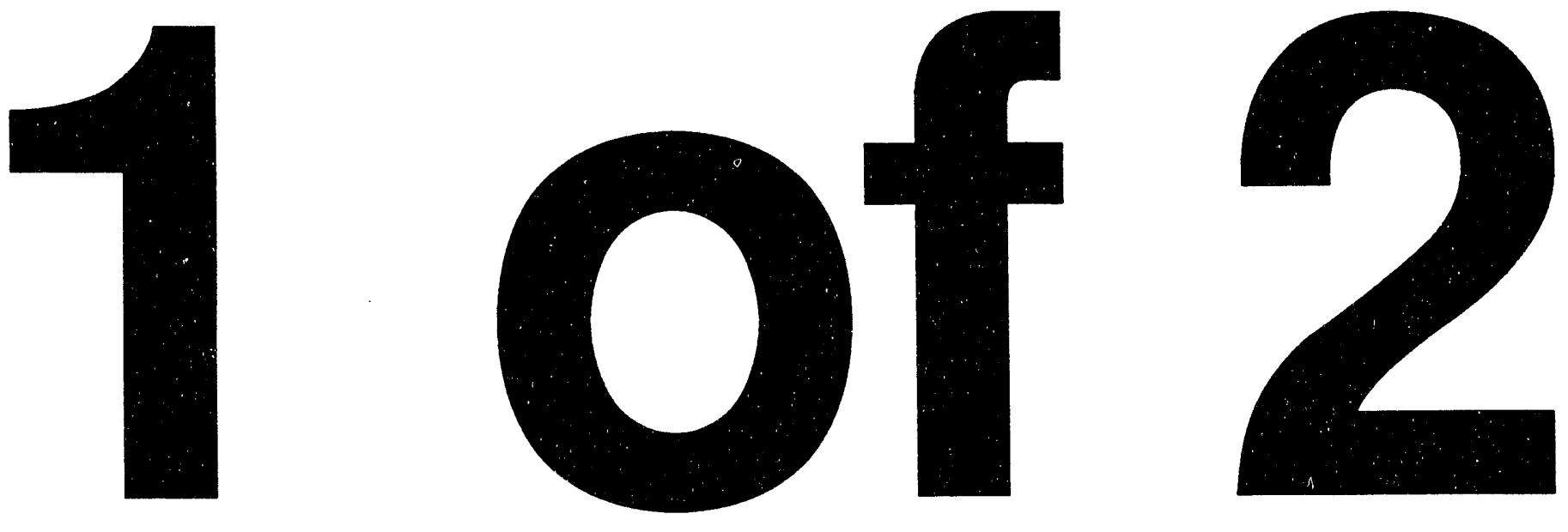


\section{BASELINE RISK AsSESSMENT OF GROUND WATER CONTAMINATION AT THE INACTIVE URANIFEROUS Lignite Ashing Site NeAR BelfielD, NORTH DAKota}

August 1994

RECEIVED

SEP 12 1994

OSTI 
This report has been reproduced from the best available copy. Available in paper copy and microfiche.

Number of pages in this report: 128

DOE and DOE contractors can obtain copies of this report from:

Office of Scientific and Technical Information

P.O. Box 62

Oak Ridge, TN 37831

(615) 576-8401

This report is publicly available from:

National Technical Information Service

Department of Commerce

5285 Port Royal Road

Springfield, VA 22161

(703) $487-4650$ 


\title{
BASELINE RISK ASSESSMENT OF GROUND WATER CONTAMINATION AT THE INACTIVE URANIFEROUS LIGNITE ASHING SITE NEAR BELFIELD, NORTH DAKOTA
}

\section{August 1994}

\author{
Prepared for \\ U.S. Department of Energy \\ UMTRA Project Office \\ Albuquerque, New Mexico \\ Prepared by \\ Jacobs Engineuring Group Inc. \\ Albuquerque, New Mexico
}

\section{DISCLAIMER}

This report was prepared as an account of work sponsored by an agency of the United States Government. Neither the United States Government nor any agency thereof, nor any of their employees, makes any warranty, express or implied, or assumes any legal liability or responsibility for the accuracy, completeness, or usefulness of any information, apparatus, product, or process disclosed, or represents that its use would not infringe privately owned rights. Reference herein to any specific commercial product, process, or service by trade name, trademark, manufacturer, or otherwise does not necessarily constitute or imply its endorsement, recommendation, or favoring by the United States Government or any agency thereof. The views and opinions of authors expressed herein do not necessarily state or reflect those of the United States Government or any agency thereof. 


\section{CITIZENS' SUMMARY}

This Baseline Risk Assessment of Ground Water Contamination at the Inactive Uraniferous Lignite Ashing Site Near Belfield, North Dakota, evaluates potential impacts to public health or the environment resulting from ground water contamination at the site where coal containing uranium was burned to produce uranium. The U.S. Department of Energy's Uranium Mill Tailings Remedial Action (UMTRA) Project is evaluating plans to remedy soil and ground water contamination at the site. Phase I of the UMTRA Project consists of determining the extent of soil contamination. Phase II of the UMTRA Project consists of evaluating ground water contamination. Under Phase II, results of this risk assessment will help determine what remedial actions may be necessary for contaminated ground water at the site.

This risk assessment evaluates the potential risks to human health and the environment resulting from exposure to contaminated ground water as it relates to historic processing activities at the site. Potential risk is quantified for constituents introduced from the processing activities, and not for those constituents naturally occurring in water quality in the site vicinity. Background ground water quality has the potential to cause adverse health effects froin exposure through drinking. Any risks associated with contaminants attributable to site activities are incremental to these risks from background ground water quality. This incremental risk from site-related contaminants is quantified in this risk assessment. The baseline risk from background water quality is incorporated only into the assessment of potential chemical interactions and the definition of the overall site condition.

\section{Potential public health impacts}

There are currently no domestic or drinking water wells in ground water contaminated by the site. The town of Belfield is supplied with municipal water, and no site-related ground water contamination has been identified in domestic wells monitored within 1 mile (1.6 kilometers) of the site. Because no one is drinking the site-affected water and there is no surface expression of contaminated ground water, there are currently no health or environmental risks associated with the contaminated ground water. However, ground water in the site vicinity is used for drinking water. For this reason, this risk assessment evaluates the potential future use of contaminated ground water.

This risk assessment follows the basic approach prescribed by the U.S. Environmental Protection Agency. The first step is to evaluate ground water data collected from monitor wells at and around the site over the last 8 years. Evaluation of these data showed that the main contaminants associated with the site are uranium and vanadium.

The next step in the risk assessment is to estimate how much of these contaminants people would be exposed to if a drinking water well were installed in the site contaminated ground water. Because contaminant concentrations vary each time a well is sampled and because people vary in how much they weigh and drink, this risk assessment uses probability distributions to determine the amounts of contaminants that would likely be ingested by people if they had a well at the site. The probability distributions describe how likely it is that something will happen. For example, within a given group of people, 
the range of tap water consumption rates or body weights is taken into consideration in the probability distributions.

These estimated amounts of contaminants that people might take in by consuming tap water are then compared to the toxic effects these contaminant levels might cause. Based on this analysis for the Belfield site, no adverse health effects would be expected following ingestion of contaminated ground water through drinking. However, because information on the carcinogenicity of uranium at the levels found at the site is limited, it cannot be assumed that carcinogenic health effects will not occur.

\section{Potential environmental impacts}

Potential impacts to the environment from site-contaminated ground water are not likely at the Belfield site. This risk assessment evaluated potential adverse effects to aquatic and terrestrial biota and to livestock. Measurements of the health of the ecological receptors at the site are limited; however, no adverse impacts are expected to birds, plants, wildlife, or livestock. No current surface water exposure pathways to biota exist because depth to ground water in the vicinity of the site is approximately 30 feet (10 meters) with no surface expression. Levels of contaminants of potential concern in surface water and sediment did not exceed any of the available water or soil quality criteria and guidelines. Aquatic species are not expected in the Heart River near the site because it is dry most of the time.

Based on results from future site monitoring activities and from this risk assessment, the DOE will propose an approach for managing contaminated ground water at the Belfield site. The overall ground water decision-making framework is presented in the UMTRA Project Programmatic Environmental Impact Statement for the Uranium Mill Tailings Remedial Action Ground Water Project. Site-specific remedial action decisions are planned for inclusion in either an environmental assessment or environmental impact statement, which will incorporate public input. Implementation of the ground water remedial action decision-making process is under evaluation for the Belfield site. 


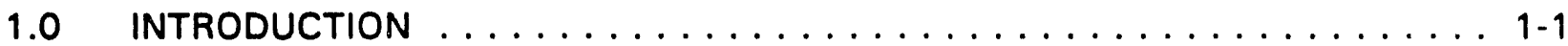

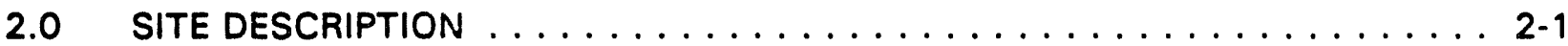

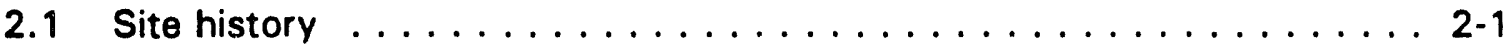

2.2 Climate ............................ 2-4

2.3 Ground water . . . . . . . . . . . . . . . . . 2-4

2.3.1 Hydrogeology . . . . . . . . . . . . . . . . . 2-4

2.3.2 Hydraulic characteristics . . . . . . . . . . . . . . 2-6

2.3.3 Ground water monitoring . . . . . . . . . . . . . . . . 2-9

2.4 Surface water ........................... 2-9

2.4.1 Surface water hydrology . . . . . . . . . . . . . . . 2-9

2.4.2 Surface water monitoring . . . . . . . . . . . . . 2-9

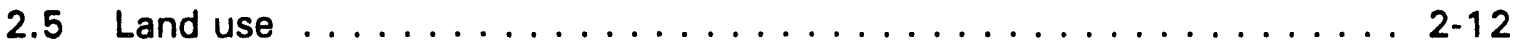

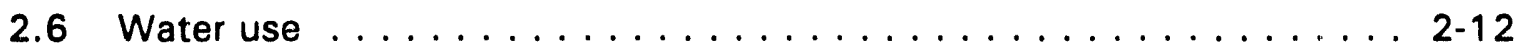

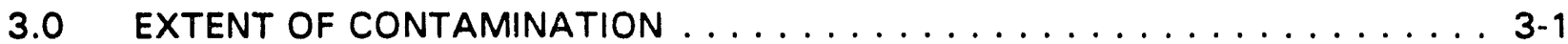

3.1 Background ground water quality data summary . . . . . . . . . 3-4

3.1.1 Regional background ground water quality . . . . . . . . 3-4

3.1.2 Background ground water quality in the Belfield site vicinity . . 3-4

3.2 Magnitude of site-related ground water contamination . . . . . . . . 3-6

3.2.1 Site-related contamination in the upper zone . . . . . . . . 3-7

3.2.2 Site-related contamination in the lignite zone . . . . . . . . 3-14

3.3 Contaminants of potential concern . . . . . . . . . . . . 3-21

3.4 Contaminant fate and transport . . . . . . . . . . . . 3-23

3.5 Surface water quality data summary $\ldots \ldots \ldots \ldots \ldots \ldots \ldots \ldots$

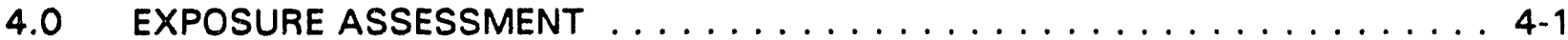

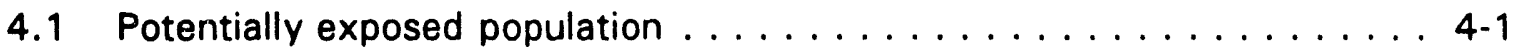

4.2 Exposure pathways ........................ 4-1

4.2.1 Drinking water ingestion ................. 4-2

4.2.2 Dermal absorption ..................... 4-2

4.2.3 Ingestion of ground water-irrigated produce . . . . . . . . . 4-5

4.2.4 Ingestion of milk or meat from ground water-fed livestock . . 4-5

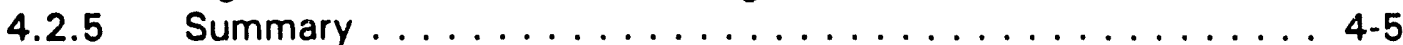

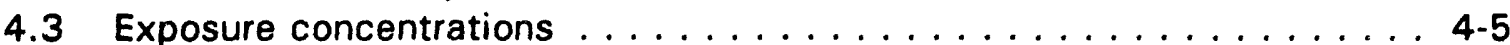

4.4 Estimation of intake . . . . . . . . . . . . . . . . . . 4-9

4.5 Exposure assessment uncertainties . . . . . . . . . . . . 4 4-15

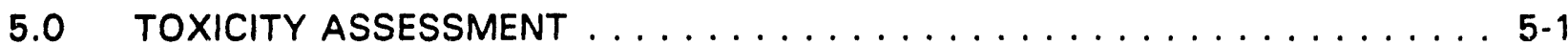

5.1 Contaminant toxicity summaries . . . . . . . . . . . . . . 5-1

5.1 .1 Uranium ....................... 5-1

5.1 .2 Vanadium ...................... $5-4$ 


\section{TABLE OF CONTENTS (Concluded)}

Section

Page

5.2 Contaminant interactions . . . . . . . . . . . . . . . . 5-9

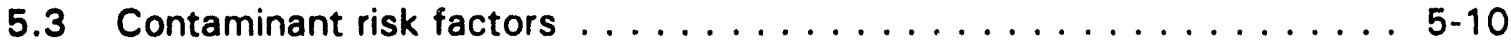

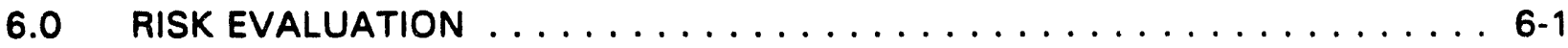

6.1 Potential noncarcinogenic health effects . . . . . . . . . . . 6-1

6.2 Potential carcinogenic health effects . . . . . . . . . . . . . . 6-4

6.3 Limitations of risk evaluation $\ldots \ldots \ldots \ldots \ldots \ldots \ldots \ldots \ldots$

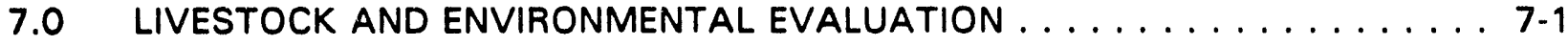

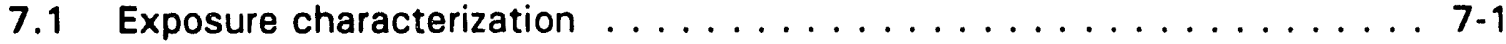

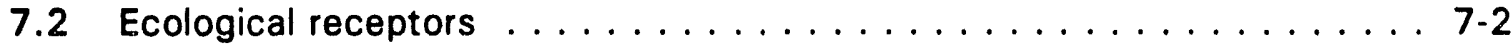

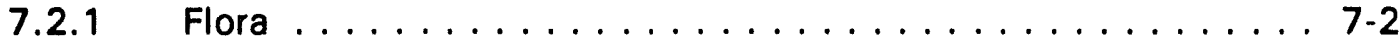

7.2 .2 Fauna ........................ 7-4

7.2.3 Aquatic organisms ................ 7-5

7.3 Contaminants of potential ecological concern $\ldots \ldots \ldots \ldots \ldots \ldots \ldots$

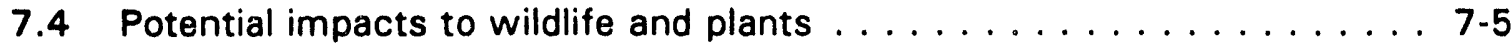

7.4.1 Future risk from ground water . . . . . . . . . . . 7-5

7.4.2 Current risk from surface water . . . . . . . . . . 7-8

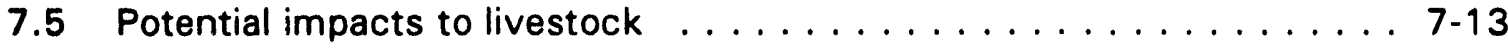

7.6 Uncertainties of the ecological risk assessment $\ldots \ldots \ldots \ldots \ldots \ldots$ 7-13

7.7 Summary ........................ 7-13

8.0 INTERPRETATION AND RECOMMENDATIONS $\ldots \ldots \ldots \ldots \ldots \ldots \ldots \ldots$

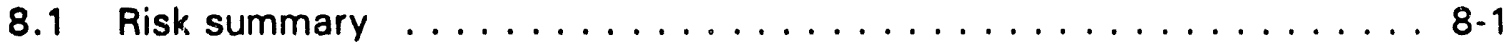

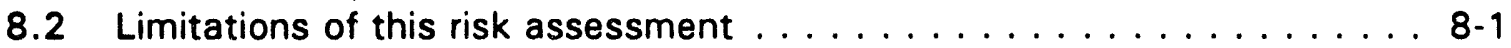

8.3 Ground water criteria $\ldots \ldots \ldots \ldots \ldots \ldots \ldots \ldots \ldots \ldots \ldots$

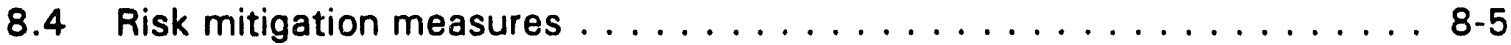

8.5 Future site activities $\ldots \ldots \ldots \ldots \ldots \ldots \ldots \ldots \ldots \ldots$

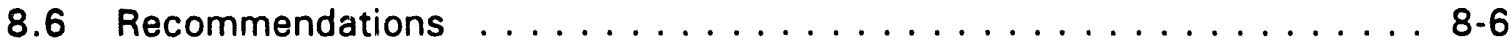

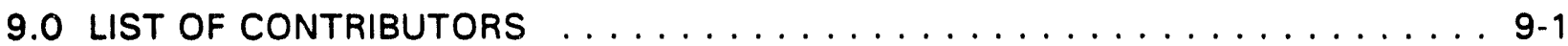

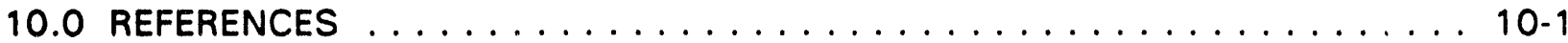




\section{LIST OF FIGURES}

Figure

2.1 Belfield site location map, Belfield, North Dakota . . . . . . . . . . . . 2-2

2.2 Site description of the Belfield designated site, North Dakota . . . . . . . . . . 2-3

2.3 Hydrogeologic cross section A-A', Belfield, North Dakota, site . . . . . . . . . 2-5

2.4 Potentiometric surface of the upper zone at the Belfield, North Dakota, site . . 2-7

2.5 Potentiometric surface of the lignite zone at the Belfield, North Dakota, site . . 2-8

2.6 Ground water sampling locations at the Belfield, North Dakota, site . . . . . 2-10

2.7 Surface water sampling locations in the vicinity of the Belfield, North Dakota, site . . . . . . . . . . . . . . . . . . . . . . 2-11

2.8 Land use in the vicinity of the Belfield, North Dakota, site . . . . . . . . . 2-13

3.1 Extent of surface contamination, Belfield, North Dakota, site . . . . . . . . . . . 3-2

3.2 Trends in uranium concentrations in upper zone, Belfield, North Dakota, site . 3-13

4.1 Belfield exposure pathways conceptual model . . . . . . . . . . . . . . 4-3

4.2 Simulated distribution of vanadium concentrations, Belfield, North Dakota, site ................................ 4-10

4.3 Simulated distribution of uranium concentrations, Belfield, North Dakota, site 4-11

4.4 Probability distributions for tap water ingestion rates . . . . . . . . . . . 4-13

4.5 Probability distributions for body weight . . . . . . . . . . . . . 4-14

4.6 Probability distribution of uranium intakes for children as a result of ground water ingestion, Belfield, North Dakota, site . . . . . . . . . . . . . . . . . 4-16

4.7 Probability distribution of vanadium intakes for children as a result of ground water ingestion, Belfield, North Dakota, site . . . . . . . . . . . . . . 4-17

5.1 Half-lives and emissions from decay chain of uranium-238 $\ldots \ldots \ldots \ldots \ldots-2$

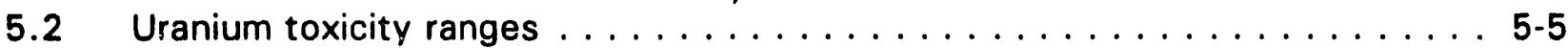

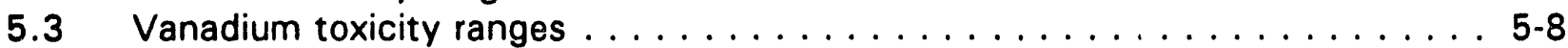

6.1 Health effects of potential vanadium exposure ranges for children,

Belfield, North Dakota, site . . . . . . . . . . . . . . . . . . . . . . . . 6-2

6.2 Health effects of potential uranium exposure ranges for children,

Belfield, North Dakota, site . . . . . . . . . . . . . . . . . . . . . . 6-3

7.1 Plant community types, Belfield, North Dakota, site $\ldots \ldots \ldots \ldots \ldots \ldots$ 


\section{LIST OF TABLES}

Table

3.1 Monitor well information for the Belfield, North Dakota, site . . . . . . . . 3-3

3.2 Summary of filtered ground water quality data in the upper zone at Belfield, North Dakota $(1986-1993) \ldots \ldots$. . . . . . . . . . . . . . . . . . . . . . . . . . 3-8

3.3 Summary of filtered ground water quality data in the lignite zone at Belfield, North Dakota (1986-1993) . . . . . . . . . . . . . . . . . . . . . . . 3-15

3.4 Contaminants of potential concern for human health evaluation . . . . . . . 3-21

3.5 Aqueous species of constituents of potential concern in ground water beneath the Belfield, North Dakota, site . . . . . . . . . . . . . . . . . . . . . 3-24

3.6 Summary of filtered surface water quality at Belfield, North Dakota (1986-1988) . . . . . . . . . . . . . . . . . . . . . . . . . .

4.1 Exposure dose calculations and equation definitions for ground water ingestion and dermal contact, Belfield UMTRA Project site, Belfield, North Dakota . . . . . . . . . . . . . . . . . . . . . . . . . . . . . . . 4-4

4.2 Exposure dose calculations and equation definitions for ingestion of ground water-irrigated garden produce, Belfield UMTRA Project site, Belfield, North Dakota . . . . . . . . . . . . . . . . . . . . . . . . . . . . . 4-6

4.3 Exposure dose calculations and equation definitions for ingestion of milk from ground water-fed livestock, Belfield UMTRA Project site, Belfield, North Dakota . . . . . . . . . . . . . . . . . . . . . . . . . . . . . . . .

4.4. Exposure dose calculations and equation definitions for ingestion of meat from ground water-fed livestock, Belfield UMTRA Project site, Belfield, North Dakota . . . . . . . . . . . . . . . . . . . . . . . . . . .

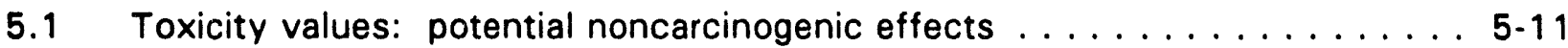

5.2 Toxicity values: potential carcinogenic effects . . . . . . . . . . . . 5-12

6.1 Excess lifetime cancer risk calculations for ground water ingestion by a hypothetical future adult resident, Belfield UMTRA Project site, Belfield, North Dakota . . . . . . . . . . . . . . . . . . . . . . . . . . . . . 6-4

7.1 Comparison of estimated plant concentrations to phytotoxic concentrations, Belfield UMTRA Project site, Belfield, North Dakota . . . . . . . . . . . . . . . 7-7

7.2 Comparison of contaminants above background levels in ground water at the site with available surface water quality values, Belfield UMTRA Project site, Belfield, North Dakota . . . . . . . . . . . . . . . . . . . . . . .

7.3 Comparison of surface water concentrations of ground water contaminants above background levels at the site with available surface water quality values for livestock, Belfield UMTRA Project site, Belfield, North Dakota . . . 7-10

7.4 The occurrence of metals in sediment samples collected from the Heart River in the site vicinity for comparison with available sediment quality values, Belfield UMTRA Project site, Belfield, North Dakota

8.1 Concentration limits $\ldots \ldots \ldots \ldots \ldots \ldots \ldots \ldots \ldots \ldots \ldots$ 


\section{LIST OF ACRONYMS AND ABBREVIATIONS}

Acronym

ac

$A C L$

ATSDR

BCF

${ }^{\circ} \mathrm{C}$

$\mathrm{cm}$

$\mathrm{cm}^{2}$

$\mathrm{cm}^{3}$

$\mathrm{cm} / \mathrm{s}$

DHHS

DOE

EPA

ER-L

ER-M

OF

FDA

$\mathrm{ft}$

FWS

ha

HEAST

IRIS

Kd

$\mathrm{kg} / \mathrm{day}$

$\mathrm{km}$

$\mu g$

$\mu \mathrm{g} / \mathrm{L}$

$\mu \mathrm{g} / \mathrm{kg}$

$\mathrm{m}$

$M C L$

$\mathrm{mg} / \mathrm{L}$

$\mathrm{mg} / \mathrm{kg}$

$\mathrm{mg} / \mathrm{kg}$-day

$\mathrm{mi}$

ng

$\mathrm{ng} / \mathrm{mL}$

NOAA

$\mathrm{pCi}$

$\mathrm{pCi} / \mathrm{L}$

PEIS

RDA

RfD

SF

SQC

T\&E

TDS

UMTRA

UMTRCA

\section{Definition}

acre

alternate concentration limit

Agency for Toxic Substances and Disease Registry

bioconcentration factor

degrees Celsius

centimeter

square centimeter

cubic centimeter

centimeters per second

Department of Health and Human Services

U.S. Department of Energy

U.S. Environmental Protection Agency

effects range-low

effects range-median

degrees Fahrenheit

U.S. Federal Drug Administration

foot

U.S. Fish and Wildlife Service

hectare

Health Effects Assessment Summary Tables

Integrated Risk Information System

distribution coefficient

kilograms per day

kilometer

microgram

micrograms per liter

micrograms per kilogram

meter

maximum concentration limit

milligrams per liter

milligrams per kilogram

milligrams per kilogram per day

miles

nanogram

nanograms per milliliter

National Oceanic and Atmospheric Administration

picocurie

picocuries per liter

programmatic environmental impact statement

recommended daily allowance

reference dose

slope factor

sediment quality criteria

threatened and endangered

total dissolved solids

Uranium Mill Tailings Remedial Action

Uranium Mill Tailings Radiation Control Act 


\subsection{INTRODUCTION}

The purpose of this baseline risk assessment is to determine whether ground water contamination at the uraniferous lignite ashing site in Belfield, North Dakota, has the potential to adversely affect public health or the environment. The Belfield site is one of 24 abandoned uranium mill tailings sites undergoing remediation in accordance with the requirements of the Uranium Mill Tailings Radiation Control Act (UMTRCA) of 1978 (42 USC $\$ 7901$ et seq.) under the oversight of the U.S. Department of Energy (DOE) Uranium Mill Tailings Remedial Action (UMTRA) Project.

Under the UMTRA Surface Project, the DOE stabilizes residual radioactive materials in a disposal cell to minimize radon and other radiation emissions and prevent further contamination of ground water. Surface remedial action plans for the Belfield site are currently under evaluation.

Under the UMTRA Ground Water Project, ground water contamination will be evaluated to determine the need for any remedial action and, if so, to implement that action. The DOE is authorized to perform ground water restoration under 1.988 amendments to the UMTRCA.

The Programmatic Environmental Impact Statement for the Uranium Mill Tailings Remedial Action Ground Water Project (DOE, 1994) describes the evaluation strategy and methodology for cleaning up contaminated ground water at the UMTRA Project sites. This baseline risk assessment is the first site-specific document prepared to evaluate potential health and environmental risks and to provide information that will help in determining what, if any, remedial action is required. Based on the programmatic environmental impact statement (PEIS), additional ground water characterization, and this risk assessment, a site-specific environmental assessment is planned to evaluate and select a remedial action. Implementation of the ground water remedial action decision-making process is currently under evaluation for the Belfield site.

The risk assessment is a baseline assessment in the sense that it describes pre-remediation ground water conditions at the site, with ground water contamination only partially characterized. Nonetheless, this document evaluates the potential for imminent public health or environmental risk that may need attention before the site is fully characterized.

This evaluation is based on available ground water data from the most contaminated wells at the processing site, and only major exposure pathways have been thoroughly examined. If future data collection, decisions, or actions at this site cause conditions to change, other pathways will be evaluated in more detail.

This risk assessment follows the basic framework prescribed by the U.S. Environmental Protection Agency (EPA) (EPA, 1989a) for evaluating hazardous waste sites to assess potential health and environmental impacts resulting from ground water contamination. The risk assessment process consists of the following steps: 
- Data evaluation.

- Combining existing data from various site investigations.

- Comparing sample results with background and tailings source data.

- Selecting chemical data for use in the risk assessment.

- Exposure assessment.

- Characterizing exposure settings.

- Identifying exposure pathways.

- Quantifying the exposure.

- Toxicity assessment.

- Identifying toxicity values.

- Evaluating noncarcinogenic effects.

- Evaluating carcinogenic effects from radionuclides and chemical carcinogens.

- Public health risk characterization.

- Comparing toxicity ranges with predicted exposure ranges.

- Combining risks across exposure pathways and multiple contaminants.

- Characterizing uncertainties.

- Environmental risk.

- Characterizing potential biota exposure pathways.

- Identifying potential ecological receptors.

- Evaluating the environmental risk qualitatively.

This framework is used to estimate the risks from potential use of contaminated ground water and surface water near the Belfield site. It is incorporated into the methodology used to evaluate human health risk at UMTRA Project sites. A report describing this methodology is in preparation. 


\subsection{SITE DESCRIPTION}

The 10.7-acre (ac) (4.3-hectare (hal) inactive Belfield lignite ashing site in Stark County, North Dakota, is immediately southeast of the town of Belfield. Belfield is approximately $3 \mathrm{mi}(5 \mathrm{~km})$ east of the Billings County-Stark County line and $19 \mathrm{mi}(31 \mathrm{~km})$ west of Dickinson, North Dakota, in Section 4, Township 139 north, Range 99 west, Fifth Principal Meridian (Figure 2.1). The site is situated between the Burlington Northern Railroad tracks on the south and the North Branch of the Heart River on the north (Figure 2.2). U.S. Highway 85 runs north and south $0.25 \mathrm{mi}(0.4 \mathrm{~km})$ west of the site.

\subsection{SITE HISTORY}

The Burlington Northern Railroad Company or its predecessors have owned much of the site since 1888. From 1964 to 1966, Union Carbide Corporation leased land from the Burlington Northern Raiiroad and private landowners R.M. and G.E. Newton for the construction and operation of a uraniferous lignite ashing plant.

Wet uraniferous lignite was shipped in from mines in the surrounding area and burned in an 8-foot $(\mathrm{ft})(2.4$-meter $[\mathrm{m}])$-diameter by $125-\mathrm{ft}(38-\mathrm{m})$-long rotary kiln. The kiln had a 100-ton (91-tonne) per day capacity, with an average production rate of approximately 60 tons (54 tonnes) per day. Combustion of organic material was the only processing at the site. No chemical, metallurgical, or nuclear processes were involved. The ash handling system was completely enclosed to control dust releases. A cyclone and scrubber system separated the dust from the kiln off-gas stream, while a stack released the off-gas to the atmosphere. Ash from the kiln was air-cooled in a rotary cooler, then loaded into covered railroad cars for shipment to Union Carbide's uranium mill in Rifle, Colorado (DOE, 1990). Union Carbide suspended ashing operations at Belfield in October 1966 and in August 1968 sold the plant to Dakota Industries, Inc. Between these dates, the plant, equipment, buildings, and yard were cleaned and decontaminated to meet the then-current U.S. Atomic Energy Commission requirements.

After ashing operations ceased, Dakota Industries constructed a building at the site approxirnately $100 \mathrm{ft}(30 \mathrm{~m})$ east of the uriginal kiln foundation for the calcination of clay. Dakota Industries stopped operations in 1971 and sold the building to the L.P. Anderson Company. The L.P. Anderson Company also leased the land east of the building from the Burlington Northern Railroad for equipment maintenance and storage. G.R. and J.A. Newton subsequently acquired land surrounding the processing site, including the R.M. and G.E. Newton tract previously leased as part of the processing site (FBDU, 1981). The Burlington Northern Railroad and G.R. and J.A. Newton of Belfield still own the land occupied by. and surrounding the processing site. A petroleum exploration company (Cenex) and a rabbit grower/honey processor also previously occupied the site (DOE, 1990). 


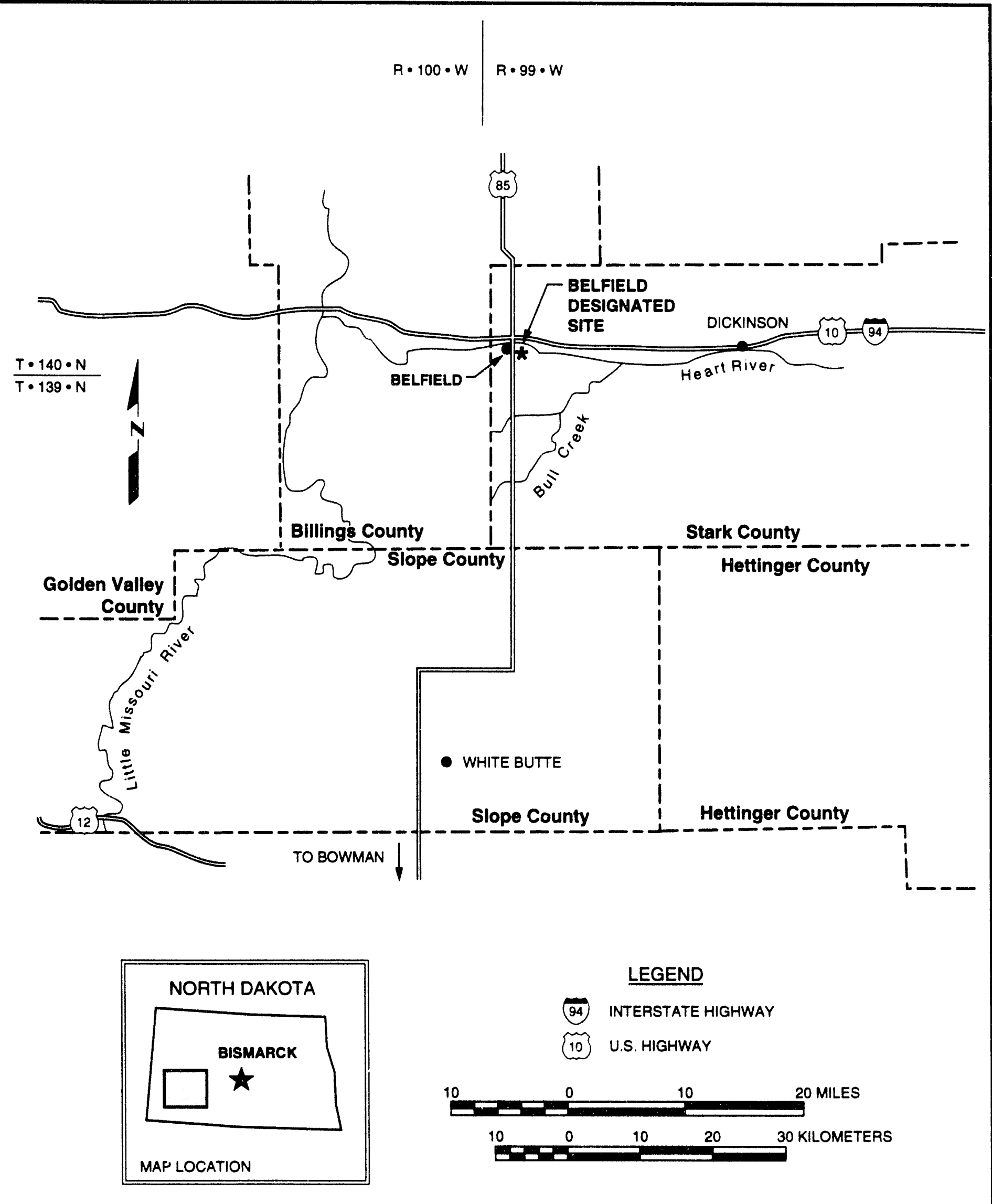

FIGURE 2.1

BELFIELD SITE LOCATION MAP

BELFIELD, NORTH DAKOTA 


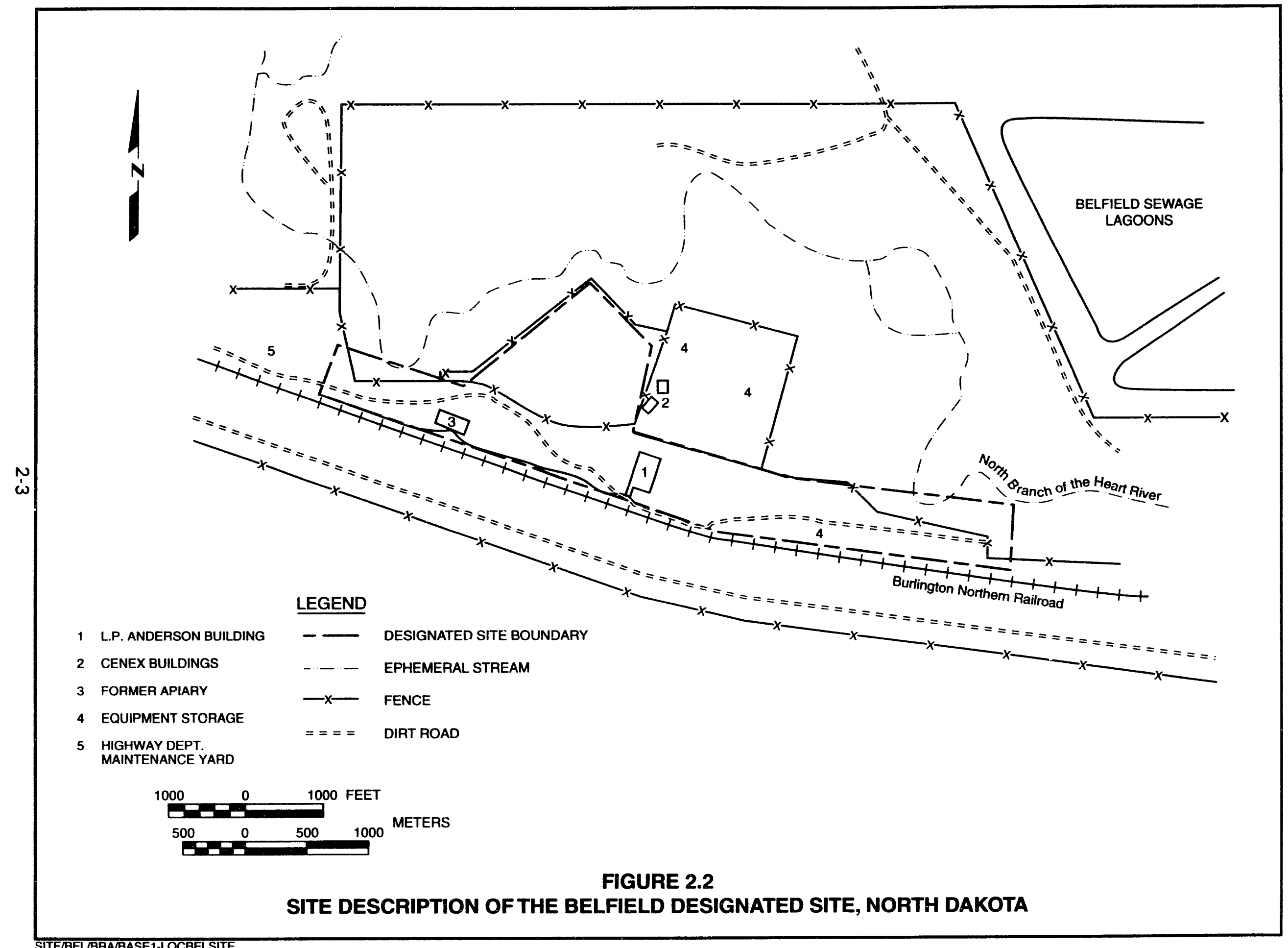


The site was left level with no visible ash pile. Most of the L.P. Anderson and Cenex storage areas were surfaced with $1 \mathrm{ft}(0.3 \mathrm{~m})$ of scoria gravel; native weeds and grasses have vegetated the rest of the site.

Contamination at the site may have resulted from incomplete recovery of ash during lignite combustion, ash cooling, or ash loading onto rail cars. Ash storage or sludge disposal from the rotary kiln scrubber may have also contributed to site contamination. Dispersion of contaminated materials by wind and water erosion has covered 31 ac (13 ha) (DOE, 1990).

\subsection{CLIMATE}

The nearest weather station is in Dickinson, North Dakota, $19 \mathrm{mi}(31 \mathrm{~km})$ east of Belfield. Weather conditions at Dickinson are considered very similar to those at Belfield. Annual temperatures recorded at Dickinson include an average maximum of $54^{\circ}$ Fahrenheit $\left({ }^{\circ} \mathrm{F}\right),\left(12^{\circ} \mathrm{Celsius}\left({ }^{\circ} \mathrm{C}\right]\right)$ and an average minimum of $30^{\circ} \mathrm{F}\left(-1^{\circ} \mathrm{C}\right)$, with extremes of $105^{\circ}$ and $-35^{\circ} \mathrm{F}\left(41^{\circ}\right.$ and $\left.-37^{\circ} \mathrm{C}\right)$ for the 30 years on record. The average annual rainfall is 16 inches $(40$ centimeters [cm]), 80 percent of which falls between April and September; the average annual snowfall is 30 inches $(76 \mathrm{~cm})$. The predominant wind direction is westnorthwest, with an average annual wind speed of $13 \mathrm{mi}(21 \mathrm{~km})$ per hour (DOE, 1993).

\subsection{GROUND WATER}

\subsubsection{Hydrogeology}

Sediments of the Sentinel Butte Formation, the uppermost unit of the Tertiary Fort Union Group, underlie the Belfield processing site. The Sentinel Butte Formation consists of approximately $150 \mathrm{ft}(46 \mathrm{~m})$ of interbedded sandstones, siltstones, claystones, and lignites, which dip eastward at approximately $12 \mathrm{ft} / \mathrm{mi}(2.3 \mathrm{~m} / \mathrm{km})$. Lithologic logs from monitor wells at the Belfield processing site indicate that an interbedded sequence of silty sandstone, sandy claystone, and silty claystone underlies a thin soil cover and is present to a depth of approximately $60 \mathrm{ft}(18 \mathrm{~m})$ (Figure 2.3). This hydrogeologic unit is referred to as the "upper zone" of fine-grained sediments. A lignite unit approximately $15 \mathrm{ft}(4.6 \mathrm{~m})$ thick underlies the upper zone. This hydrogeologic unit is referred to as the "lignite zone." Claystone of undetermined thickness underlies the lignite zone.

Ground water occurs in fine-grained sediments and fractured lignites in the Sentinel Butte aquifer system under unconfined and semiconfined conditions at the Belfield processing site. Water levels range from 15 to $38 \mathrm{ft}(4.6$ to $11.6 \mathrm{~m}$ ) below the land surface. Precipitation and seepage from intermittent streams and standing surface water directly recharge the ground water system in the Belfield site vicinity. There is no evidence of ground water discharge to the land surface or to surface water in the site vicinity. Seasonal fluctuations of the potentiometric surfaces of the upper zone and the lignite zone generally aie 


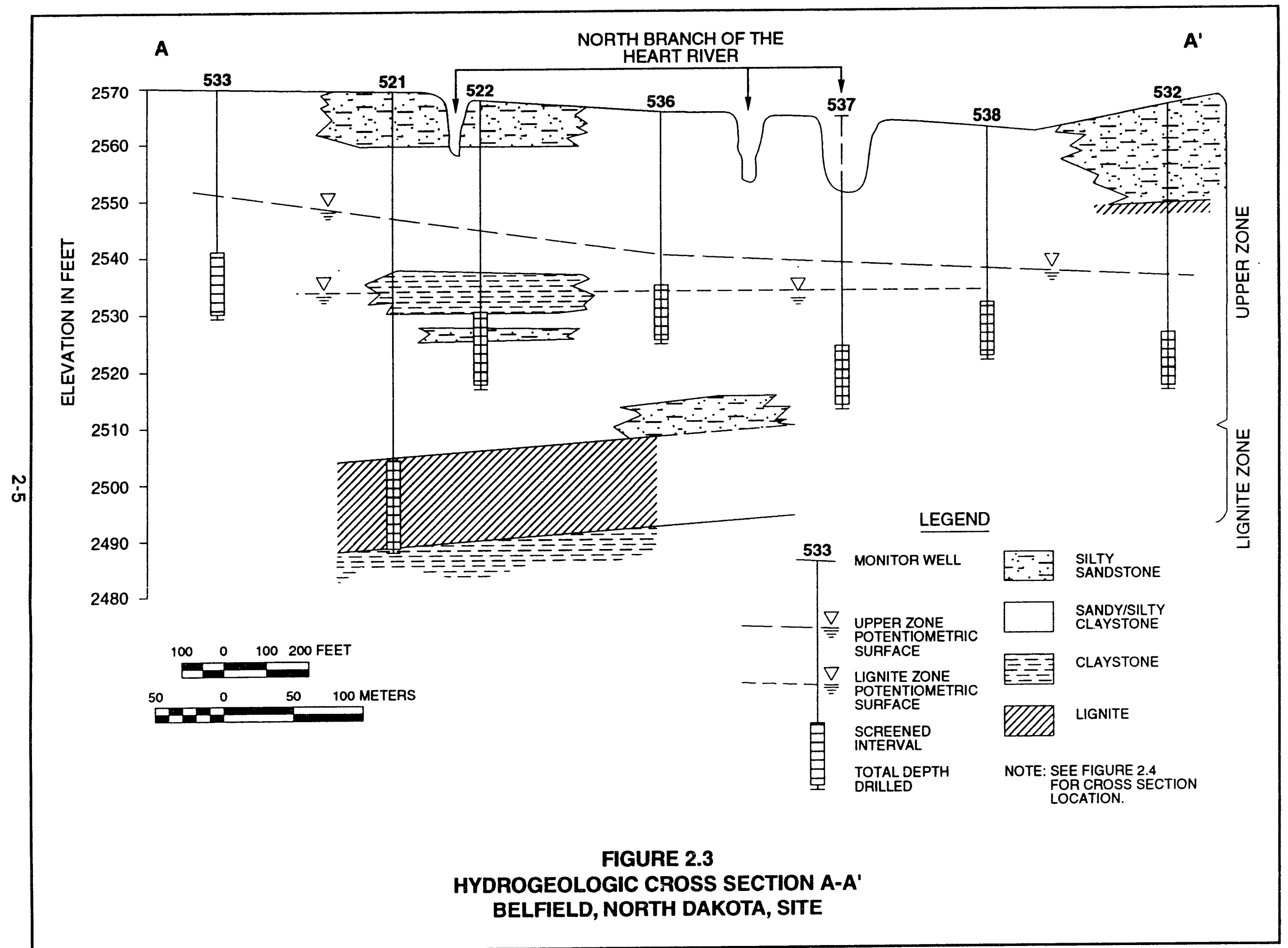


less than $2.5 \mathrm{ft}(0.8 \mathrm{~m})$ (from lowest to highest ground water elevation). These water level fluctuations are in response to spring snowmelt and periods of maximum precipitation during the summer and fall and to variations in the local and regional amounts of annual precipitation.

\subsubsection{Hydraulic characteristics}

Regional ground water in the Sentinel Butte aquifer system flows toward the east. The potentiometric surface in the upper zone beneath the Belfield site indicates that ground water flows toward the south and southeast with an average hydraulic gradient of 0.02 (Figure 2.4). Minor variations in the potentiometric surface may result from the effects of surface water infiltration from the North Branch of the Heart River, seepage from the sewage lagoons northeast of the site, and lateral and vertical differences in the lithology. Any variations would be very local and would not change the overall direction of ground water flow or increase movement of potentially contaminated ground water away from the Belfield site. These influences are evident in 1993 water level measurements (Figure 2.4). Geology and water level data for the area indicate that the upper zone is not a laterally continuous, integrated aquifer unit; rather, it consists of ground water in perched zones and in heterogeneous units with lateral and vertical facies variations. Although there is hydraulic interconnection within the upper zone, there are varying water levels as a result of differential equilibration of water percolating through the zone. The shallow hydraulic gradient and low hydraulic conductivity of the aquifer unit limit the movement of contamination by reducing ground water flow.

The potentiometric surface in the lignite zone beneath the Belfield site indicates that the ground water generally flows toward the east with an average hydraulic gradient of 0.0004 (Figure 2.5). The hydraulic gradient in the lignite zone is low because of low topographic relief in the area and relatively higher transmissivity in the fractured lignite, which facilitates equilibration of water levels. The vertical hydraulic gradient in the total aquifer system is downward toward the lignite zone.

An average hydraulic conductivity of $0.7 \mathrm{ft} /$ day $13 \times 10^{-4}$ centimeters per second $[\mathrm{cm} / \mathrm{s}]$ ) was calculated for the upper zone based on data from slug tests conducted in monitor wells. An average transmissivity of $570 \mathrm{ft}^{2} /$ day $\left(6.2 \mathrm{~cm}^{2} / \mathrm{s}\right)$ was calculated for the lignite zone based on data from an aquifer pumping test conducted in monitor well 521. Assuming equally transmissive characteristics throughout the lignite zone and a saturated thickness of $17 \mathrm{ft}$ $(5.2 \mathrm{~m})$, the average hydraulic conductivity of the lignite zone would be $34 \mathrm{ft} /$ day $\left(1.2 \times 10^{-2} \mathrm{~cm} / \mathrm{s}\right)$.

The average linear ground water velocity for the upper zone is $0.07 \mathrm{ft} / \mathrm{day}$ $\left(2.5 \times 10^{-5} \mathrm{~cm} / \mathrm{s}\right)$, based on an average hydraulic conductivity of $0.7 \mathrm{ft} / \mathrm{day}$ $\left(2.5 \times 10^{-4} \mathrm{~cm} / \mathrm{s}\right)$, an average hydraulic gradient of 0.02 , and an estimated effective porosity of 0.20 . The average linear ground water velocity for the lignite zone is $0.27 \mathrm{ft} /$ day $\left(9.6 \times 10^{-5} \mathrm{~cm} / \mathrm{s}\right)$, based on an average hydraulic 


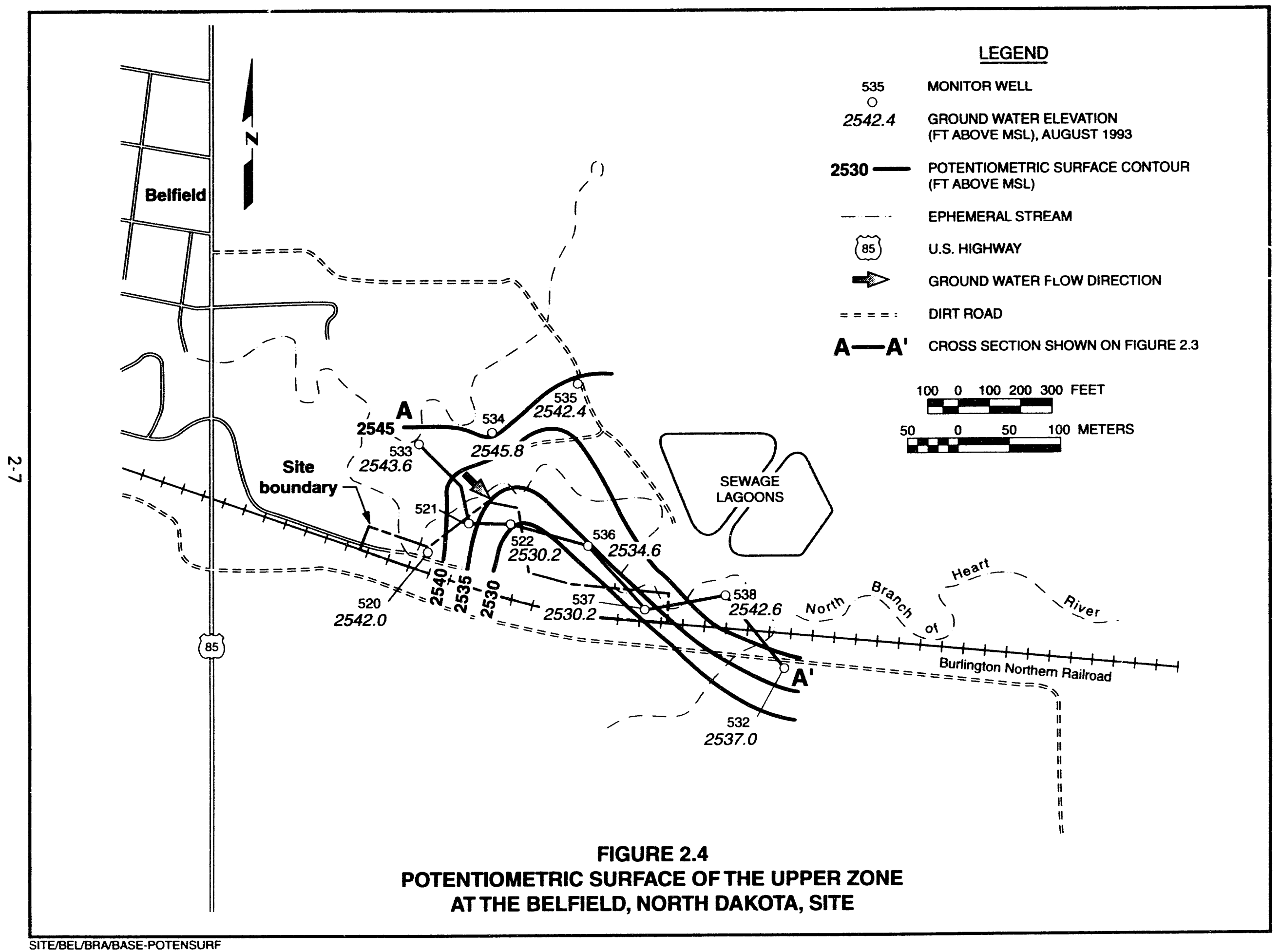




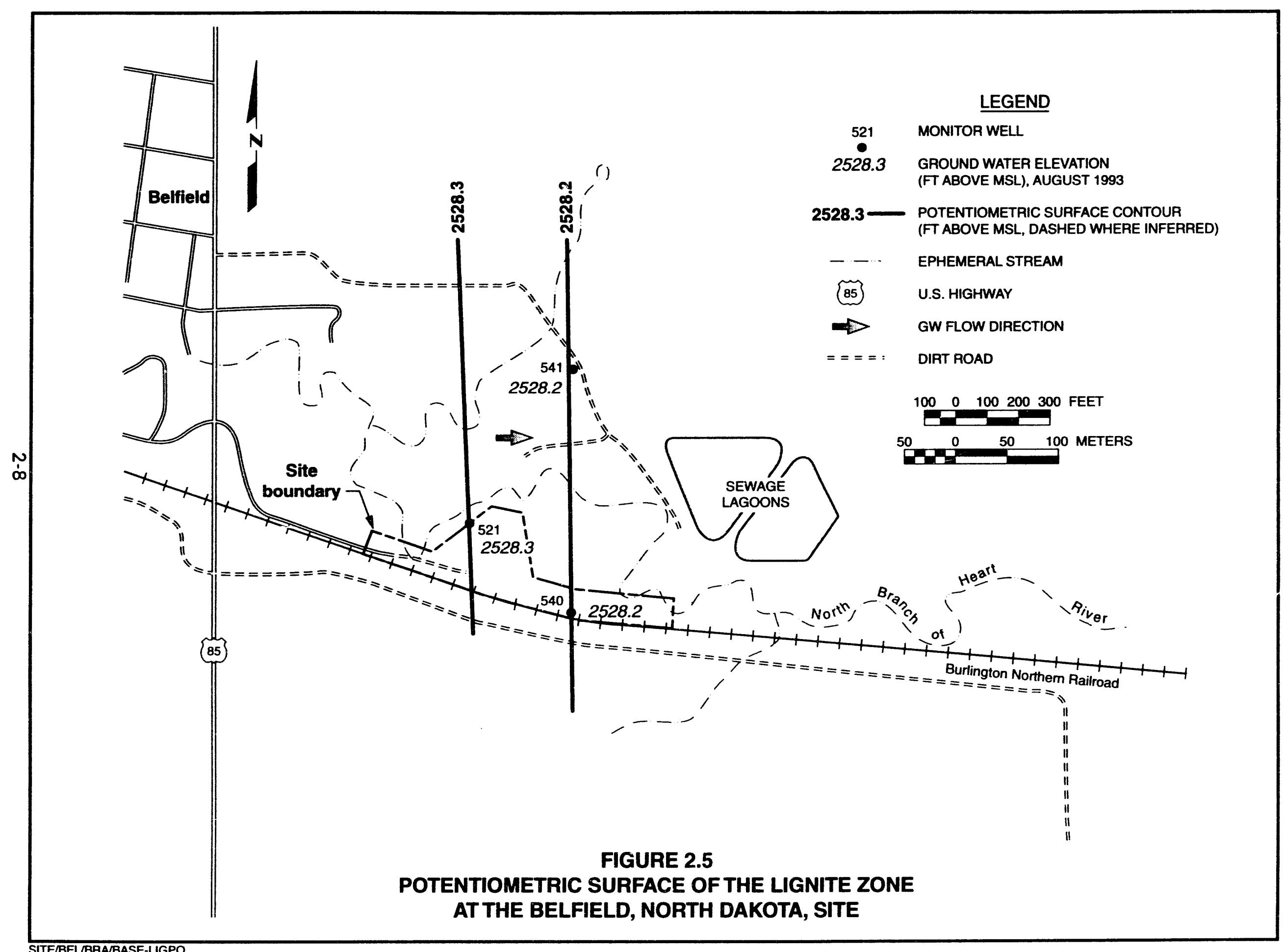


conductivity of $34 \mathrm{ft} /$ day $\left(1.2 \times 10^{-2} \mathrm{~cm} / \mathrm{s}\right)$, an average hydraulic gradient of 0.0004 , and an estimated effective porosity of 0.05 .

\subsubsection{Ground water monitoring}

Ground water samples have been collected from DOE monitor wells at the Belfield processing site from 1986 through 1988 and in 1993 and analyzed for inorganics (Figure 2.6). Water sample analyses from DOE monitor wells 533, 534,535 , and 539 were used to determine background ground water quality in the upper zone. Water sample analyses from DOE monitor wells 520, 522, $532,536,537$, and 538 were us $9 d$ to assess on-site and downgradient ground water quality in the upper zone. Water sample analyses from monitor wells 521,540 , and 541 were used to determine ground water quality in the lignite zone. Background ground water quality defined in the lignite zone is represented by monitor well 541.

Several domestic wells in the processing site vicinity were also sampled during these times (Figure 2.6). Data from specific domestic wells $(525,527$, and 528) were used qualitatively to support characterization of background water quality in the upper zone.

\subsection{SURFACE WATER}

\subsubsection{Surface water hydrology}

The Belfield site is in the Missouri Plateau of the northern Great Plains physiographic province. The region is drained by the Missouri River, which flows eastward through the center of the Williston Basin. The terrain in the site vicinity consists of gently rolling grassland.

The site is just south of the North Branch of the Heart River, an intermittent stream that generally flows from west to east in a channel 10 to $15 \mathrm{ft} / 3$ to $5 \mathrm{~m}$ ) below the general site elevation. The river flows primarily during spring runoff and after heavy rainfall. For the remainder of the year, stagnant water ponds at low points in the channel. Runoff in the site area either drains to the river or ponds on the site. Runoff from surrounding areas reaches the site from the west and east. Runoff from the north drains into the Heart River; the railroad tracks south of the site prevent runoff from the south from entering the site. There is no evidence of severe erosion in the site area caused by recent runoff from snowmelt or precipitation.

\subsubsection{Surface water monitoring}

Filtered surface water samples were collected along the North Branich of the Heart River in the vicinity of the processing site from sampling locations 529 , $530,546,547$, and 548. These samples were analyzed for a full suite of inorganic parameters in 1986, 1987, and 1988 (Figure 2.7). Data for these 


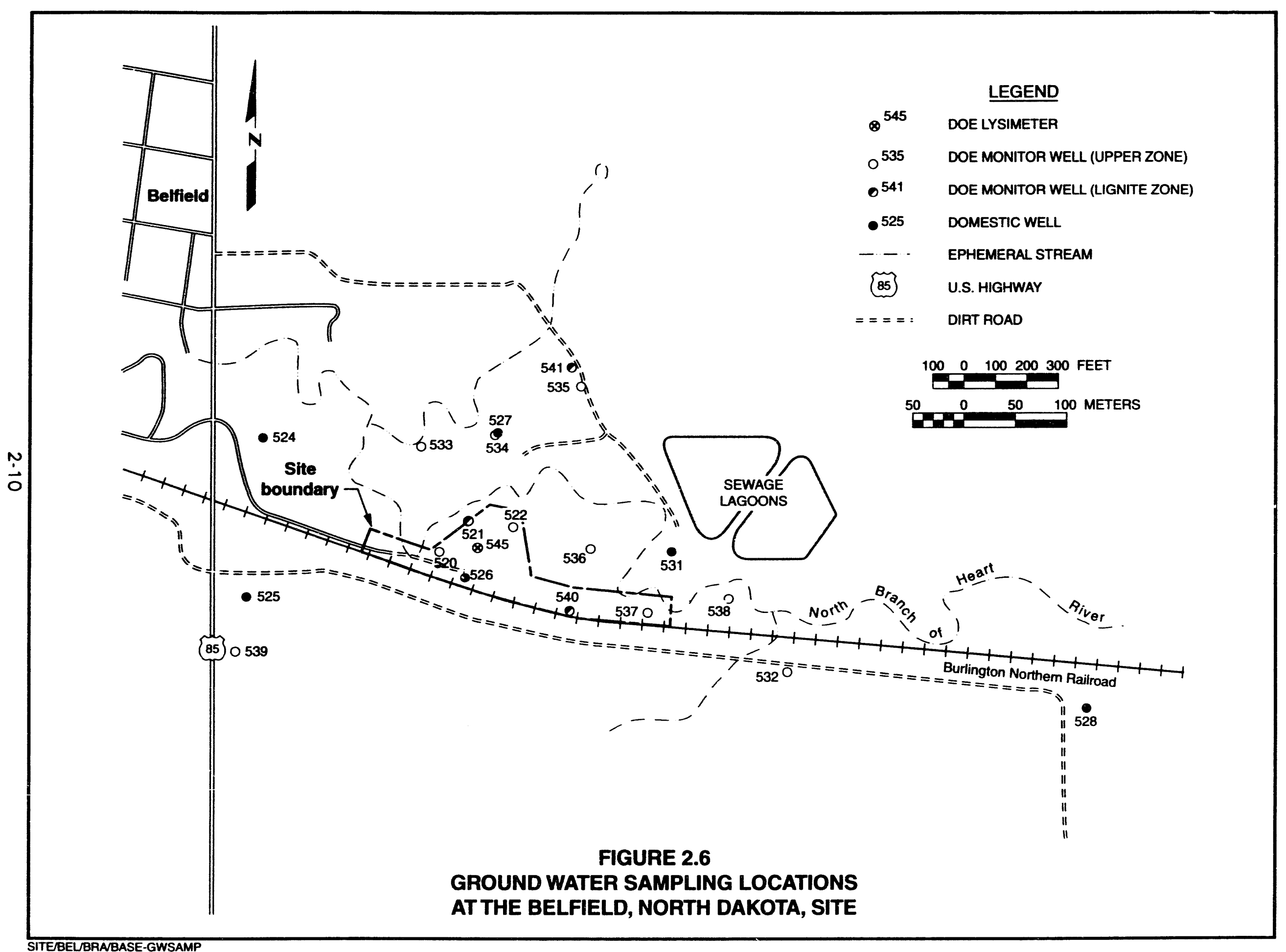




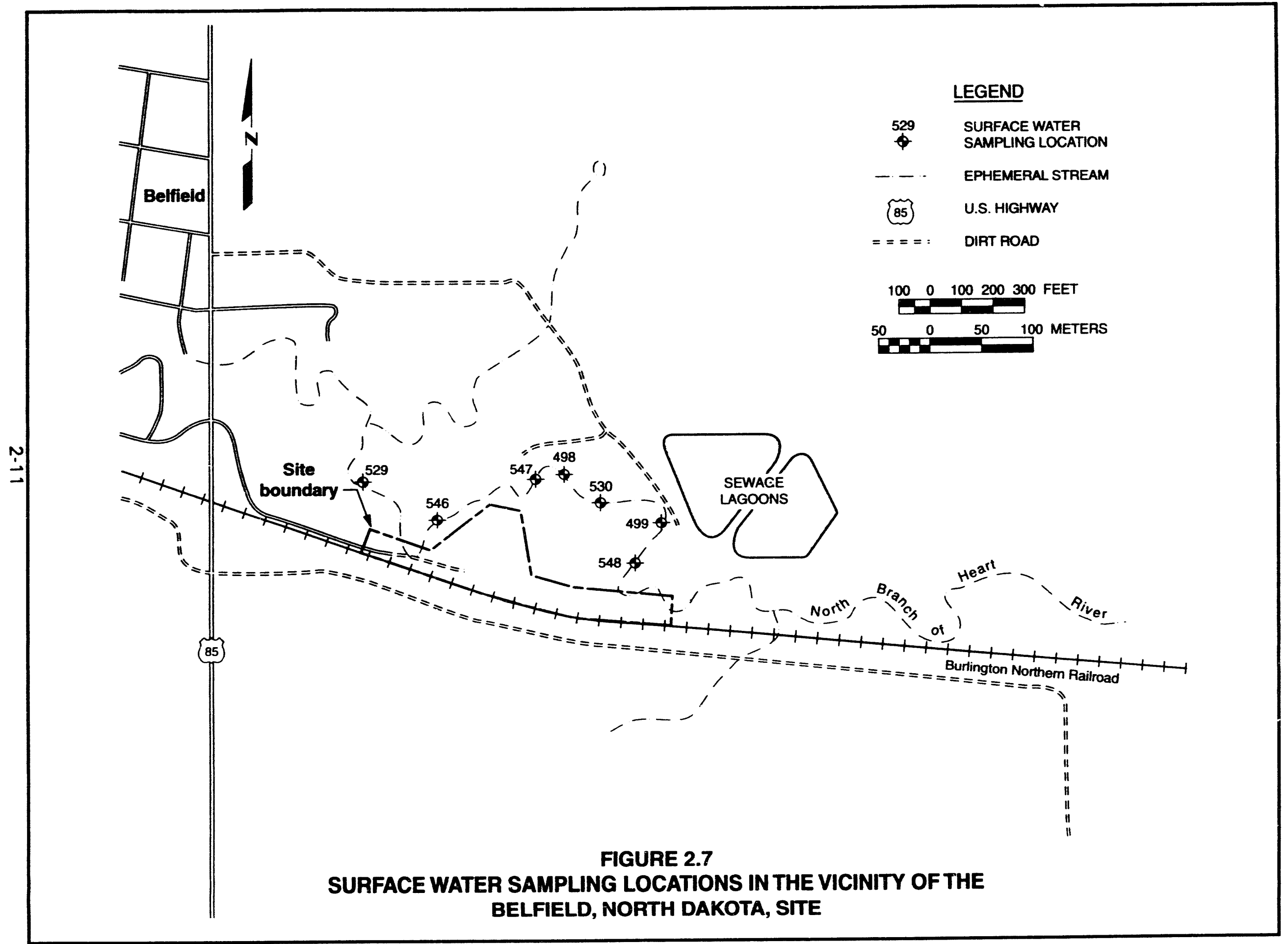


sampling locations are summarized in Table 3.6 and were used to characterize surface water quality.

Unfiltered surface water and surficial sediment samples 10 to 4 inches 10 to $10 \mathrm{~cm}])$ were collected from the North Branch of the Heart River on November 4, 1993, in the site vicinity (sampling locations 529,530,498, and 499) (Figure 2.7). These surface water and sediment samples were analyzed for total chromium, molybdenum, selenium, and uranium. These analyses showed equivalent results to the filtered surface water quality data. No further assessment of the unfiltered surface water data is incorporated into the characterization of surface water quality.

\section{$2.5 \quad$ LAND USE}

Stark Cnunty, including land around the Belfield site, is similar to other counties in southwestern North Dakota where land is privately owned and used mainly for agriculture. One-half mile $(0.8 \mathrm{~km})$ northwest of tive site, across Highway 85, is the town of Belfield. Two large city sewage layoons are located approximately $0.5 \mathrm{mi}(0.8 \mathrm{~km})$ northeast of the site, just across the river (Figure 2.8).

The designated site and the land immediately surrounding it are privately owned and are currently used for light industrial purposes, such as equipment maintenance and storage. Within the site boundary are four buildings: one building is the former apiary; two small cinder block buildings are leased by the CENEX drilling mud company; and the fourth building is leased by the L.P. Anderson Company (Figure 2.2). In the past, these buildings were used for miscellaneous equipment maintenance and storage; however, they have recently been abandoned.

The Burlington Northern Railroad maintains an easement along the railroad tracks on the southern site boundary. Immediately west of the site is an active storage and maintenance yard for the North Dakota State Highway Department, where trucks and equipment are parked and road sand is stockpiled.

Declines in the oil industry starting in 1982 severely hit the town of Belfield. Belfield's population decreased approximately 50 percent between 1982 and 1990. Populations for most towns in this part of the North Dakota do not exceed several thousand. A 1990 census recorded 887 residents in the town of Belfield. The resident population consists of people who own land and farm or who own small businesses in town. The population of Stark County is 22,832 .

\subsection{WATER USE}

Residents in the Belfield area receive water from a local municipal water supply system. The water system is supplied from several deep wells (more than $1000 \mathrm{ft}(300 \mathrm{~m}]$ deep) located within a mile south of town. 


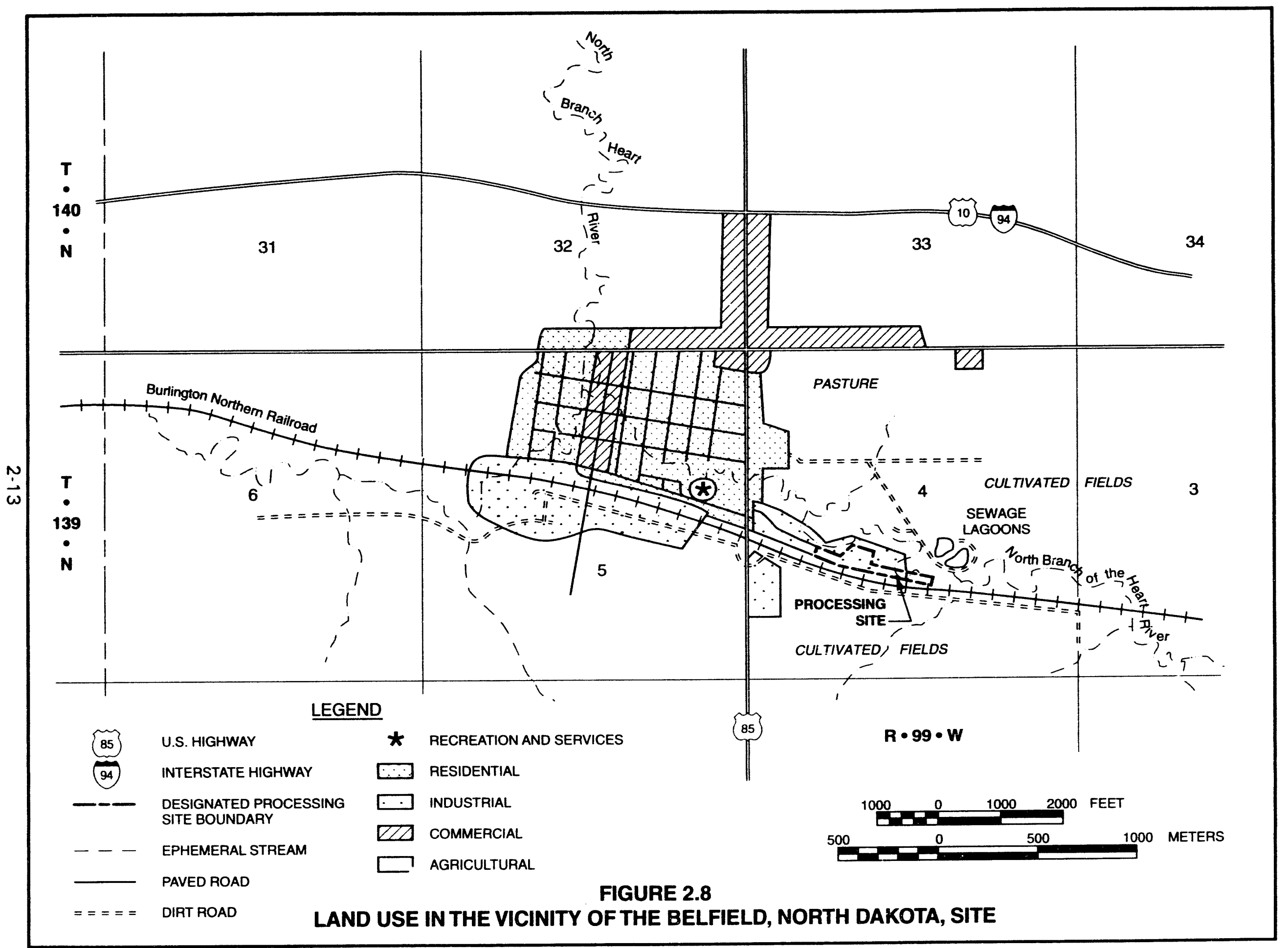


Currently, ground water is the main water source for this region of North Dakota. Access to and private use of shallow ground water in the site vicinity was the concern for this risk assessment. The DOE investigated the extent of water use and the number of privately owned shallow wells through site visits, discussions with landowners, and historic records. Seven private domestic wells were identified within $1.0 \mathrm{mi}(1.6 \mathrm{~km})$ of the processing site. These domestic wells were sampled as part of the DOE UMTRA Project ground water monitoring program (Figure 2.6). In 1993, the Stark County Plat Book and Directory was reviewed to identify any additional domestic wells within a 2-mi $(3-\mathrm{km})$ radius of the Belfield site. No additional domestic wells were identified for sampling and analyses.

Common uses for shallow ground water in the site vicinity are washing clothes, flushing toilets, watering gardens, and watering livestock. Shallow ground water is not commonly used for drinking. Ready access to the municipal water supply system and the variable nature of water quality in the shallow aquifer, along with unreliable yields, make it a poor water source of choice. However, nne residence was found to be using three shallow domestic wells exclusively for all its residential water needs, one of which is DOE monitor well 528.

Well 528 is about $1 \mathrm{mi}(1.6 \mathrm{~km})$ southeast of the processing site, just south of the railroad tracks. This shallow well $(51 \mathrm{ft}[15 \mathrm{~m}])$ is a residence water supply used for all domestic purposes, including drinking, cooking, bathing, cleaning, and gardening. Data exist for this well for 1986, 1987, 1988, and 1993. The two other shallow wells at this property are used to water livestock but were not sampled.

The Hiebechuck Construction Company, located along Highway 85 northwest of the site, owns domestic well 524. This deep well (approximately $350 \mathrm{ft}$ [107 m]) provides water to a residence shop for the work area sink. Water is used for the toilet and for cleaning, not specifically for drinking. However, the location and easy access to water from this well create the potential for drinking the water. This well is upgradient of the site and is unlikely to be affected by the site. The DOE has sampling data for this well for 1986, 1987, 1988, and 1993.

Domestic well 525 feeds an outside water faucet at a small building located along Highway 85 east of the processing site. The building use is not known, but past discussions with occupants have determined that its water is from: a shallow well and is used inside the building for flushing the toilet and for cleaning. During the 1993 summer sampling round, this building appeared abandoned. However, the potential exists for this water to be used for drinking. This well previously was sampled in 1986, 1987, and 1988.

Domestic well 527, located north of the site across the river, was sampled in 1986, 1987, and 1988. Sampling was not possible in 1993, because the cap was found sealed. Ownership of this well is uncertain. This well is believed to be $80 \mathrm{ft}(24 \mathrm{~m})$ deep. Water quality data from this well were not used to 
assess local water quality because of the lack of recent sampling data and lack of valid well completion information.

Domestic well 526 supplies the L.P. Anderson building located inside the processing site boundary. The $75-\mathrm{ft}(23-\mathrm{m})$-deep well feeds the inside and outside faucets and is used for the toilet and utility sink. It is not known to be used for drinking; however, the potential exists due to its accessibility. During the 1993 sampling round, the building appeared abandoned and the well was not íunctional.

Domestic well 531 feeds a stock watering tank near the processing site, east of the river. This 60-ft (18-m)-deep well was sampled in 1986, 1987, and 1988. This well is no longer functional, and no samples were collected during the 1993 sampling round. 


\subsection{EXTENT OF CONTAMINATION}

Lignite ashing operations conducted at the Belfield site involved only combustion of organic material; no chemical, metallurgical, or nuclear processes were involved. A completely enclosed ashing circuit and a scrubber system on the stack reduced potential airborne contamination. However, the UMTRA Surface Project has identified soil contamination to a depth of $3 \mathrm{ft}(1 \mathrm{~m})$ below existing grade at the Belfield processing site (DOE, 1990). Surface contamination also extends outside the designated site boundary (Figure 3.1). Ground water contamination may have occurred through leaching of the surface contamination or historic leaching of the raw ore during storage on the site. Trace elements associated with metalliferous lignite might therefore be expected in ground water. Surface contamination may have also affected surface water in the vicinity of the site.

Potentially contaminated ground water at the Belfield site consists of an upper zone of sandy clay and a deeper lignite zone (Section 2.3.1). In the site region, there is a downward hydraulic gradient from the upper zone into the lignite zone, which means the lignite zone is recharged by precipitation and receives downward flow from the upper zone. Consequently, any contamination in the upper zone has the potential to migrate into the lignite zone. Ground water hydrology in the vicinity of the Belfield site is discussed in more detail in Section 2.3.

Filtered ground water samples from DOE monitor wells and domestic wells in the Belfield site vicinity were collected in 1986, 1987, 1988, and 1993 and analyzed for a full suite of inorganic parameters. One round of nonfiltered ground water samples was collected in 1993. DOE and domestic monitor well locations are shown in Figure 2.6. Table 3.1 presents monitor well information. Surface water monitoring is discussed in Section 2.4.2.

Water quality data for filtered samples were used to characterize the extent of ground water contamination, surface water contamination, and the geochemical processes active at the site and to distinguish the contaminants of potential concern for human health and the environment. On-site water quality in the upper zone and lignite zone was compared to background water quality in each zone. Data for DOE monitor wells were used quantitatively, while data for existing domestic wells were used qualitatively, in the assessment of water quality. Information on well construction of domestic wells was insufficient to allow combining the two data sets.

Data for the southwest region of North Dakota are available from the literature and were reviewed for comparison to the assessment of background water quality in the site vicinity. The main objective of this risk assessment is to determine the potential risks due to ground water contamination attributable to the processing site. Water quality at the site was characterized and compared to background levels to select specific contaminants of potential concern to human health. 


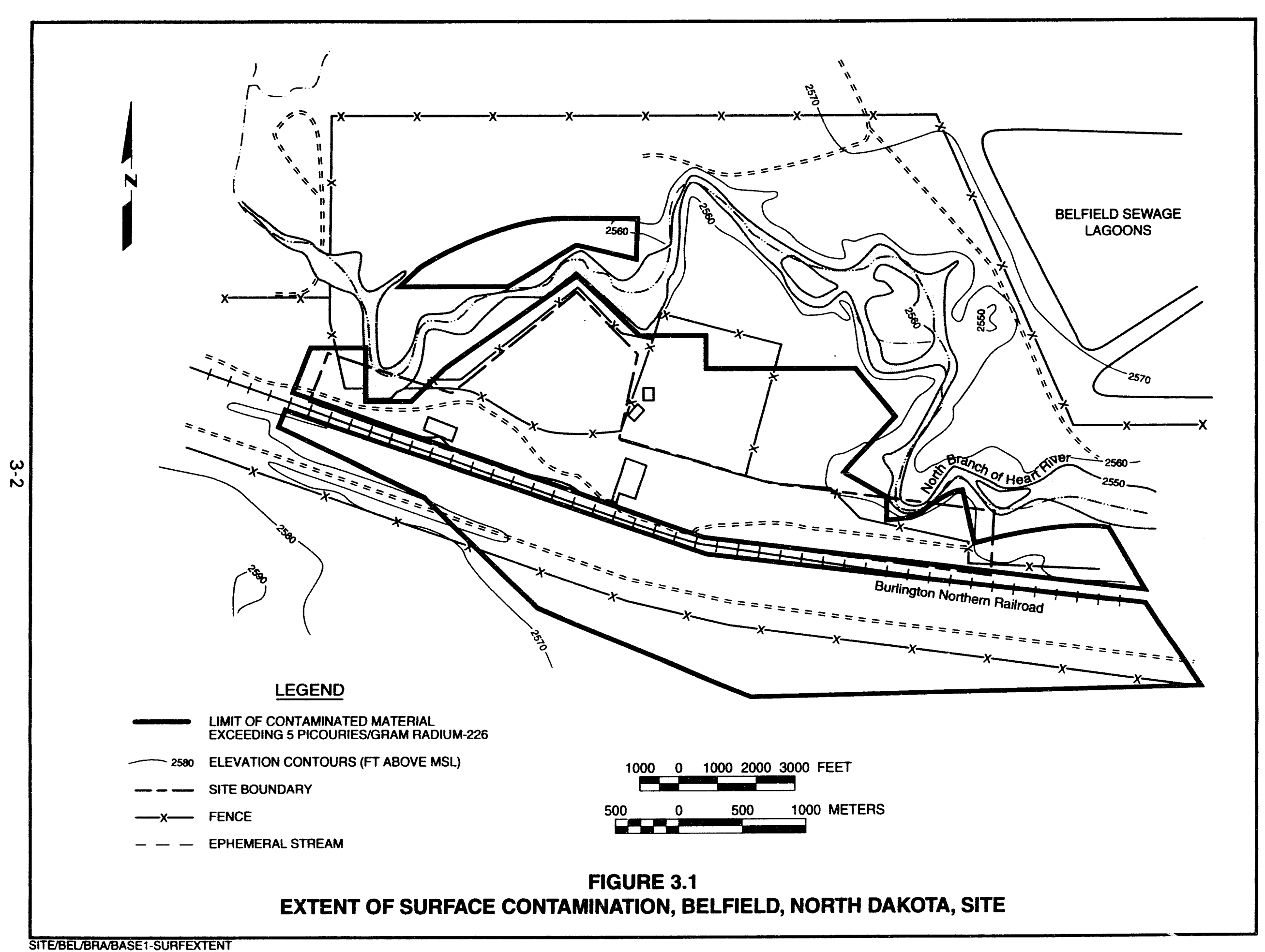


Table 3.1 Monitor well information for the Belfield, North Dakota, site

\begin{tabular}{|c|c|c|c|}
\hline \multirow[b]{2}{*}{ Location ID } & \multicolumn{2}{|c|}{$\begin{array}{c}\text { Screened interval } \\
\text { (below land surface) }\end{array}$} & \multirow[b]{2}{*}{ Hydrogeologic zone } \\
\hline & ft & m & \\
\hline \multicolumn{4}{|l|}{ DOE monitor wells } \\
\hline 520 & $32-42$ & $10-13$ & Upper zone \\
\hline 521 & $64-82$ & $20-25$ & Lignite zone \\
\hline 522 & $37-52$ & $11-16$ & Upper zone \\
\hline 532 & $40-50$ & $12-15$ & Upper zone \\
\hline $533^{a}$ & $29-39$ & $8-12$ & Upper zone \\
\hline $534^{a}$ & $30-40$ & $9-12$ & Upper zone \\
\hline $535^{a}$ & $35-50$ & $11-15$ & Upper zone \\
\hline 536 & $30-40$ & $9-12$ & Upper zone \\
\hline 537 & $40-50$ & $12-15$ & Upper zone \\
\hline 538 & $30-40$ & $9-12$ & Upper zone \\
\hline $539^{a}$ & $49 \cdot 59$ & $15-18$ & Upper zone \\
\hline 540 & $59-69$ & $18-21$ & Lignite zone \\
\hline 541 & $65-80$ & $20-24$ & Lignite zone \\
\hline \multicolumn{4}{|l|}{ Domestic wells ${ }^{b}$} \\
\hline 524 & \multicolumn{2}{|c|}{ UK } & Below lignite \\
\hline $525^{a}$ & \multicolumn{2}{|c|}{ UK } & Upper zone \\
\hline 526 & \multicolumn{2}{|c|}{ UK } & Lignite zone \\
\hline 527 & \multicolumn{2}{|c|}{ UK } & Lignite zone \\
\hline $528^{a}$ & \multicolumn{2}{|c|}{ UK } & Upper zone \\
\hline 531 & \multicolumn{2}{|c|}{ UK } & Upper zone \\
\hline
\end{tabular}

a Wells used to determine background ground water quality in the upper zone.

b Geologic unit is estimated based on limited information on well depth.

UK-unknown. 


\subsection{BACKGROUND GROUND WATER QUALITY DATA SUMMARY}

\subsubsection{Regional background ground water quality}

Shallow ground water quality in southwestern North Dakota is characterized by elevated trace elements and total dissolved solids (TDS), which are thought to be associated with metalliferous lignites in sediments of the Fort Union Group. Trace elements such as uranium, vanadium, cadmium, molybdenum, chromium, arsenic, selenium, and antimony are commonly associated with lignite in southwestern North Dakota (Miller and Given, 1986; Roberts, 1994; Zeller and Schopf, 1959; Karner et al., 1986; Duel and Annell, 1956; Moore et al., 1959; Nobel, 1972). Major ions, including calcium, sodium, and magnesium, also are associated with lignites and associated sediments (Miller and Given, 1986; Fulton and Jones, 1986; Fulton, 1989; Karner et al., 1986; Ting and Jones, 1986). These trace elements and major ions are thought to bind to humic matter through carboxylic and other chelated coordination complexes (Denson et al., 1959; Miller and Given, 1986; Karner et al, 1986) and undergo ion exchange reactions in ground water (Karner et al, 1986; Miller and Given, 1986). Furthermore, Houghton et al. (1987) observed that sediments above a lignite seam in the Sentinel Butte member of the Fort Union Formation in Stark County contained elevated uranium that appeared to be more mobile than uranium in the lignite. This evidence suggests that exchangeable ions and trace elements in lignites and associated sediments may control ground water chemistry and, therefore, explains the presence of trace elements in shallow ground water in southwestern North Dakota.

Much of the region is underlain by the Sentinel Butte member of the Fort Union Formation, which contains lignite beds and other carbonaceous material. Trace elements, like uranium, appear concentrated in and adjacent to lignite-bearing zones, which modify ground water as it is recharged by infiltrating precipitation. Roberts (1994) has collected and interpreted data on uranium concentrations in shallow ground water in southwestern North Dakota and in the Belfield site vicinity. Out of 53 ground water sar.ples from Stark County with an average well depth of $70 \mathrm{ft}(21 \mathrm{~m}), 13$ ground water samples had uranium concentratiore greater than 0.02 milligrams per liter $(\mathrm{mg} / \mathrm{L})$ and 6 had uranium concentrations $y$ ater than $0.10 \mathrm{mg} / \mathrm{L}$. The average uranium concentration in ground water accessed by these wells was $0.054 \mathrm{mg} / \mathrm{L}$ (Roberts, 1994). Roberts (1994) also has interpreted historical water quality data from 467 locations in southwestern North Dakota. The data showed an average uranium concentration of $0.018 \mathrm{mg} / \mathrm{L} ; 106$ samples were more than $0.023 \mathrm{mg} / \mathrm{L}$; and 11 were more than $0.10 \mathrm{mg} / \mathrm{L}$. Uranium appears widespread in shallow ground water in this region of North Dakota.

\subsubsection{Background ground water quality in the Belfield site vicinity}

Background ground water quality in the Belfield site vicinity varies with depth and lithology, suggesting the presence of three distinct hydrochemical zones in the shallow ground water system. The first hydrochemical zone, located in 
sandy claystone, is characterized by relatively low trace elements, elevated alkalinity, and TDS, with sodium, sulfate, and carbonate as the major ions. Background monitor wells screened in this water quality zone include domestic well 525 and DOE monitor wells 535 and 539. The second hydrochemical zone, located immediately above lignite, is physically characterized by discontinuous stringers of lignite interbedded with sandy claystone. Ground water quality in this zone is elevated in trace elements such as vanadium, uranium, antimony, chromium, and molybdenum, with calcium and sulfate as the major ions. The background wells screened in this water quality zone are domestic well 528 and DOE monitor well 534. These two hydrochemical zones make up the "upper zone." The third hydrochemical zone is located in the continuous lignite seam (lignite zone) beneath the site. Ground water chemistry in this zone generally is characterized by low trace element concentrations (excluding antimony and molybdenum), low alkalinity, and elevated strontium, with calcium, magnesium, and sulfate as the major ions. Background monitor wells screened in this water quality zone include domestic well 527 and DOE monitor well 541.

The distribution of trace elements in the subsurface at background locations around the Belfield site appears to fit the following conceptual model. As oxidizing precipitation infiltrates into the subsurface, trace elements are leached from the sediments in the upper aquifer zone, above the lignite (hydrochemical zones one and twol. Trace elements appear to be more mobile in hydrochemical zone two because of the secondary porosity of the lignite stringers, which act as both a source and sink for metals and trace elements. As ground water eventually flows downward into the lignite zone (hydrochemical zone three). most trace elements complex with the lignite and thus are attenuated from ground water.

\section{Upper zone}

For this risk assessment, water quality in the upper zone was characterized by both hydrochemical zones one and two. Well completion information was insufficient to distinguish exactly which wells were screened in which hydrochemical zone. In addition, some mixing of waters from hydrochemical zones one and two is expected. Therefore, background water quality in the upper zone combines well data characteristic of both zones. Based on the discussion of regional water quality in Section 3.1.1, this definition of background water quality is reasonable and will not decrease the ability to detect site-related contamination.

Given the varying hydrochemical conditions in the upper zone, background water chemistry exhibits a great deal of variation among wells. Overall, wells 534 and 528 are similar, as are wells 525, 535, and 539. Well 533 lies somewhere between the two groupings. Wells 534 and 528 have lower alkalinity and $\mathrm{pH}$, higher concentrations of TDS, and higher concentrations of metals, including uranium, than wells 525,535 , and 539 . 
DOE monitor wells $533,534,535$, and 539 quantitatively represent background water quality in the site vicinity for comparison to on-site water quality. The domestic well data were not incorporated quantitatively in the comparison because of the uncertainties regarding their construction. However, the similarity between well 534 and domestic well 528, far downgradient of the site, demonstrates that relatively high concentrations of trace elements and metals may occur naturally in shallow ground water in the region.

\section{Lignite zone}

Background ground water quality for the lignite zone is represented by DOE monitor well 541 located north and hydraulically crossgradient/upgradient of the site. Water quality data from this well showed low concentrations of TDS and alkalinities in the 400- to $600-\mathrm{mg} / \mathrm{L}$ range. Several trace metals were detected in the lignite background, including uranium, vanadium, aluminum, selenium, molybdenum, chromium, and antimony. Uranium and antimony concentrations in the lignite background are much lower than in the upper zone, while vanadium, aluminum, selenium, molybdenum, and chromium concentrations are roughly comparable to background in the upper zone. Domestic well 527, also located north and hydraulically crossgradient/upgradient of the site, showed similar results, which supported the assessment of background water quality.

\subsection{MAGNITUDE OF SITE-RELATED GROUND WATER CONTAMINATION}

Potential sources of contamination in ground water at the Belfield processing site resulting from the lignite processing operations include the following:

- Leaching of water from stockpiled raw lignite prior to ashing.

- Ash and dust potentially released to the atmosphere during different phases of the process; wind and erosional dispersion and subsequent leaching of this surface contamination.

- Leaching of water through sludges and residues created from the stack gas-scrubber.

Lignite burning was the only process conducted at the Belfield site. Metals associated with lignite, such as uranium, vanadium, chromium, lead, mercury, selenium, antimony, molybdenum, silver, and other ions, are expected in ground water. The presence of organics was not investigated. Any non-ore-related contaminants found in ground water, such as nitrate, phosphate, and chloride, most likely were introduced by other industrial or agricultural activities in the site vicinity.

Soil pore fluid collected from DOE suction lysimeter 545 contained elevated concentrations of molybdenum, nitrate, selenium, chromium, and uranium. With the exception of nitrate, contamination in the unsaturated zone probably is 
derived from the lignite ashing process. Nitrate concentrations could be related to ongoing agricultural and waste water practices adjacent to the site.

\subsubsection{Site-related contamination in the upper zone}

Contaminants in ground water do not appear to form a discrete plume in the upper zone downgradient from the processing site but appear concentrated in areas generally beneath and adjacent to the portion of the processing site where the ashing kiln and lignite stockpile were located. This is reasonable considering the diffuse nature and small volume of contaminant source material related to the lignite ashing process.

Ground water contamination appears highest in monitor well 520, located in the vicinity of the former raw lignite storage pile. Ground water reached by well 520 has higher levels of most constituents related to the ashing process. Noticeably lower levels were observed in other on-site and downgradient wells. Well 520 also has a higher frequency of detectable levels of trace metals. The higher levels of TDS would be attributable to the oxidation and liberation of metals associated with lignite during the ashing process. Based on the higher concentrations of uranium and other potentially lignite-related constituents, well 520 was selected to quantify maximum on-site contamination. Table 3.2 summarizes water quality data from well 520 and compares it to background water quality. Furthermore, a data summary of other DOE monitor wells in the vicinity of well $520(522,532,536,537$, and 538$)$ is provided to demonstrate that contamination is localized around well 520. These downgradient and crossgradient wells show similar results to background levels and do not indicate contaminant migration.

Uranium concentrations in DOE monitor wells 520,522 , and 536 exhibit a statistically significant increasing trend with time between 1986 and 1993 (Figure 3.2). The trend is subtle, with an average increase of only $0.004 \mathrm{mg} / \mathrm{L}$ per year, and the cause of the trend is inconclusive. The potential effects of this trend on the risk analysis were taken into account in estimating intake.

Domestic well 531 has elevated levels of several constituents not characteristic of the ashing process. Mounding from the nearby sewage lagoon modifies ground water flow and likely prevents site-related contamination from migrating into this region. Maximum concentrations of ammonium as organic nitrogen (likely from human and animal waste) $(2868 \mathrm{mg} / \mathrm{L}$ ), and alkalinity (likely from the oxidation of organic matter) $(177 \mathrm{mg} / \mathrm{L})$ were measured in ground water from this well. This contamination is probably associated with the nearby sewage lagoons.

Many of the constituents detected in ground water at the site, although potentially attributable to the ashing process, were further evaluated for their occurrence in background water quality and contribution to health risks. The 
Table 3.2 Summary of filtered ground water quality data in the upper zone at Belfield, North Dakota (1986-1993)

\begin{tabular}{|c|c|c|c|c|}
\hline \multirow[b]{3}{*}{ Parameter } & \multirow{3}{*}{$\begin{array}{l}\text { Frequency of } \\
\text { detection a }\end{array}$} & \multicolumn{3}{|c|}{ Observed concentrations } \\
\hline & & Minimum & Median ${ }^{\mathbf{b}}$ & Maximum \\
\hline & & & $\mathrm{mg} / \mathrm{L}$ & \\
\hline \multicolumn{5}{|c|}{ Inorganic parameters } \\
\hline \multicolumn{5}{|l|}{ Aluminum ${ }^{\mathrm{C}}$} \\
\hline Background $^{d}$ & $11 / 15$ & 0.04 & 0.10 & 0.28 \\
\hline Plume $(520)^{e}$ & $4 / 5$ & $<0.10$ & 0.26 & 0.31 \\
\hline Other ${ }^{4}$ & $17 / 21$ & 0.02 & 0.10 & 0.33 \\
\hline \multicolumn{5}{|l|}{ Ammonium } \\
\hline Background & $10 / 15$ & $<0.1$ & 0.3 & 1.4 \\
\hline Plume (520) & $0 / 4$ & $<0.1$ & - & $<0.1$ \\
\hline Other & $11 / 20$ & $<0.1$ & 0.2 & 1.5 \\
\hline \multicolumn{5}{|l|}{ Antimony } \\
\hline Background & $11 / 13$ & $<0.01$ & 0.017 & 0.087 \\
\hline Plume (520) & $3 / 4$ & $<0.003$ & 0.013 & 0.019 \\
\hline Other & $13 / 18$ & $<0.003$ & 0.007 & 0.051 \\
\hline \multicolumn{5}{|l|}{ Arsenic } \\
\hline Background & $11 / 17$ & $<0.001$ & 0.003 & 0.021 \\
\hline Plume $(520)$ & $4 / 6$ & 0.002 & 0.003 & 0.007 \\
\hline Other & $12 / 24$ & $<0.001$ & $\cdot$ & 0.006 \\
\hline \multicolumn{5}{|l|}{ Barium } \\
\hline Background & $7 / 15$ & $<0.01$ & $\cdot$ & 0.02 \\
\hline Plume (520) & $4 / 5$ & 0.03 & 0.04 & 0.10 \\
\hline Other & $11 / 20$ & $<0.01$ & 0.02 & 0.20 \\
\hline \multicolumn{5}{|l|}{ Boron } \\
\hline Background & $15 / 15$ & 0.09 & 0.37 & 0.83 \\
\hline Plume (520) & $5 / 5$ & 0.14 & 0.30 & 0.40 \\
\hline Other & $21 / 21$ & 0.10 & 0.26 & 0.82 \\
\hline \multicolumn{5}{|l|}{ Cadmium } \\
\hline Background & $6 / 17$ & $<0.001$ & - & 0.015 \\
\hline Plume (520) & $2 / 6$ & $<0.001$ & $\cdot$ & 0.028 \\
\hline Other & $6 / 23$ & $<0.001$ & - & 0.013 \\
\hline \multicolumn{5}{|l|}{ Calcium } \\
\hline Background & $17 / 17$ & 22 & 41 & 282 \\
\hline Plume (520) & $6 / 6$ & 370 & 423 & 630 \\
\hline Other & $24 / 24$ & 18 & 37 & 259 \\
\hline
\end{tabular}


Table 3.2 Summary of filtered ground water quality data in the upper zone at Belfield, North Dakota (1986-1993) (Continued)

\begin{tabular}{|c|c|c|c|c|}
\hline \multirow[b]{3}{*}{ Parameter } & \multirow{3}{*}{$\begin{array}{l}\text { Frequency of } \\
\text { detection }\end{array}$} & \multicolumn{3}{|c|}{ Observed concentrations } \\
\hline & & Minimum & Median ${ }^{b}$ & Maximum \\
\hline & & & $\mathrm{mg} / \mathrm{L}$ & \\
\hline \multicolumn{5}{|l|}{ Chloride } \\
\hline Background & $14 / 15$ & $<1$ & 6 & 50 \\
\hline Plume (520) & $5 / 5$ & 390 & 688 & 755 \\
\hline Other & $18 / 21$ & 2 & 6 & 78 \\
\hline \multicolumn{5}{|l|}{ Chromium } \\
\hline Background & $10 / 17$ & $<0.01$ & 0.01 & 0.09 \\
\hline Plume (520) & $4 / 6$ & $<0.01$ & 0.03 & 0.15 \\
\hline Other & $15 / 24$ & $<0.01$ & 0.02 & 0.09 \\
\hline \multicolumn{5}{|l|}{ Copper } \\
\hline Background & $6 / 15$ & $<0.01$ & - & 0.03 \\
\hline Plume (520) & $5 / 5$ & 0.01 & 0.02 & 0.05 \\
\hline Other & $13 / 20$ & $<0.01$ & 0.01 & 0.04 \\
\hline \multicolumn{5}{|l|}{ Fluoride } \\
\hline Background & $15 / 15$ & 0.32 & 0.71 & 1.91 \\
\hline Plume (520) & $5 / 5$ & 0.18 & 0.26 & 0.30 \\
\hline Other & $21 / 21$ & 0.26 & 0.64 & 1.81 \\
\hline \multicolumn{5}{|l|}{ Iron } \\
\hline Background & $17 / 17$ & 0.02 & 0.07 & 0.98 \\
\hline Plume (520) & $5 / 6$ & $<0.03$ & 0.08 & 0.18 \\
\hline Other & $23 / 24$ & 0.02 & 0.06 & 2.69 \\
\hline \multicolumn{5}{|l|}{ Lead } \\
\hline Background & $11 / 17$ & $<0.001$ & 0.01 & 0.14 \\
\hline Plume $(520)$ & $2 / 6$ & $<0.001$ & $\cdot$ & 0.20 \\
\hline Other & $13 / 23$ & $<0.001$ & 0.01 & 0.13 \\
\hline \multicolumn{5}{|l|}{ Magnesium } \\
\hline Background & $17 / 17$ & 18 & 33 & 183 \\
\hline Plume (520) & $6 / 6$ & 166 & 195 & 298 \\
\hline Other & $24 / 24$ & 11 & 23 & 149 \\
\hline \multicolumn{5}{|l|}{ Manganese } \\
\hline Background & $17 / 17$ & 0.05 & 0.22 & 0.96 \\
\hline Plume (520) & $6 / 6$ & 0.05 & 0.07 & 0.11 \\
\hline Other & $24 / 24$ & 0.05 & 0.17 & 0.57 \\
\hline
\end{tabular}


Table 3.2 Summary of filtered ground water quality data in the upper zone at Belfield, North Dakota (1986-1993) (Continued)

\begin{tabular}{|c|c|c|c|c|}
\hline \multirow[b]{3}{*}{ Parameter } & \multirow{3}{*}{$\begin{array}{l}\text { Frequency of } \\
\text { detection }\end{array}$} & \multicolumn{3}{|c|}{ Observed concentrations } \\
\hline & & Minimum & Median ${ }^{\mathbf{b}}$ & Maximum \\
\hline & & & $\mathrm{mg} / \mathrm{L}$ & \\
\hline \multicolumn{5}{|l|}{ Mercury } \\
\hline Background & $6 / 15$ & $<0.0002$ & $\cdot$ & 0.002 \\
\hline Plume (520) & $2 / 5$ & $<0.0002$ & $\cdot$ & 0.001 \\
\hline Other & $9 / 20$ & $<0.0002$ & $\cdot$ & 0.002 \\
\hline \multicolumn{5}{|l|}{ Molybdenum } \\
\hline Background & $12 / 17$ & $<0.01$ & 0.06 & 0.20 \\
\hline Plume (520) & $5 / 6$ & $<0.01$ & 0.11 & 0.26 \\
\hline Other & $18 / 24$ & $<0.01$ & 0.05 & 0.19 \\
\hline \multicolumn{5}{|l|}{ Nickel } \\
\hline Background & $5 / 11$ & $<0.01$ & $\cdot$ & 0.04 \\
\hline Plume (520) & $2 / 3$ & $<0.01$ & 0.07 & 0.07 \\
\hline Other & $10 / 15$ & $<0.01$ & 0.02 & 0.04 \\
\hline \multicolumn{5}{|l|}{ Nitrate } \\
\hline Background & $6 / 15$ & $<0.1$ & $\cdot$ & 3.2 \\
\hline Plume (520) & $0 / 5$ & $<0.1$ & - & $<1.0$ \\
\hline Other & $18 / 21$ & $<0.1$ & 0.8 & 3.9 \\
\hline \multicolumn{5}{|l|}{ Phosphate } \\
\hline Background & $9 / 11$ & $<0.1$ & 2.1 & 21.5 \\
\hline Plume (520) & $2 / 4$ & $<0.1$ & - & 7.0 \\
\hline Other & $11 / 16$ & $<0.1$ & 1.4 & 36.8 \\
\hline \multicolumn{5}{|l|}{ Potassium } \\
\hline Background & $17 / 17$ & 2.4 & 7.4 & 10.3 \\
\hline Plume (520) & $6 / 6$ & 5.3 & 7.0 & 8.2 \\
\hline Other & $24 / 24$ & 2.9 & 5.6 & 14.2 \\
\hline \multicolumn{5}{|l|}{ Selenium } \\
\hline Background & $11 / 17$ & $<0.001$ & 0.005 & 0.114 \\
\hline Plume (520) & $4 / 6$ & 0.001 & 0.004 & 0.033 \\
\hline Other & $16 / 24$ & $<0.001$ & 0.004 & 0.061 \\
\hline \multicolumn{5}{|l|}{ Silver } \\
\hline Background & $4 / 15$ & $<0.01$ & - & 0.02 \\
\hline Plume (520) & $3 / 5$ & $<0.01$ & 0.02 & 0.03 \\
\hline Other & $7 / 20$ & $<0.01$ & - & 0.02 \\
\hline
\end{tabular}


Table 3.2 Summary of filtered ground water quality data in the upper zone at Belfield, North Dakota (1986-1993) (Continued)

\begin{tabular}{|c|c|c|c|c|}
\hline \multirow[b]{3}{*}{ Parameter } & \multirow{3}{*}{$\begin{array}{l}\text { Frequency of } \\
\text { detection }\end{array}$} & \multicolumn{3}{|c|}{ Observed concentrations } \\
\hline & & Minimum & Median b & Maximum \\
\hline & & & $\mathrm{mg} / \mathrm{L}$ & \\
\hline \multicolumn{5}{|l|}{ Sodium } \\
\hline Background & $17 / 17$ & 228 & 770 & 1910 \\
\hline Plume (520) & $6 / 6$ & 102 & 365 & 454 \\
\hline Other & $24 / 24$ & 188 & 348 & 1080 \\
\hline \multicolumn{5}{|l|}{ Strontium } \\
\hline Background & $15 / 15$ & 0.6 & 1.1 & 2.1 \\
\hline Plume (520) & $5 / 5$ & 2.5 & 3.0 & 3.5 \\
\hline Other & $21 / 21$ & 0.4 & 0.8 & 1.3 \\
\hline \multicolumn{5}{|l|}{ Sulfate } \\
\hline Background & $15 / 15$ & 990 & 1250 & 3110 \\
\hline Plume (520) & $5 / 5$ & 973 & 1090 & 1190 \\
\hline Other & $21 / 21$ & 242 & 330 & 1330 \\
\hline \multicolumn{5}{|l|}{ Sulfide } \\
\hline Background & $2 / 15$ & $<0.1$ & $\cdot$ & 0.5 \\
\hline Plume (520) & $0 / 5$ & $<0.1$ & $\cdot$ & $<0.1$ \\
\hline Other & $0 / 21$ & $<0.1$ & $\cdot$ & $<0.1$ \\
\hline \multicolumn{5}{|l|}{ Uranium } \\
\hline Background & $16 / 17$ & $<0.001$ & 0.019 & 0.057 \\
\hline Plume (520) & $6 / 6$ & 0.073 & 0.085 & 0.106 \\
\hline Other & $22 / 24$ & $<0.001$ & 0.005 & 0.049 \\
\hline \multicolumn{5}{|l|}{ Vanadium } \\
\hline Background & $6 / 17$ & $<0.01$ & - & 0.05 \\
\hline Plume (520) & $4 / 6$ & $<0.01$ & 0.06 & 0.10 \\
\hline Other & $9 / 23$ & $<0.01$ & $\cdot$ & 0.10 \\
\hline \multicolumn{5}{|l|}{ Zinc } \\
\hline Background & $11 / 15$ & $<0.005$ & 0.011 & 0.112 \\
\hline Plume (520) & $3 / 5$ & $<0.005$ & 0.008 & 0.010 \\
\hline Other & $16 / 20$ & $<0.005$ & 0.012 & 0.132 \\
\hline
\end{tabular}


Table 3.2 Summary of filtered ground water quality data in the upper zone at Belfield, North Dakota (1986-1993) (Concluded)

\begin{tabular}{|c|c|c|c|c|}
\hline \multirow[b]{3}{*}{ Parameter } & \multirow{3}{*}{$\begin{array}{c}\text { Frequency of } \\
\text { detection }\end{array}$} & \multicolumn{3}{|c|}{ Observed concentrations } \\
\hline & & Minimum & Median ${ }^{b}$ & Maximum \\
\hline & & \multicolumn{2}{|r|}{$\mathrm{pCi} / \mathrm{L}$} & \\
\hline \multicolumn{5}{|c|}{ Radiochemical parameters } \\
\hline \multicolumn{5}{|l|}{ Lead-210 } \\
\hline Background & NA & 0.0 & 0.1 & 1.3 \\
\hline Plume (520) & NA & 0.2 & 0.8 & 2.8 \\
\hline Other & NA & 0.0 & 0.2 & 1.3 \\
\hline \multicolumn{5}{|l|}{ Polonium-230 } \\
\hline Background & NA & 0.0 & 0.0 & 1.6 \\
\hline Plume (520) & NA & 0.0 & 0.1 & 1.4 \\
\hline Other & NA & 0.0 & 0.0 & 1.5 \\
\hline \multicolumn{5}{|l|}{ Radium-226 } \\
\hline Background & NA & 0.0 & 0.1 & 0.7 \\
\hline Plume (520) & NA & 0.0 & 0.2 & 0.5 \\
\hline Other & NA & 0.0 & 0.1 & 0.6 \\
\hline \multicolumn{5}{|l|}{ Thorium-230 } \\
\hline Background & NA & 0.0 & 0.0 & 0.3 \\
\hline Plume (520) & NA & 0.0 & 0.0 & 0.4 \\
\hline Other & NA & 0.0 & 0.2 & 0.6 \\
\hline
\end{tabular}

${ }^{\text {a }}$ Frequency of detection $=$ number of samples with detectable concentration/total number of samples.

bThe median is the 50th percentile of the sample data. The median cannot be calculated if 50 percent or less of the data are above detection.

${ }^{C}$ Constituents in italics were identified as above background concentrations.

${ }^{d}$ Background DOE wells are 533, 534, 535, and 539.

EOE well 520 is on the site and is the well closest to the former ashing furnace.

'Other DOE wells on the site or downgradient from the site are $522,532,536,537$, and 538 .

NA - Not applicable. 

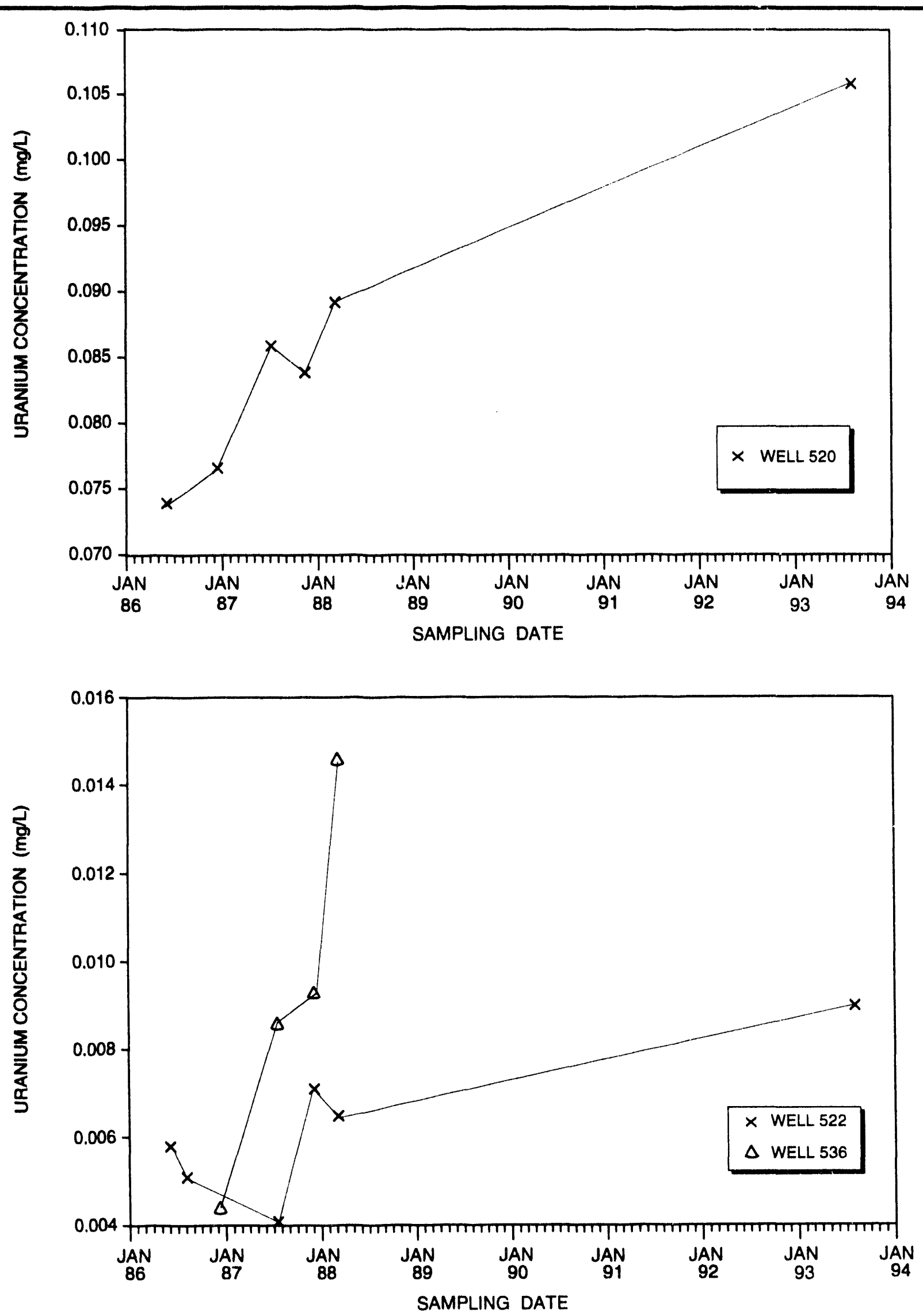

FIGURE 3.2

TRENDS IN URANIUM CONCENTRATIONS IN UPPER ZONE BELFIELD, NORTH DAKOTA, SITE 
comparisun of on-site water quality to background quality is discussed in Section 3.3.

\subsubsection{Site-related contamination in the lignite zone}

Three wells at the site are screened in the lignite zone (DOE monitor wells 521 and 540 and domestic well 526). Water quality data for these wells indicate that the ground water in well $\mathbf{5 2 1}$ has the highest concentrations of metals potentially associated with the ashing process. In addition, well 521 is the closest of the three wells to the location where the highest concentrations of site-related contaminants were recorded in the upper zone (near well 520). Well 521 was therefore used to characterize the level of ground water contamination in the lignite zone relative to background water quality as represented by DOE monitor well 541.

The limited number of DOE monitor wells screened in the lignite zone precluded a rigorous statistical comparison of backgrcund and on-site water quality in the lignite zone. A scan of the data in Table 3.3, however, suggests that concentrations of uranium, chloride, fluoride, magnesium, sodium, strontium, and sulfate are elevated above background levels in ground water in the vicinity of monitor well 521. Furthermore, for the trace elements antimony, cadmium, chromium, copper, lead, mercury, nickel, selenium, silver, vanadium, and zinc, the maximum concentration reported for monitor well 521 is higher than the corresponding maximum concentration reported for background well 541 . However, more data are needed to assess the statistical significance of these phenomena and to determine wheti 3 r these values represent background variability or impacts of the millin, jrocess.

Concentrations of the key constituents uranium and vanadium in monitor well 540, situated downgradient from monitor well 521, are comparable to background levels (well 541). Other water quality parameters are also lower in the region of well 540. This suggests that if contamination is present in the lignite zone in the region of monitor well 521, it is probably rapidiy attenuated by sorption onto the aquifer matrix down the flow path. This concept is supported by data provided in a special study discussing the sorptive properties of lignite. Ground water data from lysimeters and monitor wells in the vicinity of the Bowman, North Dakota, UMTRA Project site indicated that a mechanism in the subsurface removes contaminants from the infiltrating solution by the iron-bearing minerals in the organic-rich lignite beds (DOE, 1991).

A comparison of data from lignite monitor well 521 to the most contaminated upper zone monitor well $\mathbf{5 2 0}$ indicates that constituent levels generally decrease with depth. Two exceptions are sulfate and strontium, which appear consistently higher in lignite well 521. A few cases exist where the maximum concentration in well 521 exceeds the maximum concentration in well 520 (mercury, nitrate, and vanadium), but the remaining data are comparable to or below detection in the lignite well. Although the maximum vanadium concentration in the lignite zone is higher than the maximum concentration in 
Table 3.3 Summary of filtered ground water quality data in the lignite zone at Belfield, North Dakota (1986-1993)

\begin{tabular}{|c|c|c|c|c|}
\hline \multirow[b]{3}{*}{ Parameter } & \multirow{3}{*}{$\begin{array}{c}\text { Frequency of } \\
\text { detection }^{\mathrm{a}}\end{array}$} & \multicolumn{3}{|c|}{ Observed concentrations } \\
\hline & & Minimum & Median $^{\mathbf{b}}$ & Maximum \\
\hline & & & $\mathrm{mg} / \mathrm{L}$ & \\
\hline \multicolumn{5}{|l|}{ Inorganics } \\
\hline \multicolumn{5}{|l|}{ Aluminum } \\
\hline Background ${ }^{C}$ & $3 / 4$ & $<0.10$ & 0.13 & 0.29 \\
\hline $521^{d}$ & $5 / 5$ & 0.10 & 0.14 & 0.26 \\
\hline $540^{d}$ & $3 / 4$ & $<0.10$ & 0.10 & 0.18 \\
\hline \multicolumn{5}{|l|}{ Ammonium } \\
\hline Background & $2 / 4$ & $<0.1$ & $<0.1$ & 0.3 \\
\hline 521 & $4 / 4$ & 0.2 & 0.7 & 0.8 \\
\hline 540 & $4 / 4$ & 0.1 & 0.4 & 0.7 \\
\hline \multicolumn{5}{|l|}{ Antimony } \\
\hline Background & $2 / 4$ & $<0.003$ & $<0.004$ & 0.015 \\
\hline 521 & $3 / 4$ & $<0.003$ & 0.014 & 0.032 \\
\hline 540 & $2 / 4$ & $<0.003$ & 0.010 & 0.030 \\
\hline \multicolumn{5}{|l|}{ Arsenic } \\
\hline Background & $4 / 5$ & 0.001 & $<0.005$ & 0.008 \\
\hline 521 & $1 / 6$ & $<0.001$ & & 0.005 \\
\hline 540 & $2 / 5$ & $<0.001$ & - & 0.006 \\
\hline \multicolumn{5}{|l|}{ Barium } \\
\hline Background & $3 / 4$ & 0.03 & 0.03 & $<0.10$ \\
\hline 521 & $4 / 4$ & 0.02 & 0.03 & 0.20 \\
\hline 540 & $3 / 4$ & 0.02 & 0.02 & $<0.10$ \\
\hline \multicolumn{5}{|l|}{ Boron } \\
\hline Background & $4 / 4$ & 0.20 & 0.29 & 0.48 \\
\hline 521 & $5 / 5$ & 0.10 & 0.49 & 0.60 \\
\hline 540 & $4 / 4$ & 0.43 & 0.60 & 0.70 \\
\hline
\end{tabular}


Table 3.3 Summary of filtered ground water quality data in the lignite zone at Belfield, North Dakota (1986-1993) (Continued)

\begin{tabular}{|c|c|c|c|c|}
\hline \multirow[b]{3}{*}{ Parameter } & \multirow{3}{*}{$\begin{array}{l}\text { Frequency of } \\
\text { detection }\end{array}$} & \multicolumn{3}{|c|}{ Observed concentrations } \\
\hline & & Minimum & Median ${ }^{b}$ & Maximum \\
\hline & & & $\mathrm{mg} / \mathrm{L}$ & \\
\hline \multicolumn{5}{|l|}{ Cadmium } \\
\hline Background & $0 / 5$ & $<0.001$ & - & $<0.005$ \\
\hline 521 & $2 / 5$ & $<0.001$ & - & 0.016 \\
\hline 540 & $0 / 5$ & $<0.001$ & - & $<0.005$ \\
\hline \multicolumn{5}{|l|}{ Calcium } \\
\hline Background & $5 / 5$ & 102 & 173 & 181 \\
\hline 521 & $6 / 6$ & 142 & 163 & 168 \\
\hline 540 & $5 / 5$ & 78 & 96 & 105 \\
\hline \multicolumn{5}{|l|}{ Chloride } \\
\hline Background & $6 / 6$ & 7 & 10 & 12 \\
\hline 521 & $5 / 5$ & 43 & 46 & 53 \\
\hline 540 & $4 / 4$ & 31 & 35 & 40 \\
\hline \multicolumn{5}{|l|}{ Chromium } \\
\hline Background & $2 / 5$ & $<0.01$ & - & 0.06 \\
\hline 521 & $4 / 6$ & $<0.01$ & 0.03 & 0.07 \\
\hline 540 & $2 / 5$ & $<0.01$ & - & 0.04 \\
\hline \multicolumn{5}{|l|}{ Copper } \\
\hline Background & $1 / 4$ & $<0.01$ & - & 0.01 \\
\hline 521 & $3 / 4$ & $<0.01$ & 0.01 & 0.04 \\
\hline 540 & $0 / 4$ & $<0.01$ & - & $<0.01$ \\
\hline \multicolumn{5}{|l|}{ Fluoride } \\
\hline Background & $4 / 4$ & 0.32 & 0.35 & 0.37 \\
\hline 521 & $5 / 5$ & 0.43 & 0.44 & 0.60 \\
\hline 540 & $4 / 4$ & 0.57 & 0.57 & 0.58 \\
\hline \multicolumn{5}{|l|}{ Iron } \\
\hline Background & $5 / 5$ & 0.22 & 0.35 & 0.41 \\
\hline 521 & $6 / 6$ & 0.10 & 0.20 & 0.22 \\
\hline 540 & $5 / 5$ & 0.05 & 0.13 & 0.19 \\
\hline
\end{tabular}


Table 3.3 Summary of filtered ground water quality data in the lignite zone at Belfield, North Dakota (1986-1993) (Continued)

\begin{tabular}{|c|c|c|c|c|}
\hline \multirow[b]{3}{*}{ Parameter } & \multirow{3}{*}{$\begin{array}{l}\text { Frequency of } \\
\text { detection }\end{array}$} & \multicolumn{3}{|c|}{ Observed concentrations } \\
\hline & & Minimum & Median ${ }^{b}$ & Maximum \\
\hline & & & $\mathrm{mg} / \mathrm{L}$ & \\
\hline \multicolumn{5}{|l|}{ Lead } \\
\hline Background & $1 / 5$ & $<0.001$ & - & 0.02 \\
\hline 521 & $3 / 5$ & $<0.003$ & 0.010 & 0.10 \\
\hline 540 & $2 / 5$ & $<0.001$ & - & 0.02 \\
\hline \multicolumn{5}{|l|}{ Magnesium } \\
\hline Background & $5 / 5$ & 58 & 87 & 92 \\
\hline 521 & $6 / 6$ & 96 & 104 & 118 \\
\hline 540 & $5 / 5$ & 60 & 68 & 72 \\
\hline \multicolumn{5}{|l|}{ Manganese } \\
\hline Background & $5 / 5$ & 0.22 & 0.37 & 0.42 \\
\hline 521 & $6 / 6$ & 0.25 & 0.31 & 0.33 \\
\hline 540 & $5 / 5$ & 0.20 & 0.26 & 0.27 \\
\hline \multicolumn{5}{|l|}{ Mercury } \\
\hline Background & $1 / 4$ & $<0.0002$ & & 0.0003 \\
\hline 521 & $1 / 4$ & $<0.0002$ & - & 0.004 \\
\hline 540 & $1 / 4$ & $<0.0002$ & - & 0.0002 \\
\hline \multicolumn{5}{|l|}{ Molybdenum } \\
\hline Background & $4 / 5$ & $<0.01$ & 0.10 & 0.12 \\
\hline 521 & $5 / 6$ & $<0.01$ & 0.08 & 0.13 \\
\hline 540 & $4 / 5$ & $<0.01$ & 0.08 & 0.20 \\
\hline \multicolumn{5}{|l|}{ Nickel } \\
\hline Background & $1 / 3$ & $<0.01$ & - & 0.03 \\
\hline 521 & $2 / 3$ & $<0.01$ & 0.03 & 0.04 \\
\hline 540 & $1 / 3$ & $<0.01$ & - & 0.02 \\
\hline \multicolumn{5}{|l|}{ Nitrate } \\
\hline Background & $1 / 4$ & $<0.1$ & $\cdot$ & 0.1 \\
\hline 521 & $1 / 5$ & $<0.1$ & - & 6.0 \\
\hline 540 & $3 / 4$ & $<0.1$ & 0.6 & 1.3 \\
\hline
\end{tabular}


Table 3.3 Summary of filtered ground water quality data in the lignite zone at Belfield, North Dakota (1986-1993) (Continued)

\begin{tabular}{|c|c|c|c|c|}
\hline \multirow[b]{3}{*}{ Parameter } & \multirow{3}{*}{$\begin{array}{c}\text { Frequency of } \\
\text { detection }\end{array}$} & \multicolumn{3}{|c|}{ Observed concentrations } \\
\hline & & Minimum & Median ${ }^{\mathbf{b}}$ & Maximum \\
\hline & & & $\mathrm{mg} / \mathrm{L}$ & \\
\hline \multicolumn{5}{|l|}{ Phosphate } \\
\hline Background & $1 / 3$ & $<0.1$ & - & 36 \\
\hline 521 & $2 / 4$ & $<0.1$ & 0.3 & 2.9 \\
\hline 540 & $2 / 3$ & $<0.1$ & 0.5 & 30.1 \\
\hline \multicolumn{5}{|l|}{ Potassium } \\
\hline Background & $5 / 5$ & 5.2 & 5.4 & 15.6 \\
\hline 521 & $6 / 6$ & 7.0 & 7.2 & 8.8 \\
\hline 540 & $5 / 5$ & 6.7 & 7.0 & 8.6 \\
\hline \multicolumn{5}{|l|}{ Selenium } \\
\hline Background & $3 / 5$ & $<0.001$ & 0.005 & 0.018 \\
\hline 521 & $3 / 6$ & 0.001 & $<0.005$ & 0.046 \\
\hline 540 & $3 / 5$ & $<0.001$ & $<0.005$ & 0.039 \\
\hline \multicolumn{5}{|l|}{ Silver } \\
\hline Background & $3 / 4$ & $<0.01$ & 0.01 & 0.01 \\
\hline 521 & $3 / 4$ & $<0.01$ & 0.02 & 0.02 \\
\hline 540 & $2 / 4$ & $<0.01$ & $<0.01$ & 0.01 \\
\hline \multicolumn{5}{|l|}{ Sodium } \\
\hline Background & $5 / 5$ & 230 & 344 & 395 \\
\hline 521 & $6 / 6$ & 598 & 667 & 747 \\
\hline 540 & $5 / 5$ & 639 & 672 & 736 \\
\hline \multicolumn{5}{|l|}{ Strontium } \\
\hline Background & $4 / 4$ & 2.2 & 2.6 & 2.9 \\
\hline 521 & $5 / 5$ & 3.6 & 4.6 & 5.6 \\
\hline 540 & $4 / 4$ & 2.1 & 2.4 & 2.5 \\
\hline \multicolumn{5}{|l|}{ Sulfate } \\
\hline Background & $4 / 4$ & 803 & 988 & 1030 \\
\hline 521 & $5 / 5$ & 1490 & 1610 & 1790 \\
\hline 540 & $4 / 4$ & 1300 & 1335 & 1390 \\
\hline
\end{tabular}


Table 3.3 Summary of filtered ground water quality data in the lignite zone at Belfield, North Dakota (1986-1993) (Continued)

\begin{tabular}{|c|c|c|c|c|}
\hline \multirow[b]{3}{*}{ Parameter } & \multirow{3}{*}{$\begin{array}{c}\text { Frequency of } \\
\text { detection } \mathrm{a}\end{array}$} & \multicolumn{3}{|c|}{ Observed concentrations } \\
\hline & & Minimum & Median $^{\mathbf{b}}$ & Maximum \\
\hline & & & $\mathrm{mg} / \mathrm{L}$ & \\
\hline \multicolumn{5}{|l|}{ Sulfide } \\
\hline Background & $1 / 4$ & $<0.1$ & - & 0.1 \\
\hline 521 & $1 / 5$ & $<0.1$ & - & 0.1 \\
\hline 540 & $1 / 4$ & $<0.1$ & - & 0.1 \\
\hline \multicolumn{5}{|l|}{ Uranium } \\
\hline Background & $1 / 5$ & $<0.0003$ & - & 0.0003 \\
\hline 521 & $4 / 6$ & $<0.0003$ & $<0.001$ & 0.0036 \\
\hline 540 & $1 / 5$ & $<0.0003$ & - & 0.0003 \\
\hline \multicolumn{5}{|l|}{ Vanadium } \\
\hline Background & $3 / 5$ & $<0.01$ & 0.03 & 0.04 \\
\hline 521 & $4 / 5$ & $<0.01$ & 0.03 & 0.21 \\
\hline 540 & $3 / 5$ & $<0.01$ & 0.02 & 0.04 \\
\hline \multicolumn{5}{|l|}{ Zinc } \\
\hline Background & $2 / 4$ & $<0.005$ & 0.013 & 0.053 \\
\hline 521 & $4 / 4$ & 0.008 & 0.023 & 0.113 \\
\hline 540 & $2 / 4$ & $<0.005$ & $<0.010$ & 0.020 \\
\hline
\end{tabular}


Table 3.3 Summary of filtered ground water quality data in the lignite zone at Belfield, North Dakota (1986-1993) (Concluded)

\begin{tabular}{|c|c|c|c|c|}
\hline \multirow[b]{3}{*}{ Parameter } & \multirow{3}{*}{$\begin{array}{c}\text { Frequency of } \\
\text { detection }\end{array}$} & \multicolumn{3}{|c|}{ Observed concentrations } \\
\hline & & Minimum & Median ${ }^{b}$ & Maximum \\
\hline & & & $\mathrm{pCi} / \mathrm{L}$ & \\
\hline \multicolumn{5}{|l|}{ Radionuclides } \\
\hline \multicolumn{5}{|l|}{ Lead-210 } \\
\hline Background & NA & 0.0 & $\cdot$ & 0.0 \\
\hline 521 & NA & 0.0 & - & 0.0 \\
\hline 540 & NA & 0.0 & - & 0.0 \\
\hline \multicolumn{5}{|l|}{ Polonium-210 } \\
\hline Background & NA & 0.0 & - & 0.0 \\
\hline 521 & NA & 0.0 & - & 0.0 \\
\hline 540 & NA & 0.0 & - & 0.4 \\
\hline \multicolumn{5}{|l|}{ Radium-226 } \\
\hline Background & NA & 0.1 & 0.3 & 0.4 \\
\hline 521 & NA & 0.0 & 0.0 & 0.3 \\
\hline 540 & NA & 0.1 & 0.2 & 0.4 \\
\hline \multicolumn{5}{|l|}{ Thorium-230 } \\
\hline Background & NA & 0.0 & - & 0.0 \\
\hline 521 & NA & 0.1 & - & 0.2 \\
\hline 540 & NA & 0.0 & - & 0.6 \\
\hline
\end{tabular}

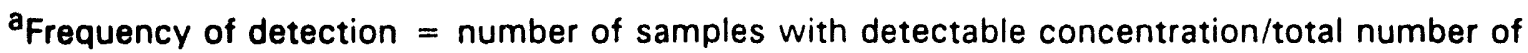
samples.

${ }^{b}$ Median is the 50 th percentile of the sample data. The median cannot be calculated if 50 percent or less of the data are above detection.

'DOE well 541 represented background.

${ }^{d}$ DOE wells 521 and 540 are on the site.

NA - Not applicable. 
the upper zone, the probability distribution simulated for exposure to vanadium through ground water ingestion includes values as high as the one seen in well 521. The higher strontium and sulfate concentrations in the lignite zone would not vary the results of the screening for contaminants of potential concern, because levels are still within the range of no observed adverse effects. Therefore, exposure to contaminant levels in the upper zone represent the greatest potential risk and were evaluated in this risk assessment.

\subsection{CONTAMINANTS OF POTENTIAL CONCERN}

The data discussed in Sections 3.1 and 3.2 were used to compile a list of contaminants of potential concern for the assessment of human health risks from ground water ingestion at the Belfield UMTRA Project site. Levels of constituents potentially attributable to the ashing process are higher in the upper zone (sandy clay layer) than in the lignite zone. Therefore, contamination in the upper zone is evaluated quantitatively to determine the greatest risk from ground water. Based on the previous assessment of water quality and contamination attributable to the ashing process, any potential risks from exposure to ground water in the lignite zone would be less than for the upper zone and therefore are not evaluated further.

Water quality data for the upper zone were reviewed and analyzed to determine the list of contaminants of potential concern for human health. If concentrations of a constituent in on-site monitor well 520 were, on average, higher than those in the background wells $(533,534,535$, and 539), it was put on the initial list of contaminarits of potential concern (Table 3.4, column 1). The statistical comparison was made at the 0.05 level of significance with a nonparametric Mann-Whitney test.

Table 3.4 Contaminants of potential concern for human health evaluation

\begin{tabular}{|c|c|c|c|}
\hline $\begin{array}{l}\text { Constituents that } \\
\text { exceed background }\end{array}$ & $\begin{array}{c}\text { Constituents in the } \\
\text { nutritional range }\end{array}$ & $\begin{array}{c}\text { Constituents with low } \\
\text { toxicity and/or high } \\
\text { dietary range }\end{array}$ & $\begin{array}{l}\text { Contaminants of } \\
\text { potential concern } \\
\text { for human health }\end{array}$ \\
\hline $\begin{array}{l}\text { Aluminum } \\
\text { Barium } \\
\text { Calcium } \\
\text { Chloride } \\
\text { Copper } \\
\text { Magnesium } \\
\text { Silver } \\
\text { Strontium } \\
\text { Uranium } \\
\text { Vanadium }\end{array}$ & $\begin{array}{l}\text { Calcium } \\
\text { Copper } \\
\text { Magnesium }\end{array}$ & $\begin{array}{l}\text { Aluminum } \\
\text { Barium } \\
\text { Chloride } \\
\text { Silver } \\
\text { Strontium }\end{array}$ & $\begin{array}{l}\text { Uranium } \\
\text { Vanadium }\end{array}$ \\
\hline
\end{tabular}

Note: Contaminants of potential concern (column 4) are determined hy eliminating the constituents in columns 2 and 3 from those in column 1. 
Based on this initial screening criterion, constituents detected on the site but not elevated above background levels did not become site-related contaminants of potential concern. Several water quality parameters, although not elevated above background levels on-site, were detected in background ground water at levels above health-based criteria and/or the EPA maximum concentration limit (MCL). In the case of Belfield, adverse health effects would be expected from the chronic ingestion of ground water as defined by background water quality. Any risks identified for the site-related contaminants of potential concern would be incremental. The potential impacts from ingesting background ground water in the site vicinity were not evaluated individually in the toxicity assessment and risk evaluation. However, a comparison of background water quality to the available health-based criteria and/or EPA MCLs is presented in Section 8.0 and applied to the overall interpretation of site conditions.

This initial list of site-related constituents was further evaluated for toxicity to human health using health-based criteria. Several constituents, although present above background levels, were screened from the list because their concentrations are within an acceptable nutritional range, are at a low toxicity level, or are within the expected dietary range. The criteria for acceptable nutritional range is based on the Federal Drug Administration's (FDA) recommended dietary allowance (RDA), while the criteria for expected dietary range are based on information published in the Agency for Toxic Substances and Disease Registry (ATSDR), the EPA's Integrated Risk Information System (IRIS), and the Handbook on the Toxicology of Metals (Friberg et al., 1986). These publications identify common intake rates for specific nutrients. A constituent was considered to have low toxicity when the anticipated exposure dose fell well below any known adverse health effect level as stated in the literature.

Uranium and vanadium remained as the contaminants of potential concern for human health associated with the upper zone at the Belfield site (column 4 . Table 3.4).

Radionuclides associated with natural uranium were not statistically elevated above background levels and therefore were not included on the list of contaminants of potential concern. However, data for these radionuclides are incorporated into the assessment of lifetime cancer risk (Section 6.2). Effects from radioactivity are considered additive; therefore, even naturally occurring concentrations contribute to the total cancer risk. Furthermore, since uranium is attributed to the ashing process, its radioactive progeny may be considered a site-related health risk.

Data for organic analyses are unavailable, and the potential for risks from the presence of organics was not investigated.

A qualitative review of water quality in the lignite zone (Section 3.2.2) revealed several constituents potentially above background levels defined for the lignite. Levels of these constituents were lower than those in the upper zone, except 
for strontium, which was slightly higher in the lignite zone. The presence of strontium in the lignite zone is not clearly attributable to the processing site. Therefore, concentrations of strontium in the upper zone were used in the screening exercise applied to select contaminants of potential concern for human health. Results of the screening would have been the same using either level of strontium.

The health effects of specific constituents differ for biota. The initial list of contaminants of potential concern, derived from those constituents statistically above background levels and therefore attributable to the processing site, was evaluated for ecological risks in Section 7.0. The screening of constituents follows health criteria unique to biota.

Soil contamination attributable to the ashing process is present surrounding the Belfield site (Figure 3.1) (DOE, 1990). However, impacts to ground water have not been observed beyond the site boundary. Ground water data for wells downgradient from monitor well 520 suggest that contamination is not migrating away from the region of well 520, where the highest levels of contaminants were identified. Based on this information, site-related contamination is not thought to be migrating off the site. Further investigations into the potential time trend in uranium concentrations would help in this interpretation.

To predict the fate and transport of the contaminants of potential concern in the aquifer, a hydrogeochemical analysis was performed based on contaminated water quality in monitor well 520. The analysis relied on geochemical modeling and observation of the spatial and temporal distribution of elements in ground water. Geochemical modeling using the computer codes MINTEQA2/PRODEFA2 (Allison et al., 1991) was used to determine 1) the species in which contaminants of potential concern are present in ground water beneath the site and 2) the saturation indices to determine which mineral phases are saturated with respect to solute in ground water and, therefore, could potentially remove constituents from the plume through precipitation. Aqueous species of contaminants of potential concern, calculated through geochemical modeling, are presented in Table 3.5.

Concentrations of elements in ground water are influenced by five factors: 1) the chemistry of ground water, including $\mathrm{pH}$ and reduction-oxidation potential; 2) the structure of the aquifer; 3) the mineralogy and chemical composition of the aquifer matrix (in this case, lignite probably controls sorption processes); 4) hydrodynamic dispersion (resulting in dilution and mixing); and 5) precipitation of solid phases. Of all the processes mentioned above, the sorption properties of lignite appear to control the mobility of constituents in ground water beneath the Belfield site. 
Table 3.5 Aqueous species of constituents of potential concern in ground water beneath the Belfield, North Dakota, site

\begin{tabular}{|c|c|c|c|}
\hline Constituents & Chemical name & Species $^{a}$ & Molar percent \\
\hline \multirow[t]{4}{*}{ Uranium } & Hexavalent uranium & & \\
\hline & Uranyl tricarbonate & $\mathrm{UO}_{2}\left(\mathrm{CO}_{3}\right)_{3}^{4 \cdot}$ & 63 \\
\hline & Uranyl dicarbonate & $\mathrm{UO}_{2}\left(\mathrm{CO}_{3}\right)_{2}{ }^{2-}$ & 35 \\
\hline & Uranyl carbonate & $\mathrm{UO}_{2}\left(\mathrm{CO}_{3}\right)_{A O}$ & 2 \\
\hline \multirow[t]{9}{*}{ Vanadium } & Pentavalent vanadium & & \\
\hline & Orthovanadate & $\mathrm{H}_{2} \mathrm{VO}_{4}^{-}$ & 53 \\
\hline & Pyrovanadate & $\mathrm{HV}_{2} \mathrm{O}_{7}{ }^{3-}$ & 44 \\
\hline & Orthovanadate & $\mathrm{HVO}_{4}{ }^{2-}$ & 3 \\
\hline & Tetravalent vanadium & & \\
\hline & Vanadite trihydroxide & $\mathrm{V}(\mathrm{OH})_{3}{ }^{1+}$ & 75 \\
\hline & Vanadite dioxide & $\mathrm{Vo}^{2+}$ & 15 \\
\hline & Quadrioxide vanadite & $\mathrm{H}_{2} \mathrm{~V}_{2} \mathrm{O}_{4}{ }^{2+}$ & 7 \\
\hline & Vanadite sulfate & $\mathrm{VOSO}_{4 A O}$ & 3 \\
\hline
\end{tabular}

${ }^{a}$ Geochemical modeling with MINTEQA2/PRODEFA2 (Allison et al., 1991) using ground water quality from monitor well 520 was used to calculate species.

Note: Reduction-oxidation information was taken from Garrels and Christ, 1965.

\section{Uranium}

Elevated concentrations of uranium are present in ground water tapped by monitor well 520, most likely as a result of the ashing process. Under moderately oxidizing conditions, uranium is present as a uranyl carbonate complex (Table 3.5). No mineral phases are thermodynamically saturated with respect to uranium in ground water in the contaminated region of the aquifer, so the removal of uranium by precipitation is not expected. However, sorption of uranium onto the aquifer matrix can be expected, especially in the presence of iron oxyhydroxides (Rai and Zachara, 1984), humic material (Karner et al., 1986), and lignite (Miller and Given, 1986). Concentrations of uranium in most wells on and adjacent to the site, other than in well 520, are only slightly above measured background levels. Therefore, minimal attenuation would lower concentrations to those of background levels. The potential increasing trend over time in uranium identified in monitor wells 520,522, and 536 could be the result of water quality variability expected as a result of these natural processes. 


\section{Yanadium}

Vanadium contamination in well 520 is likely due to the ashing process.

Vanadium is present as V(IV) and V(V) oxyanion complexes (Table 3.5).

Vanadium oxide $\left(\mathrm{V}_{2} \mathrm{O}_{4}\right)$ is oversaturated with respect to vanadium in ground water and could potentially attenuate vanadium from the contaminated zone. but little is known about the kinetics of this reaction. However, sorption onto aquifer materials (e.g., chemically active lignite stringers [Karner et al., 1986] and iron oxyhydroxides [Rai and Zachara, 1984]) probably is responsible for attenuation of vanadium down the ground water flow path. Like uranium, vanadium concentrations in most wells on and adjacent to the site, other than well 520, are very close to background concentrations.

\subsection{SURFACE WATER QUALITY DATA SUMMARY}

No surface expression of shallow ground water occurs in the site vicinity. The only surface water in the vicinity of the Belfield site is the North Branch of the Heart River. Flow in the river is sporadic, usually in response to runoff and precipitation events. Sampling locations frequently consisted of turbid disconnected puddles along the dry river bed. Under these conditions, water quality likely reflects constituent levels that have concentrated due to evaporation.

The intermittent and seasonal nature of surface water flow makes it difficult to determine surface water quality. It varies throughout the year, depending on the amount of water available from the hydrologic system. Chemical constituents and concentrations in the surface water at any specific sampling point would depend on the temporal and spatial distribution of the water source, paths of surface water migration, and availability of possible contaminants. Since ground water does not reach surface water in the site vicinity, any contamination found in surface water would likely be attributable to surface runoff of soil contamination.

Five surface water sampling rounds for filtered samples were conducted along the Heart River between 1986 and 1988 (Table 3.6). In addition, one round of unfiltered water samples was collected and analyzed for selected constituents in 1993. Surface sampling locations along the river were not identical from one sampling round to the next, but efforts were made to include at least one location upstream and some adjacent to the site during each surface water sampling event (TAC, 1993) (Figure 2.7). The sampling logs record the river as "flowing" on only one occasion. Table 3.6 summarizes filtered surface water quality in the North Branch of the Heart River.

Water quality was evaluated for the presence of site-related contaminants of potential concern. Statistical analysis of the data was not possible because of the small sample size available. In general, upstream water sampling locations 529 and 546 showed concentrations of metals equal to or higher than sampling locations adjacent to the contaminated area on the site (locations 547 and 530 ). For calcium and strontium, the maximum (but not the median) concentrations were higher adjacent to the site. Products of the uranium decay chain were detected inconsistently and at low levels in surface water samples taken near 
Table 3.6 Summary of filtered surface water quality at Belfield, North Dakota (1986-1988)

\begin{tabular}{|c|c|c|c|c|}
\hline \multirow[b]{3}{*}{ Parameter } & \multirow{3}{*}{$\begin{array}{l}\text { Frequency of } \\
\text { detection }\end{array}$} & \multicolumn{3}{|c|}{ Observed concentrations } \\
\hline & & Minimum & Median $^{\mathbf{b}}$ & Maximum \\
\hline & & & $\mathrm{mg} / \mathrm{L}$ & \\
\hline \multicolumn{5}{|c|}{ Inorganic parameters } \\
\hline \multicolumn{5}{|l|}{ Aluminum } \\
\hline Upgradient $^{\mathrm{C}}$ & $4 / 5$ & $<0.10$ & 0.15 & 0.50 \\
\hline Adjacent ${ }^{d}$ & $4 / 5$ & 0.09 & 0.12 & 0.40 \\
\hline \multicolumn{5}{|l|}{ Ammonium } \\
\hline Upgradient & $2 / 4$ & $<0.1$ & $\cdot$ & 0.7 \\
\hline Adjacent & $2 / 4$ & $<0.1$ & - & 0.6 \\
\hline \multicolumn{5}{|l|}{ Antimony } \\
\hline Upgradient & $3 / 3$ & 0.004 & 0.026 & 0.040 \\
\hline Adjacent & $3 / 3$ & 0.005 & 0.020 & 0.033 \\
\hline \multicolumn{5}{|l|}{ Arsenic } \\
\hline Upgradient & $3 / 5$ & $<0.001$ & 0.003 & 0.020 \\
\hline Adjacent & $2 / 5$ & $<0.001$ & $\cdot$ & 0.015 \\
\hline \multicolumn{5}{|l|}{ Barium } \\
\hline Upgradient & $3 / 4$ & 0.03 & 0.04 & 0.06 \\
\hline Adjacent & $3 / 4$ & 0.03 & 0.04 & 0.04 \\
\hline \multicolumn{5}{|l|}{ Boron } \\
\hline Upgradient & $4 / 4$ & 0.25 & 0.29 & 0.40 \\
\hline Adjacent & $4 / 4$ & 0.25 & 0.32 & 0.38 \\
\hline \multicolumn{5}{|l|}{ Cadmium } \\
\hline Upgradient & $1 / 4$ & $<0.001$ & - & 0.018 \\
\hline Adjacent & $1 / 4$ & $<0.001$ & - & 0.012 \\
\hline \multicolumn{5}{|l|}{ Calcium } \\
\hline Upgradient & $5 / 5$ & 43 & 187 & 480 \\
\hline Adjacent & $5 / 5$ & 45 & 168 & 641 \\
\hline \multicolumn{5}{|l|}{ Chloride } \\
\hline Upgradient & $5 / 5$ & 36 & 482 & 715 \\
\hline Adjacent & $5 / 5$ & 30 & 62 & 86 \\
\hline \multicolumn{5}{|l|}{ Chromium } \\
\hline Upgradient & $3 / 4$ & $<0.01$ & 0.02 & 0.06 \\
\hline Adjacent & $3 / 4$ & $<0.01$ & 0.03 & 0.03 \\
\hline
\end{tabular}


Table 3.6 Summary of filtered surface water quality at Belfield, North Dakota (1986-1988) (Continued)

\begin{tabular}{|c|c|c|c|c|}
\hline \multirow[b]{3}{*}{ Parameter } & \multirow{3}{*}{$\begin{array}{l}\text { Frequency of } \\
\text { detection }\end{array}$} & \multicolumn{3}{|c|}{ Observed concentrations } \\
\hline & & Minimum & Median ${ }^{b}$ & Maximum \\
\hline & & & $\mathrm{mg} / \mathrm{L}$ & \\
\hline \multicolumn{5}{|l|}{ Copper } \\
\hline Upgradient & $2 / 4$ & $<0.01$ & - & 0.01 \\
\hline Adjacent & $1 / 4$ & $<0.01$ & - & 0.01 \\
\hline \multicolumn{5}{|l|}{ Fluoride } \\
\hline Upgradient & $5 / 5$ & 0.11 & 0.28 & 0.40 \\
\hline Adjacent & $5 / 5$ & 0.13 & 0.28 & 0.40 \\
\hline \multicolumn{5}{|l|}{ Iron } \\
\hline Upgradient & $5 / 5$ & 0.06 & 0.21 & 0.38 \\
\hline Adjacent & $5 / 5$ & 0.01 & 0.16 & 0.23 \\
\hline \multicolumn{5}{|l|}{ Lead } \\
\hline Upgradient & $2 / 4$ & $<0.001$ & - & 0.10 \\
\hline Adjacent & $2 / 4$ & $<0.001$ & $\cdot$ & 0.06 \\
\hline \multicolumn{5}{|l|}{ Magnesium } \\
\hline Upgradient & $5 / 5$ & 42 & 179 & 421 \\
\hline Adjacent & $5 / 5$ & 42 & 172 & 425 \\
\hline \multicolumn{5}{|l|}{ Manganese } \\
\hline Upgradient & $5 / 5$ & 0.10 & 0.20 & 1.54 \\
\hline Adjacent & $5 / 5$ & 0.03 & 0.11 & 1.17 \\
\hline \multicolumn{5}{|l|}{ Mercury } \\
\hline Upgradient & $3 / 4$ & $<0.0002$ & 0.0002 & 0.0004 \\
\hline Adjacent & $3 / 4$ & $<0.0002$ & 0.0002 & 0.0004 \\
\hline \multicolumn{5}{|l|}{ Molybdenum } \\
\hline Upgradient & $5 / 5$ & 0.05 & 0.13 & 0.24 \\
\hline Adjacent & $5 / 5$ & 0.04 & 0.11 & 0.20 \\
\hline \multicolumn{5}{|l|}{ Nickel } \\
\hline Upgradient & $2 / 3$ & $<0.01$ & 0.03 & 0.03 \\
\hline Adjacent & $2 / 3$ & $<0.01$ & 0.02 & 0.03 \\
\hline \multicolumn{5}{|l|}{ Nitrate } \\
\hline Upgradient & $4 / 5$ & 0.2 & 1.5 & 6.7 \\
\hline Adjacent & $3 / 5$ & $<0.1$ & 1.0 & 2.0 \\
\hline
\end{tabular}


Table 3.6 Summary of filtered surface water quality at Belfield, North Dakota (1986-1988) (Continued)

\begin{tabular}{|c|c|c|c|c|}
\hline \multirow[b]{3}{*}{ Parameter } & \multirow{3}{*}{$\begin{array}{c}\text { Frequency of } \\
\text { detection } 8\end{array}$} & \multicolumn{3}{|c|}{ Observed concentrations } \\
\hline & & Minimum & Median $^{\mathbf{b}}$ & Maximum \\
\hline & & & $\mathrm{mg} / \mathrm{L}$ & \\
\hline \multicolumn{5}{|l|}{ Phosphate } \\
\hline Upgradient & $3 / 4$ & $<0.1$ & 1.75 & 12.0 \\
\hline Adjacent & $3 / 4$ & $<0.1$ & 1.20 & 12.2 \\
\hline \multicolumn{5}{|l|}{ Potassium } \\
\hline Upgradient & $5 / 5$ & 5.5 & 17 & 18 \\
\hline Adjacent & $5 / 5$ & 7.2 & 16 & 16 \\
\hline \multicolumn{5}{|l|}{ Selenium } \\
\hline Upgradient & $2 / 5$ & $<0.001$ & - & 0.14 \\
\hline Adjacent & $3 / 5$ & $<0.001$ & 0.001 & 0.07 \\
\hline \multicolumn{5}{|l|}{ Silver } \\
\hline Upgradient & $2 / 4$ & $<0.01$ & - & 0.02 \\
\hline Adjacent & $1 / 4$ & $<0.01$ & - & 0.02 \\
\hline \multicolumn{5}{|l|}{ Sodium } \\
\hline Upgradient & $5 / 5$ & 306 & 904 & 1950 \\
\hline Adjacent & $5 / 5$ & 224 & 650 & 1300 \\
\hline \multicolumn{5}{|l|}{ Strontium } \\
\hline Upgradient & $4 / 4$ & 0.35 & 1.1 & 2.8 \\
\hline Adjacent & $4 / 4$ & 0.36 & 1.0 & 5.0 \\
\hline \multicolumn{5}{|l|}{ Sulfate } \\
\hline Upgradient & $5 / 5$ & 776 & 2590 & 5340 \\
\hline Adjacent & $5 / 5$ & 496 & 1990 & 5020 \\
\hline \multicolumn{5}{|l|}{ Sulfide } \\
\hline Upgradient & $1 / 5$ & $<0.1$ & - & 0.1 \\
\hline Adjacent & $0 / 5$ & $<0.1$ & $\cdot$ & $<0.1$ \\
\hline \multicolumn{5}{|l|}{ Uranium } \\
\hline Upgradient & $5 / 5$ & 0.007 & 0.011 & 0.09 \\
\hline Adjacent & $5 / 5$ & 0.009 & 0.011 & 0.07 \\
\hline \multicolumn{5}{|l|}{ Vanadium } \\
\hline Upgradient & $3 / 4$ & $<0.01$ & 0.02 & 0.07 \\
\hline Adjacent & $3 / 4$ & $<0.01$ & 0.01 & 0.07 \\
\hline \multicolumn{5}{|l|}{ Zinc } \\
\hline Upgradient & $4 / 4$ & 0.008 & 0.016 & 0.023 \\
\hline Adjacent & $2 / 4$ & $<0.005$ & 0.005 & 0.021 \\
\hline
\end{tabular}


Table 3.6 Summary of filtered surface water quality at Belfield, North Dakota (1986-1988) (Concluded)

\begin{tabular}{|c|c|c|c|c|}
\hline \multirow[b]{3}{*}{ Parameter } & \multirow{3}{*}{$\begin{array}{c}\text { Frequency of } \\
\text { detection }\end{array}$} & \multicolumn{3}{|c|}{ Observed concentrations } \\
\hline & & Minimum & Median ${ }^{\text {b }}$ & Maximum \\
\hline & & \multicolumn{2}{|r|}{$\mathrm{pCi} / \mathrm{L}$} & \\
\hline \multicolumn{5}{|c|}{ Radiochemical parameters } \\
\hline \multicolumn{5}{|l|}{ Lead-210 } \\
\hline Upgradient & NA & 0.0 & - & 0.0 \\
\hline Adjacent & NA & 0.0 & - & 0.3 \\
\hline \multicolumn{5}{|l|}{ Polonium-230 } \\
\hline Upgradient & NA & 0.0 & - & 0.0 \\
\hline Adjacent & NA & 0.0 & - & 0.0 \\
\hline \multicolumn{5}{|l|}{ Radium-226 } \\
\hline Upgradient & NA & 0.0 & $\cdot$ & 0.2 \\
\hline Adjacent & NA & 0.0 & $\cdot$ & 0.2 \\
\hline \multicolumn{5}{|l|}{ Thorium-230 } \\
\hline Upgradient & NA & 0.0 & - & 0.1 \\
\hline Adjacent & NA & 0.2 & - & 0.4 \\
\hline
\end{tabular}

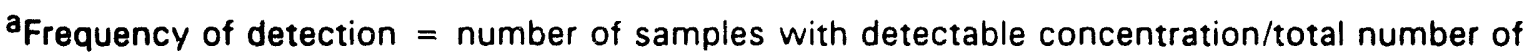
samples.

bThe median is the 50 ih percentile of the sample data. The median cannot be calculated if 50 percent or less of the data are above detection.

CUpstream sampling locations are DOE location 529 (sampling dates: June 1986, December 1986, and July 1987) and DOE location 546 (sampling dates: December 1987 and March 1988).

dSampling locations adjacent to the site are DOE location 530 (sampling dates: June 1986,

December 1986, and July 1987) and DOE location 547 (sampling dates: December 1987 and March 1988). 
the contaminated area of the site. The trace metals cadmium, chromium, molybdenum, uranium, lead, and selenium are present consistently in anomalously high concentrations in filtered samples. These metals appear to be randomly distributed throughout sampling locations. Potential impacts from surrounding soil contamination likely influence these results but are indistinguishable given the limited data set.

Unfiltered water samples collected in 1993 were analyzed for chromium, molybdenum, and selenium. Results for each of these parameters at all sampling locations were below the laboratory detection limit. Total uranium was measured also. Sampling locations 498 and 530, adjacent to the site, showed lower uranium concentrations $(0.027$ and $0.020 \mathrm{mg} / \mathrm{L}$, respectively). Sampling location 529, upstream of the site, had the highest uranium concentration $(0.055 \mathrm{mg} / \mathrm{L})$.

Surface water quality in the vicinity of the Belfield site appears to be a sodium-sulfate type water. The quality fluctuates, depending on the volume of flow and the time of year. Neither the filtered nor the unfiltered data contained evidence that site-related contamination is affecting surface water quality around the site, although the data are limited. Impacts directly from ground water are not expected. The presence of particular constituents is likely attributable to surrounding industrial and agricultural activities. Highway 85 and the Highway Department's sand storage yard are located upstream and within $0.25 \mathrm{mi}(0.4 \mathrm{~km})$ of the site, which could be contributing to the elevated chloride levels observed in the site vicinity.

Elevated concentrations of trace metals in surface water samples may be attributed to 1 ) the regional elevated concentrations of trace elements in sediments of the Sentinel Butte member of the Fort Union Formation, 2) the ephemeral nature of flow of the North Branch of the Heart River, and 3) the concentrating effect of evaporation in standing pools in the river bed. Furthermore, influences from non-point source contamination from runoff or underground seepage from the sewage lagoons have not been characterized.

Sediment samples were collected along with surface water samples during the 1993 sampling round. Sediments were analyzed for selenium, molybdenum, uranium, and chromium. Data indicate no impacts from the ashing process or from ground water contamination. These data are examined further in Section 7.0. 


\subsection{EXPOSURE ASSESSMENT}

\subsection{POTENTIALLY EXPOSED POPULATION}

Exposure can occur only if there is a source of contamination, a mechanism of contaminant transport, and a receptor population or individual. Residents in and around the town of Belfield, North Dakota, are supplied by a municipal water system generating ground water from four wells (more than $1000 \mathrm{ft}[300 \mathrm{~m}]$ deep) penetrating the deep sandstone hydrogeologic units in the region. Ground water from the upper zone is not used as the primary drinking water source in the Belfield site vicinity. However, shallow domestic wells do exist in the area, and there is potential for this ground water to be used for drinking. A water use survey conducted for the area indicates that there are several domestic wells within a $1-\mathrm{mi}(1.6-\mathrm{km})$ radius of the Belfield site, and that most uses of the shallow ground water are washing, cleaning, flushing toilets, gardening, and watering livestock. One residence in the area is currently using shallow ground water for all household purposes, including drinking. Ground water contamination has not been detected off the site and does not appear to be migrating. Therefore, impacts to domestic wells away from the site are not expected, but the potential exists for contaminated ground water to affect the domestic wells located on the site and for these domestic wells to be used for drinking.

Contamination attributable to the ashing process is characterized as contained within a small area on the site. This contamination is not affecting any of the domestic wells monitored at and adjacent to the site. Currently, there is no receptor population or individual. However, a future ground water use scenario for contaminated ground water originating from the former lignite ashing site is assumed for the purposes of this risk assessment. This scenario evaluates domestic ground water use consistent with current use by the rural population in the region. The potentially exposed population includes individuals of the following age groups: infants (birth to 1 year old); children ( 1 to 10 years old); and adults (11 to 64 years old). These age groups were selected for the following reasons:

- Survey data for population variables such as age, weight, and daily water intake are available for these age groups.

- Toxicological variables are similar within these age groups, including responsiveness of sensitive subgroups (infants and children) to the contaminants of concern, toxicant intake-to-body weight ratios, and toxicokinetics.

\subsection{EXPOSURE PATHWAYS}

Ground water is the primary source of water for southwestern North Dakota. Water for domestic use is predominantly obtained from the deep regional 
aquifers. The city of Belfield municipal water supply system retrieves ground water from three wells more than $1000 \mathrm{ft}(300 \mathrm{~m})$ deep. However, not all residents in the site vicinity are on city water, and domestic use of shallow ground water has been identified. Therefore, possible exposure pathways to site-contaminated shallow ground water include both direct exposure (through drinking and dermal contact) and indirect exposure (through ingestion of garden produce irrigated with contaminated ground water and ingestion of meat or milk from livestock watered with contaminated ground water). For this risk assessment, future exposure to the most contaminated ground water originating from the processing site is considered. Figure 4.1 provides a conceptual model for potential ground water exposure pathways at the Belfield site.

\subsubsection{Drinking water ingestion}

Given the chemical properties of the contaminants of potential concern, drinking water ingestion is generally the most significant exposure pathway for ground water contaminated with metals and other nonvolatile compounds. For this evaluation, drinking water consumption includes water consumed for drinking and water used in food preparation (e.g., reconstituted juices, soup, rice, and beans). For comparison of relative pathway significance, Table 4.1 is a screening level assessment of drinking water intake.

Screening calculations are based on the maximum concentration of contaminants of potential concern (from well 520). Water quality in the site vicinity has a diffuse and variable nature. Background and on-site water quality is influenced by temporal and spatial hydrochemical changes. Therefore, use of the maximum concentration is reasonable for estimating the upper range of potential exposure. This is a conservative assumption and may overestimate chronic exposure.

\subsubsection{Dermal absorption}

Dermal absorption is the process by which chemicals coming into contact with the skin are absorbed into the blood vessels near the skin surface. Some compounds are absorbed easily, although metals do not possess the chemical properties conducive to skin absorption.

To evaluate this exposure route, a screening calculation was performed to determine whether a dermal absorption pathway would be significant compared with the drinking water pathway for the contaminants of potential concern. Because chemical-specific absorption factors are not available for these contaminants, it was assumed that they are absorbed across the skin at the same rate as water. This assumption probably will overestimate any potential contribution from dermal absorption. The concentration in water was assumed to be the maximum detected concentration from the most contaminated well, which may overestimate chronic exposure from this pathway but more likely incorporates the upper range of potential exposure. 


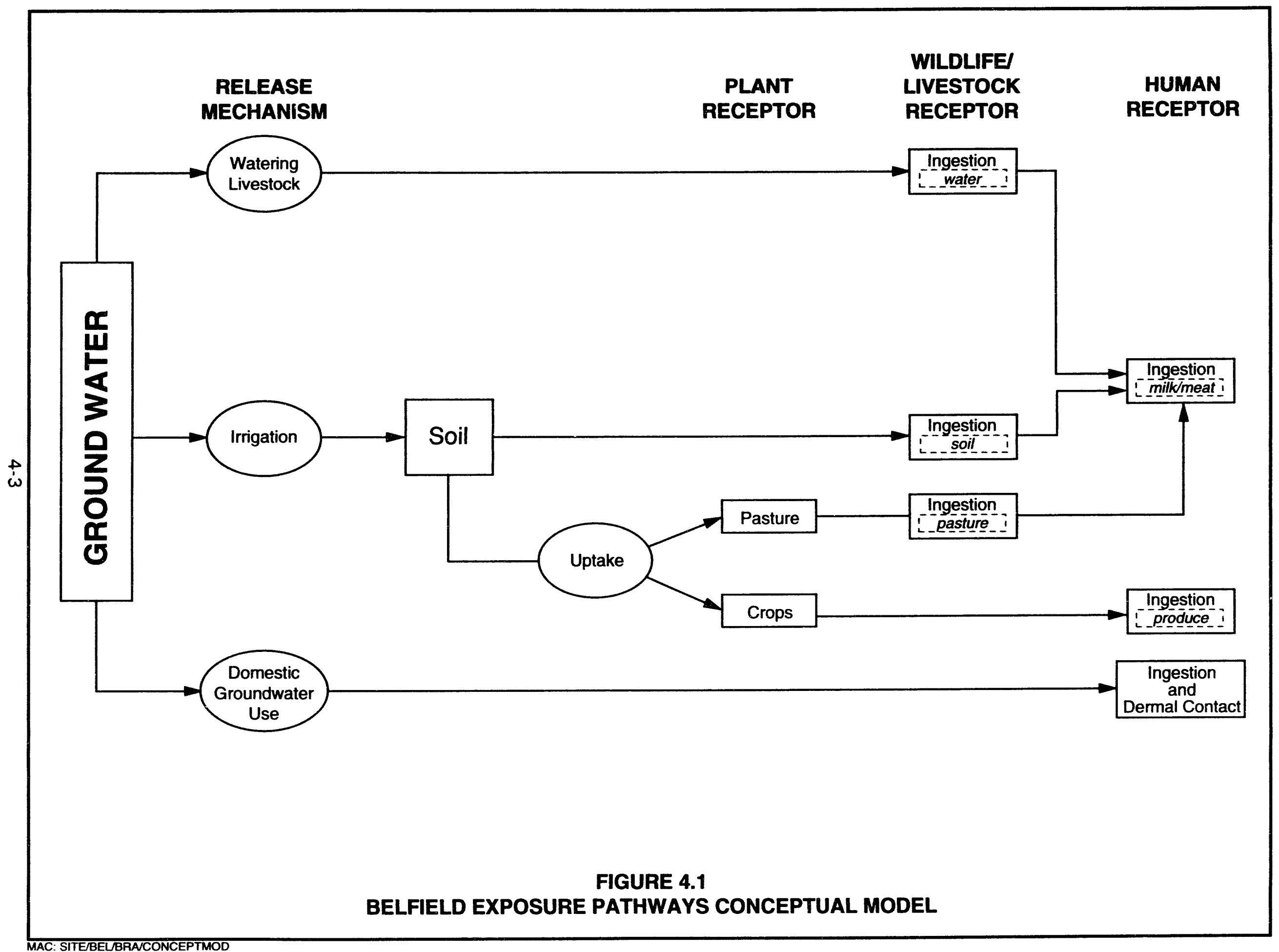


Table 4.1 Exposure dose calculations and equation definitions for ground water ingestion and dermal contact, Belfield UMTRA Project site, Belfield, North Dakota

\begin{tabular}{|c|c|c|c|c|}
\hline \multirow{2}{*}{$\begin{array}{c}\text { Contaminant of } \\
\text { potential } \\
\text { concern }\end{array}$} & \multirow[b]{2}{*}{ Cw } & \multicolumn{2}{|c|}{ Ground water exposure doses } & \multirow{2}{*}{$\begin{array}{l}\text { Ratio of } \\
\text { dermal contact: } \\
\text { ingestion }\end{array}$} \\
\hline & & Ingestion & Dermal contact & \\
\hline \multicolumn{2}{|c|}{ Noncarcinogenic effects (mg/L) } & \multicolumn{2}{|c|}{ (mg/kg-day) } & \\
\hline Uranium & 0.106 & $2.9 \mathrm{E}-03$ & $5.6 \mathrm{E}-06$ & 0.002 \\
\hline Vanadium & 0.100 & $2.7 E-03$ & $5.3 E-06$ & 0.002 \\
\hline \multicolumn{2}{|c|}{ Carcinogenic effects (pCi/L) } & \multicolumn{2}{|c|}{ (pCi/lifetime) } & \\
\hline Uranium $^{\mathbf{a}}$ & 73 & $2.6 E+06$ & $5.0 E+03$ & 0.002 \\
\hline
\end{tabular}

Equation definitions for exposure dose calculations Ingestion of ground water

\section{Noncarcinogens}

Chronic daily intake $\left(\mathrm{mg} / \mathrm{kg}\right.$-day) $=\frac{C W \times I R w \times E F \times E D}{B W \times A T}$

Radionuclides

Lifetime intake (pCi)

\section{Noncarcinogens}

Chronic daily intake ( $\mathrm{mg} / \mathrm{kg}$-day)

Radionuclides

Lifetime intake (pCi)

$=\quad C W \times S A \times P C \times C f \times E T \times E F \times E D$

where:

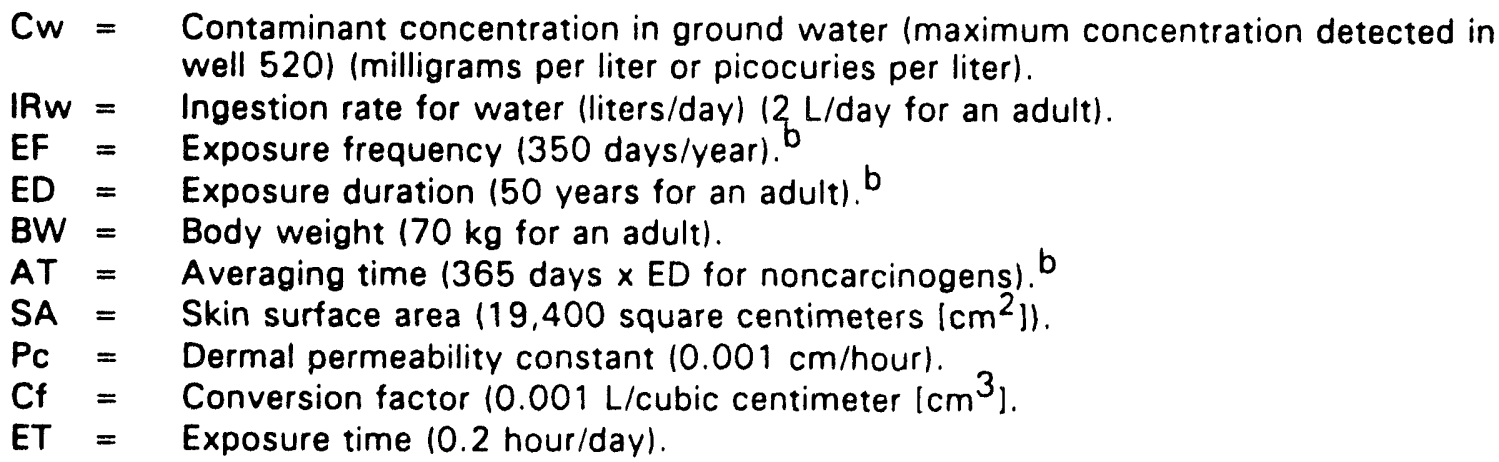

Uranium-234 and uranium-238 combined.

bEPA, 1991.

mg/kg-day - milligrams per kilogram per day.

$\mathrm{pCi} / \mathrm{L}$ - picocuries per liter. 
The results of the screening are given in Table 4.1. Although the dermal dose is an absorbed dose, whereas the ingested dose is a total dose of which only a percentage will be absorbed, the very low contribution of dermal absorption, ( 0.2 percent) is assumed to be insignificant compared to ingestion. Based on these results, the dermal absorption exposure route is eliminated from more detailed evaluation.

\subsubsection{Ingestion of ground water-irrigated produce}

This exposure route also was evaluated for its significance relative to the drinking water ingestion route. Table 4.2 presents the results of the screening calculation. This garden is assumed to be the source of all garden produce in the diet, which will overestimate the exposure potential from this route. The results of this screening show that for the contaminants of potential concern at this site, ingesting garden vegetables and fruit irrigated with contaminated ground water would contribute less than 1 percent of the total intake associated with drinking water ingestion. Thus, this pathway is eliminated from further evaluation.

\subsubsection{Ingestion of milk or meat from ground water-fed livestock}

The relative contribution from ingestion of milk from ground water-fed livestock is 1 percent or less of the exposure from drinking water for the contaminants of potential concern (Table 4.3). Ingestion of meat from these animals also would contribute less than 1 percent of the exposure anticipated from drinking water for all constituents (Table 4.4). The contribution from these sources is not included in the exposure simulations.

\subsubsection{Summary}

In summary, results of the screening calculations for water ingestion, dermal contact with water, and milk and meat ingestion indicate that drinking water ingestion is the most significant exposure pathway. The drinking water pathway is further evaluated probabilistically in the estimation of contaminant intakes (Section 4.4). Toxicity and potential adverse health effects relative to the anticipated intakes are addressed in Section 6.0.

\subsection{EXPOSURE CONCENTRATIONS}

The exposure concentration of a contaminant in ground water is that concentration contacted by an individual over the period of exposure being considered. In this evaluation, the contaminant concentrations are assumed to be in a steady state, although actual contaminant concentrations likely vary spatially and temporally. For example, contaminant concentrations are expected to decrease with time after site remediation. Nonetheless, these estimates are reasonable for chronic exposure under current conditions. Chronic exposure for noncarcinogens is considered to be exposure for any period longer than 7 years. 
Table 4.2 Exposure dose calculations and equation definitions for ingestion of ground water-irrigated garden produce, Belfield UMTRA Project site, Belfield, North Dakota

\begin{tabular}{|c|c|c|c|c|c|c|}
\hline $\begin{array}{c}\text { Contaminant } \\
\text { of potential } \\
\text { concern }\end{array}$ & $C_{w}$ & $\begin{array}{c}K d \\
(L / k g)\end{array}$ & Bv & $\mathrm{Br}$ & $\begin{array}{c}\text { Garden produce } \\
\text { ingestion exposure } \\
\text { doses }\end{array}$ & $\begin{array}{c}\text { Ratio of produce } \\
\text { ingestion:water } \\
\text { ingestion }\end{array}$ \\
\hline \multicolumn{5}{|c|}{ Noncarcinogenic effects $(\mathrm{mg} / \mathrm{L})$} & \multicolumn{2}{|l|}{ (m/kg-day) } \\
\hline Uranium & 0.106 & 50 & 0.0085 & 0.004 & $2.6 \mathrm{E}-06$ & 0.001 \\
\hline Vanadium & 0.100 & 100 & 0.0055 & 0.003 & 3.3E-06 & 0.001 \\
\hline \multicolumn{4}{|c|}{ Carcinogenic effects (pCi/L) } & \multicolumn{3}{|c|}{ (pCi/lifetime) } \\
\hline Uranium & 73 & 50 & 0.0085 & 0.004 & $2.3 E+03$ & 0.001 \\
\hline
\end{tabular}

Equation definitions for exposure dose calculations

Ingestion of garden produce irrigated with ground water

Noncarcinogens

Chronic daily intake $(\mathrm{mg} / \mathrm{kg}$-day)

$\frac{C W \times K d \times B v(o r B r) \times D F \times \mid R p \times F I \times E F \times E D}{B W \times A T}$

Radionuclides

Lifetime intake (pCi)

$=\quad \mathrm{CW} \times \mathrm{Kd} \times(\mathrm{Bv}$ or $\mathrm{Br}) \times \mathrm{DF} \times \mathrm{IRp} \times \mathrm{FI} \times \mathrm{EF} \times \mathrm{ED}$

where:

$\mathrm{Cw}=$ Contaminant concentration in ground water (maximum concentration detected) (milligrams per liter or picocuries per liter).

Kd = Soil-water partition coefficient (liters per kilogram); from Pacific Northwest Laboratory (PNL), 1989.

$\mathrm{Bv}=$ Soil-to-plant concentration ratio for vegetative portions of plants (unitless). ${ }^{\mathrm{b}}$

$\mathrm{Br}=$ Soil-to-plant concentration ratio for reproductive portions (fruits, tubers) of plants (unitless).

DF = Dry weight fraction of plant $(0.066$ unitless $)$.

$\mathbb{R p}=$ Ingestion rate for garden produce $10.05 \mathrm{~kg} /$ day for vegetative parts; $0.03 \mathrm{~kg} /$ day for reproductive parts).

$\mathrm{FI}=$ Fraction of garden produce ingested from contaminated source (1.0 unitless). ${ }^{b}$

$E F=$ Exposure frequency (350 days/year).

$E D=$ Exposure duration ( 50 years for an adult).

$B W=$ Body weight $(70 \mathrm{~kg}$ for an adult).

AT = Averaging time (365 days $\times$ ED for noncarcinogens).

${ }^{a}$ Exposure doses shown are the sum of the vegetative parts plus the reproductive parts.

baes, 1984 
Table 4.3 Exposure dose calculations and equation definitions for ingestion of milk from ground water-fed livestock, Belfield UMTRA Project site, Belfield, North Dakota

\begin{tabular}{|c|c|c|c|c|c|c|}
\hline $\begin{array}{l}\text { Contaminant } \\
\text { of potential } \\
\text { concern }\end{array}$ & $C_{w}$ & $\begin{array}{c}K d \\
(L / k g)\end{array}$ & Bv & $\mathrm{Fm}$ & $\begin{array}{l}\text { Milk ingestion } \\
\text { exposure doses }\end{array}$ & $\begin{array}{l}\text { Ratio of milk } \\
\text { Ingestion:water } \\
\text { ingestion }\end{array}$ \\
\hline \multicolumn{4}{|c|}{ Noncarcinogenic effects $(\mathrm{mg} / \mathrm{L})$} & & \multicolumn{2}{|l|}{ (mg/kg-day) } \\
\hline Uranium & 0.106 & 50 & 0.0085 & 0.0006 & $2.2 \mathrm{E}-05$ & 0.0076 \\
\hline Vanadium & 0.100 & 100 & 0.0055 & 0.00002 & $8.5 \mathrm{E}-07$ & 0.0003 \\
\hline \multicolumn{4}{|c|}{ Carcinogenic affects (pCi/L) } & \multicolumn{3}{|c|}{ (pCi/lifetime) } \\
\hline Uranium & 73 & 50 & 0.0085 & 0.0006 & $1.9 E+04$ & 0.0073 \\
\hline
\end{tabular}

Equation definitions for exposure dose calculations

Ingestion of milk from ground water-fed livestock

Noncarcinogens

Chronic daily intake $(\mathrm{mg} / \mathrm{kg}$-day)

$$
\begin{aligned}
& =\frac{\mathrm{Cm} \times \mathrm{IRm} \times \mathrm{FI} \times \mathrm{EF} \times \mathrm{ED}}{B W \times A T} \\
& =\quad \mathrm{Cm} \times \mathrm{IRm} \times \mathrm{FI} \times \mathrm{EF} \times \mathrm{ED}
\end{aligned}
$$

Radionuclides

Lifetime intake ( $p C i)$

where:
$\mathrm{Cm}=$
Contaminant concentration in milk (milligrams per liter), estimated using the following equation:
where
$\mathrm{Cm}=\mathrm{Fm} \times([\mathrm{Qp} \times \mathrm{Cp}]+[\mathrm{Q} s \times \mathrm{Cs}]+[\mathrm{Qw} \times \mathrm{Cw}])$
$\mathrm{Fm}=$ Feed-to-milk transfer coefficient (days/kilogram). ${ }^{\mathrm{a}}$
$\mathrm{Qp}_{\mathrm{p}}=$ The quantity of pasture eaten by cattle per day $(19 \mathrm{~kg} / \mathrm{day}) \mathrm{a}^{\mathrm{a}}$
Qs $=$ The quantity of soil eaten by cattle per day $(0.38 \mathrm{~kg} /$ day $) .^{\text {a }}$
$\mathrm{Q}_{w}=$ The quantity of water consumed by cattle per day $(56 \mathrm{~L} /$ day $) .^{a}$
$C_{p}=$ Contaminant concentration in pasture (milligrams per kilogram).
$\mathrm{Cp}=\mathrm{Kd} \times \mathrm{Cw} \times \mathrm{Bv}$.
$\mathrm{Cs}=$ Contaminant concentration in soil (milligrams per kilogram). Cs $=\mathrm{Kd} \times \mathrm{Cw}$.
$\mathrm{Cw}=$ Contaminant concentration in ground water (maximum concentration detected) (milligrams per liter or picocuries per liter).
Kd $=$ Soil-water partition coefficient (liters per kilogram); from PNL, 1989.
$\mathrm{Bv}=$ Soil-to-plant concentration ratio for vegetative portions of plants (unitless). ${ }^{a}$
$\mathrm{EF}=$ Exposure frequency ( 350 days/year).
$E D=$ Exposure duration (50 years for an adult).
BW = Body weight $(70 \mathrm{~kg}$ for an adult $)$.
$A T=$ Averaging time ( 365 days $\times$ ED for noncarcinogens).
$\mid R m=$ Ingestion rate of milk $(0.3 \mathrm{~kg} /$ day $)$.
$\mathrm{FI}=$ Fraction of milk ingested from contaminated source (1.0 unitless) ${ }^{\mathrm{a}}$

Baes, 1984. 
Table 4.4 Exposure dose calculations and equation definitions for ingestion of meat from ground water-fed livestock, Belfield UMTRA Project site, Belfield, North Dakota

\begin{tabular}{|c|c|c|c|c|c|c|}
\hline $\begin{array}{c}\text { Conteminant } \\
\text { of potential } \\
\text { concern }\end{array}$ & Cw & $\begin{array}{c}K d \\
(L / K g)\end{array}$ & Bv & $\mathbf{F f}$ & $\begin{array}{l}\text { Meat ingestion } \\
\text { exposure doses }\end{array}$ & $\begin{array}{l}\text { Ratio of } \\
\text { meat ingestion: } \\
\text { water ingestion }\end{array}$ \\
\hline \multicolumn{4}{|c|}{ Noncercinogenic effects $(\mathrm{mg} / \mathrm{L})$} & & \multicolumn{2}{|l|}{ (mg/kg-day) } \\
\hline Uranium & 0.106 & 50 & 0.0085 & 0.0002 & $1.8 \mathrm{E} \cdot 06$ & 0.0006 \\
\hline Vanadium & 0.10 & 100 & 0.0055 & 0.0025 & $2.7 \mathrm{E} \cdot 05$ & 0.01 \\
\hline \multicolumn{4}{|c|}{ Carcinogenic offects $(\mathrm{pCl} / \mathrm{L})$} & \multicolumn{3}{|c|}{ (pCi/lifetime) } \\
\hline Uranium & 73 & 50 & 0.0085 & 0.0002 & 1600 & 0.0006 \\
\hline
\end{tabular}

\section{Equation definitions for exposure dose calculations}

Ingestion of meat from ground water-fed livestock

\section{Noncarcinogens}

Chronic daily intake $(\mathrm{mg} / \mathrm{kg} \cdot$ day)

$$
=\frac{C b \times I R b \times F I \times E F \times E D}{B W \times A T}
$$

Radionuclides

Lifetime intake (pCi)

$=\quad C b \times I R b \times F I \times E F \times E D$

where:

$\mathrm{Cb}=$ Contaminant concentration in beef (milligrams per kilogram), estimated using the following equation:

where

$$
\mathrm{Cb}=\mathrm{Ff} \times([\mathrm{Op} \times \mathrm{Cp})+10 \mathrm{~s} \times \mathrm{Cs}]+[0 w \times C w])
$$

Ff = Feed-to-flesh transfer coefficient (days/kilogram). ${ }^{a}$

$Q_{p}=$ The quantity of pasture eaten by cattle per day $(19 \mathrm{~kg} / \mathrm{day})$. $^{a}$

Qs = The quantity of soil eaten by cattle per day $(0.38 \mathrm{~kg} /$ day $)$. $^{\text {a }}$

$\mathrm{Q}_{w}=$ The quantity of water consumed by cattle per day $(56 \mathrm{~L} /$ day $)$. $^{a}$

$\mathrm{Cp}_{\mathrm{p}}=$ Contaminant concentration in pasture (milligrams per kilogram). $\mathrm{Cp}=\mathrm{Kd} \times \mathrm{Cw} \times$

Bv.

$\mathrm{Cs}=$ Contaminant concentration in soil (milligrams per kilogram). Cs $=\mathrm{Kd} \times \mathrm{CW}$.

$\mathrm{Cw}=$ Contaminant concentration in ground water (maximum concentration detected) (milligrams per liter or picocuries per liter).

Kd = Soil-water partition coefficient (liters per kilogram); from PNL, 1989, except for

uranium. The $\mathrm{Kd}$ for uranium is a site-specific value.

Bv = Soil-to-plant concentration ratio for vegetative portions of plants (unitless). ${ }^{a}$

$E F=$ Exposure frequency (350 days/year).

$E D=$ Exposure duration (50 years for an adult).

$B W=$ Body weight $(70 \mathrm{~kg}$ for an adult).

$A T=$ Averaging time (365 days $\times$ ED for noncarcinogens)

IRb = Ingestion rate of meat $(0.075 \mathrm{~kg} /$ day $)$.

$\mathrm{FI}=$ Fraction of meat ingested from contaminated source (1.0 unitless). ${ }^{a}$

\section{Baes, 1989.}


Exposure concentrations are evaluated as a probability of occurrence based on ground water data collected from monitor well 520 for the contaminants of potential concern. This well is located on-site where ashing took place, directly adjacent to the area used to store raw lignite. Well 520 has consistently shown the highest concentrations of most constituents.

Theoretical probability distributions were prepared for the two inorganic constituents of potential concern in the upper zone (sandy clay layer). The software package @RISK (Palisade Corp., 1992) was used to generate these distributions. Each distribution selected had approximately the same mean, median, standard deviation, and shape as those observed in the historical water quality data. The upper tails of the distributions were truncated at the 99th percentile. This truncation is conservative since, for every contaminant, the highest concentration in the distribution was higher than the maximum observed concentration in the historical water quality data.

Vanadium data showed no marked trend in concentration over time, so the distribution was derived giving equal weight to all vanadium measurements recorded for well 520. The theoretical distribution selected reflects the same average, spread, and general shape as the actual water quality measurements (Figure 4.2).

Uranium data showed an increasing trend over time (Figure 3.2). The trend was estimated and the resulting distribution is centered over the more recently occurring values (Figure 4.3). The variability in the theoretical distribution reflects the random variation of the historical data around the trend line. It is explicitly assumed that uranium concentrations for the next few years will not continue to climb but will stabilize around the levels last observed in well 520 . This is the most conservative methodology possible without more information.

\subsection{ESTIMATION OF INTAKE}

Within the population of current and future residents, individuals are expected to vary with respect to water consumption, stable body weight, and time of residence in the potential contamination zone. Consequently, health risks associated with ground water consumption will vary among members of this population. To adequately describe the range of potential future risks to the population, naturally occurring variability in daily water intake and body weight were incorporated in this assessment through probability distributions generated from U.S. public health and census data. All distributions were truncated at the upper and lower 0.01 percentile. Within the hypothetical population, values disallowed through this truncation may occur with a probability of less than 1 in 10,000 .

The potential toxicity of noncarcinogenic contaminants in drinking water depends primarily on long-term average daily consumption (i.e., at least 7 years) of the contaminant per kilogram of body weight measured in milligrams per kilogram per day (mg/kg-day). For intake of noncarcinogens, exposure 


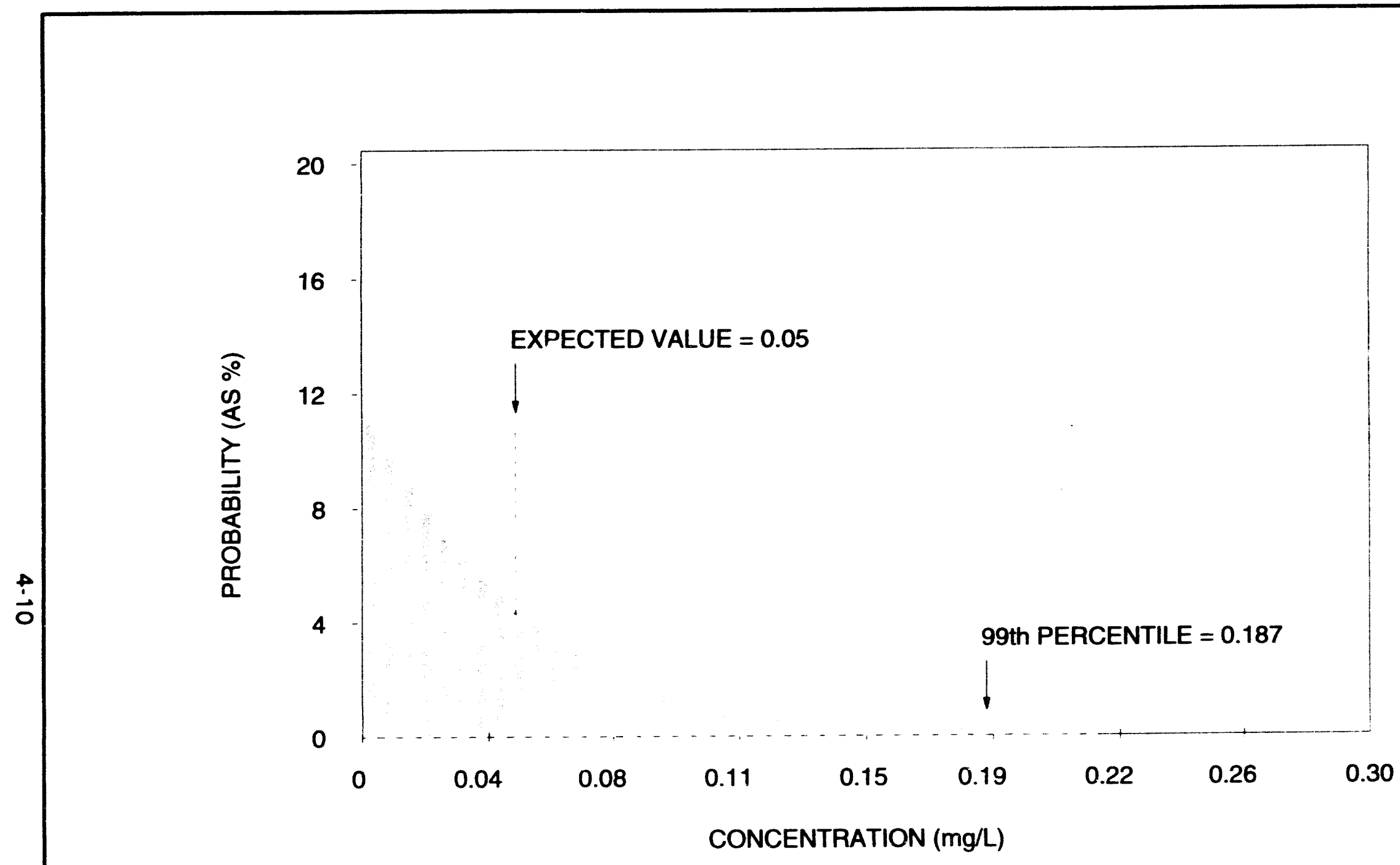

FIGURE 4.2

SIMULATED DISTRIBUTION OF VANADIUM CONCENTRATIONS

BELFIELD, NORTH DAKOTA, SITE 


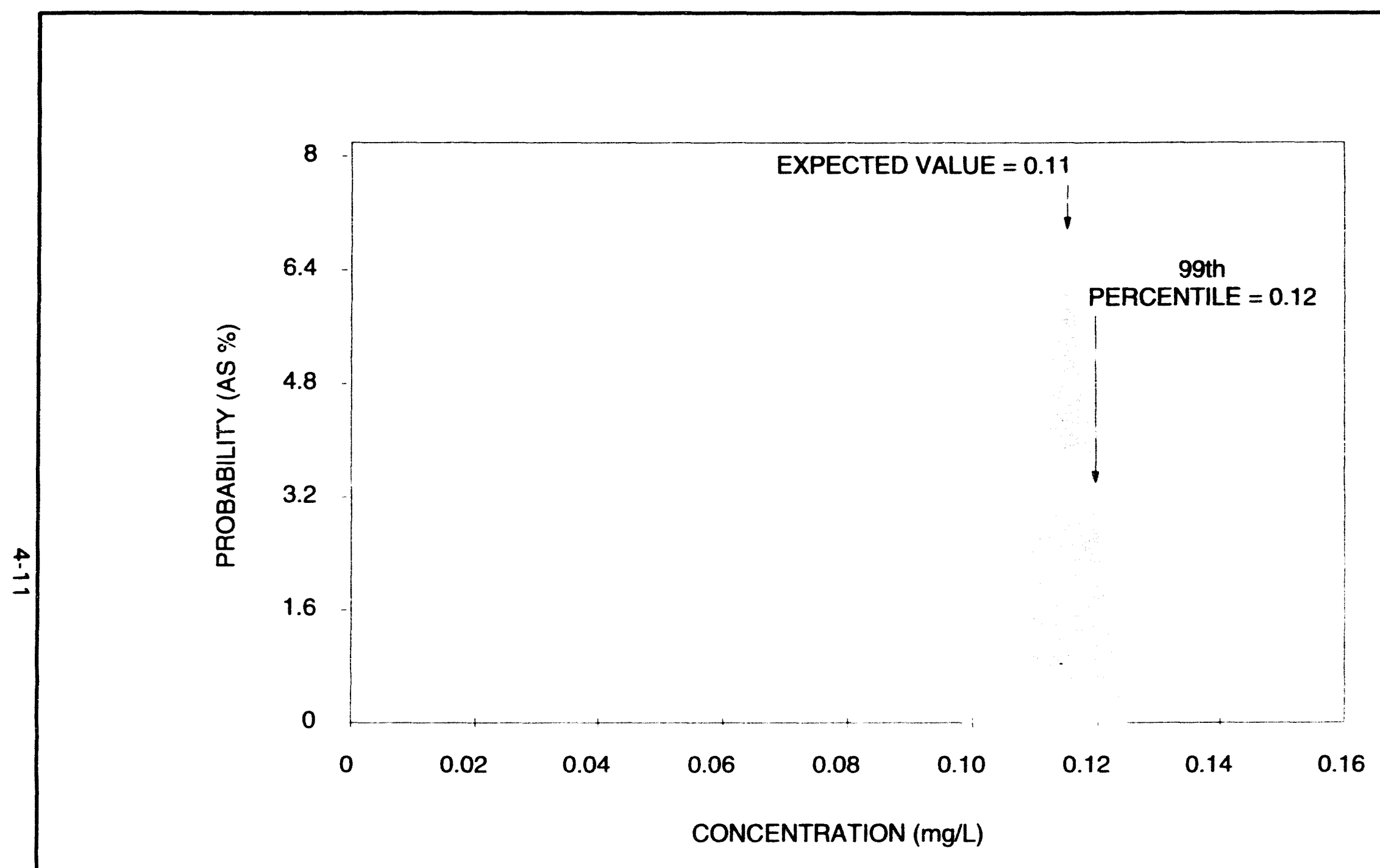

FIGURE 4.3

SIMULATED DISTRIBUTION OF URANIUM CONCENTRATIONS BELFIELD, NORTH DAKOTA, SITE

PATH I:IFL 3. ONBELBRA

URANCONC. DAW 
frequency times exposure duration in the numerator is averaged over 365 days times the exposure duration in the denominator, and taking body weight into consideration. The following equation is used to calculate chronic daily intake:

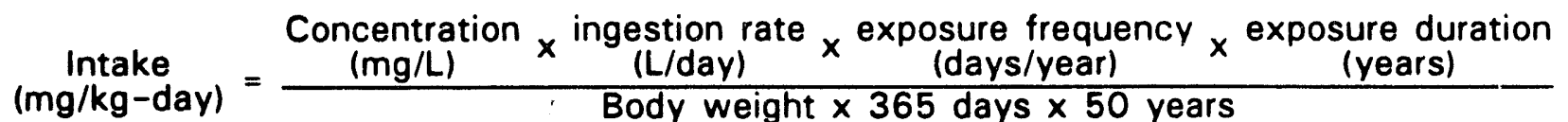

Potential carcinogenicity increases with total intake over time, as compared to average daily intake for noncarcinogens. Also, body weight is relatively insignificant in determining risk from exposure to carcinogens. The only carcinogen elevated above background at the Belfield site is uranium, which is a carcinogen because of its radioactivity rather than its chemical properties. Intake of a radioactive carcinogenic substance is quantified as total exposure (measured in picocuries [pCi]) to radioactivity throughout the residency period of an individual:

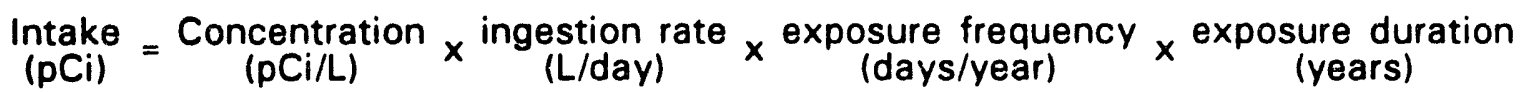

\section{Average daily intake (liters per day)}

Lognormal probability distributions were used to describe variations in average daily tap water intake among members of the population (Roseberry and Burmaster, 1992). These distributions were developed from data collected during a 1977-1978 food consumption survey conducted nationwide by the U.S. Department of Agriculture. During the survey, total tap water consumption during a 3-day period was recorded for 26,081 survey participants nationwide (Figure 4.4).

\section{Body weight (kilograms)}

Extensive national data on weights of males and females, by age, were collected by the National Health and Nutrition Survey between 1976 and 1980 . These data were used to develop lognormal probability distributions for body weight by age for each sex. The distributions for males and females were then combined using census data on the national ratio of males to females within each age yroup (Figure 4.5).

\section{Exposure duration (vears)}

For noncarcinogenic effects, the exposure duration of 50 years averaged over 1 year times the exposure duration for drinking water intake effectively cancel each other out (see the equation for chronic daily intake of noncarcinogens in Table 4.1). However, for carcinogens, exposure duration directly affects intake results. A fixed lifetime exposure of 50 years was used to model lifetime 

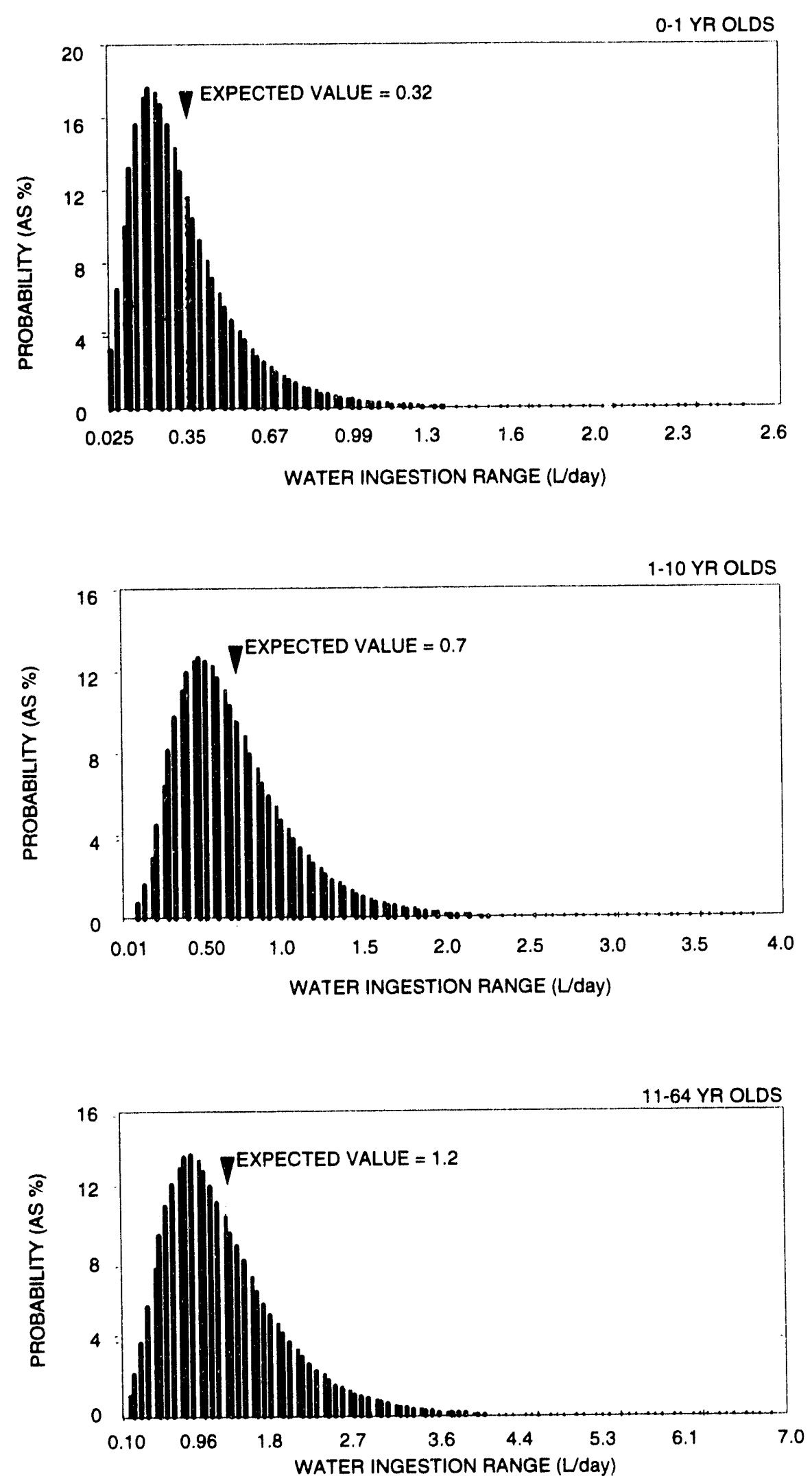

FIGURE 4.4

PROBABILITY DISTRIBUTIONS FOR TAP WATER INGESTION RATES 


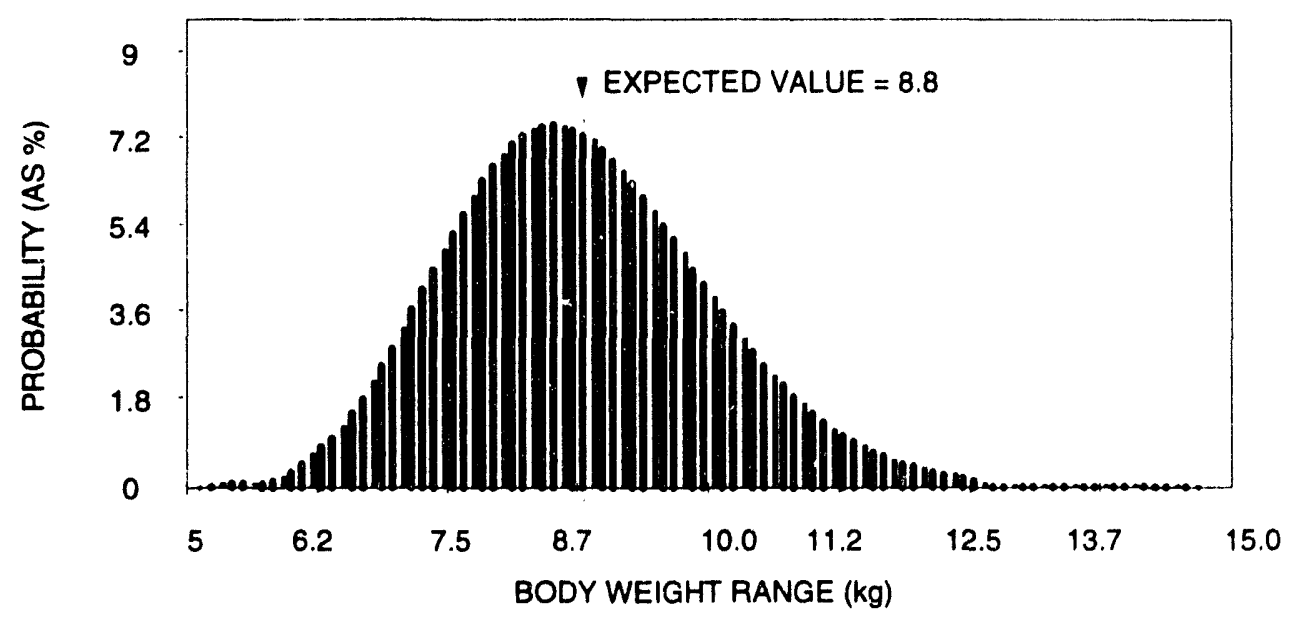

1-10 YR OLDS

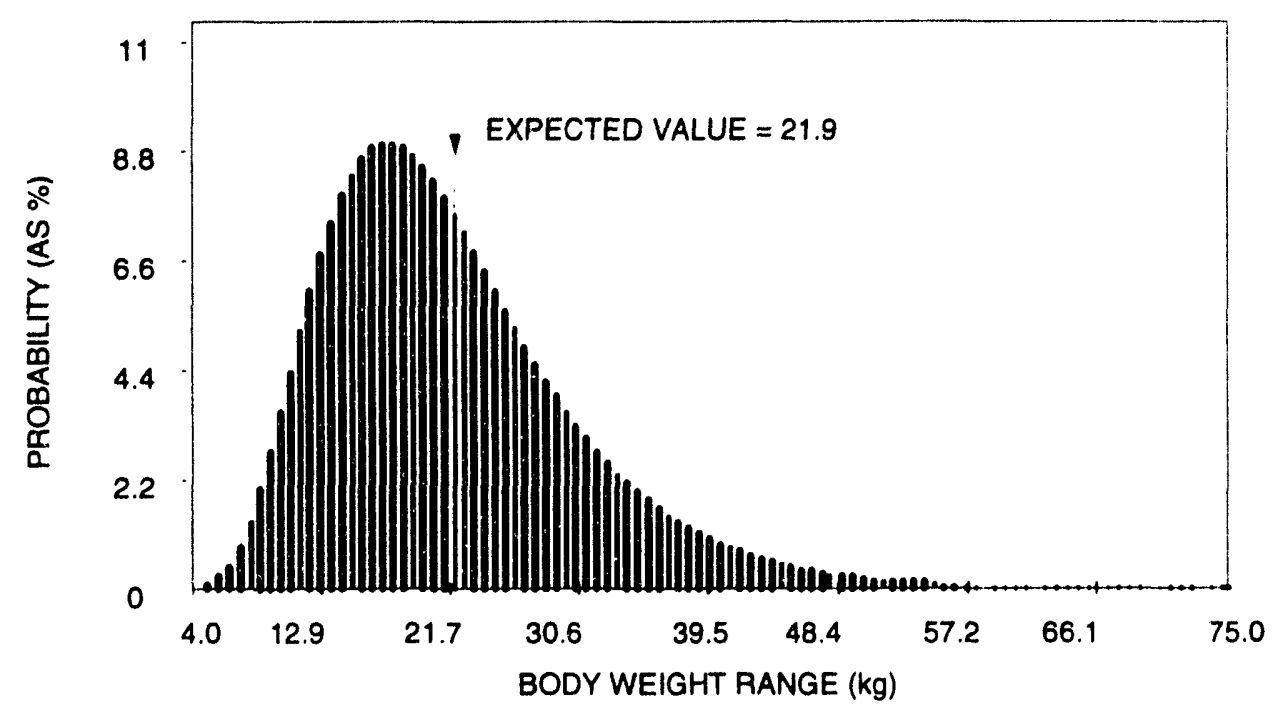

11.64 YR OLDS

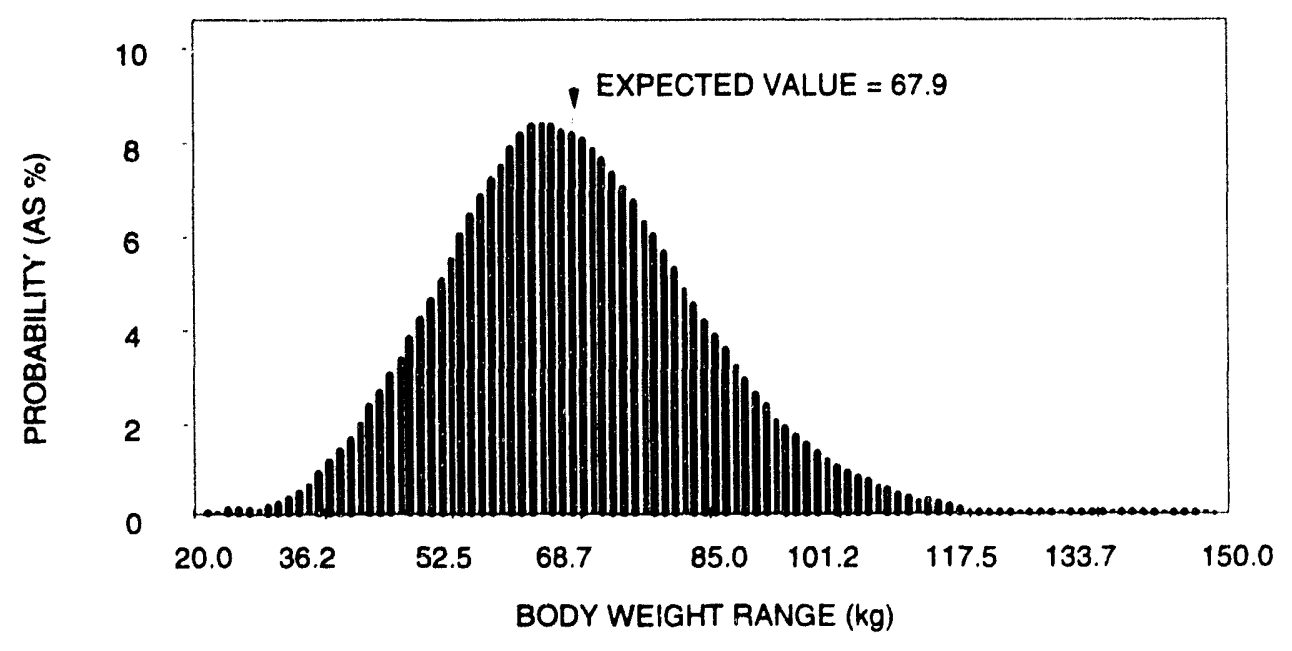

FIGURE 4.5

PROBABILITY DISTRIBUTIONS FOR BODY WEIGHT 
cancer risks to take into account the rural nature of the Belfield area and the likelihood of a longer average residency time.

\section{Exposure frequency (days per year)}

An exposure frequency of 350 days per year was assumed for a person exposed to contaminants in ground water. This estimates 15 days per year where the person is away from home and not in contact with the contaminants.

Using exposure concentration distributions discussed in Section 4.3 and the intake parameter distributions from this section, total intake distributions were simulated for the three populations. The 1-to 10-year-old age group consistently showed the highest intake-to-body-weight distributions and is therefore the most conservative age group to evaluate. No specific age group is known to have increased sensitivity to vanadium or uranium. Therefore, the 1 to 10-year-old age group was used in the risk evaluation. These results are shown in Figures 4.6 and 4.7 for noncarcinogens. The total lifetime intake estimate used to calculate carcinogenic risk from uranium is presented in Section 6.2 (Table 6.1).

\subsection{EXPOSURE ASSESSMENT UNCERTAINTIES}

A number of potential sources of error may arise in all phases of the exposure assessment, including the following more significant sources of uncertainty:

- Uncertainties resulting from the lack of thorough environmental sampling data (ground water, surface water, sediment, and biota), which could lead to an underestimate or overestimate in the exposure analysis.

- Uncertainties arising from the assumption that the ground water contaminant source term at the site has reached a steady state and that contaminant concentrations at the exposure point will remain constant for chronic periods of exposure (generally greater than 7 years).

- Uncertainties associated with the model used to estimate uptake of contaminants into plants for the irrigated garden produce pathway. Site-specific plant uptake factors could vary substantially from the default literature estimates.

- Uncertainties associated with meat transfer coefficients for the milk and meat ingestion pathways. Site-specific transfer coefficients could vary substantially from the default literature values.

- Uncertainties associated with the relationship of an applied dose (used in this assessment) and absorbed dose or effective toxic dose for dermal absorption. 


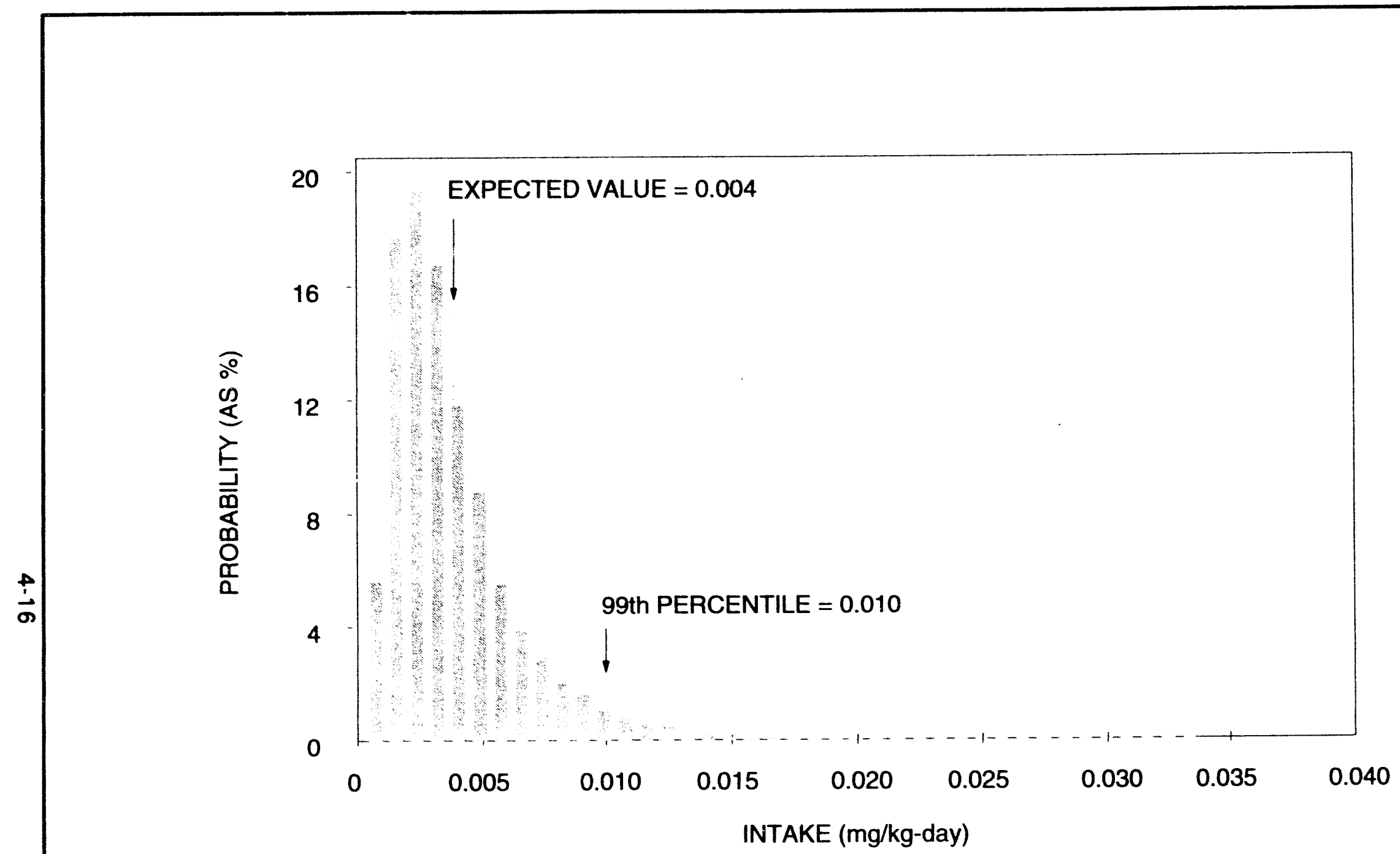

NOTE: EXPOSURES FOR CHILDREN HAVE BEEN MODELED BECAUSE THEIR INTAKE/kg BODY WEIGHT IS GREATEST AND NO SENSITIVE POPULATION HAS BEEN IDENTIFIED.

FIGURE 4.6

PROBABILITY DISTRIBUTION OF URANIUM INTAKES FOR CHILDREN

AS A RESULT OF GROUND WATER INGESTION

BELFIELD, NORTH DAKOTA, SITE 


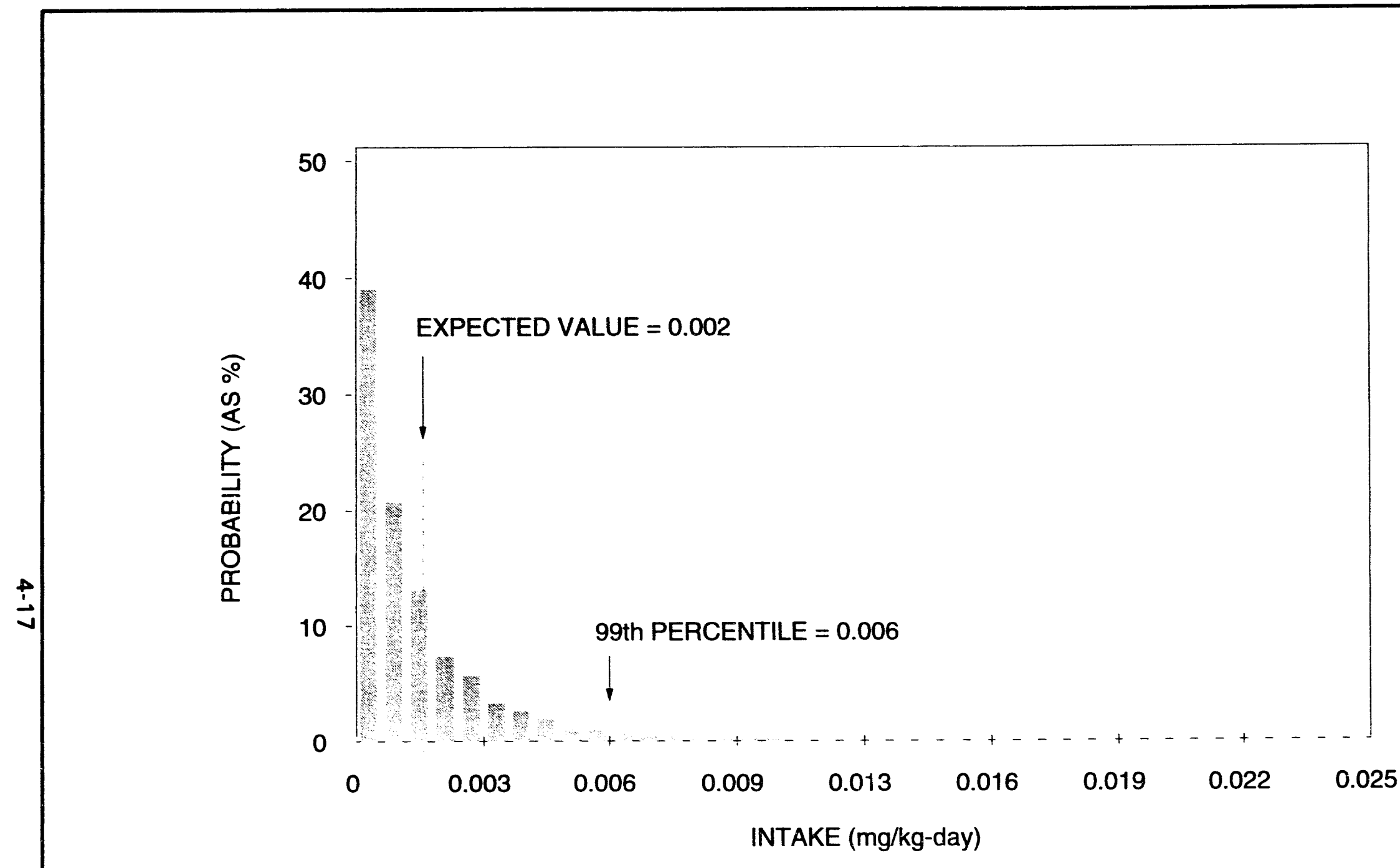

NOTE: EXPOSURES FOR CHILDREN HAVE BEEN MODELED BECAUSE THEIR INTAKE/kg BODY WEIGHT IS GREATEST AND NO SENSITIVE POPULATION HAS BEEN IDENTIFIED.

FIGURE 4.7

PROBABILITY DISTRIBUTION OF VANADIUM INTAKES FOR CHILDREN AS A RESULT OF GROUND WATER INGESTION

BELFIELD, NORTH DAKOTA, SITE 
- Uncertainties associated with differing sensitivities of subpopulations, such as individuals with chronic illnesses, that could alter predicted responses to contaminants.

Despite these uncertainties, the use of probability distributions that help to incorporate definable sources of variability should provide a representative picture of the potential range of exposures. 


\subsection{TOXICITY ASSESSMENT}

Two site-related contaminants in ground water, uranium and vanadium, have the potential to cause adverse human health and environmental effects above those potentially caused by naturally poor quality ground water. This section summarizes the toxicological effects of these chemical contaminants and the carcinogenic potentials of uranium and its longerlived radioactive decay progeny. Source materials used to develop these toxicological profiles include, when available, the EPA'S IRIS; ATSDR toxicological profiles, published by the Department of Health and Human Services (DHHS); the Handbook on the Toxicology of Metals (Friberg et al., 1986); and peer-reviewed scientific literature as cited when these review documents were not available. By basing toxicity information on the standard review documents cited above, evaluations at UMTRA Project sites should be consistent with evaluations at sites regulated under different legislation.

The toxicity profiles presented here will focus on drinking water source material for humans whenever available; animal information will be used only if human data are not available. Animal information on the toxicity range graphs will be represented by widely spaced dotted lines. When uncertainty exists about the beginning or ending points of a range of exposures producing specific toxic effects, closely spaced dots will be used at the appropriate end of the line denoting range.

\subsection{CONTAMINANT TOXICITY SUMMARIES}

The following summaries address the basic toxicokinetics and toxicity of vanadium and uranium as noncarcinogenic contaminants of potential concern at the Belfield site, based on the preliminary screening discussed previously. Wherever possible, data from human studies are reported. Although these contaminants have a wide range of toxic effects depending on the exposure levels, the following discussions focus most heavily on toxic effects observed in the exposure ranges most relevant to contamination at Belfield.

\subsubsection{Uranium}

Naturally occurring uranium, present at UMTRA Project sites, consists of three radioactive isotopes: uranium-234, uranium-235, and uranium-238. More than 99 percent of natural uranium occurs in the form of uranium-238 (Cothern and Lappenbusch, 1983). Uranium-238 undergoes radioactive decay by emitting alpha particles to form uranium-234, thorium-230, radium-226, radon-222, polonium-210, and other radioisotopes. Figure 5.1 illustrates the radioactive decay chain of uranium-238 and uranium-234. Because all uranium isotopes in nature are radioactive, the hazards of a high uranium intake are its chemical toxicity and potential radiological damage. This section focuses on the chemical toxicity of natural uranium. Section 5.3 discusses carcinogenic potential associated with exposure to radioactive isotopes of natural uranium. 


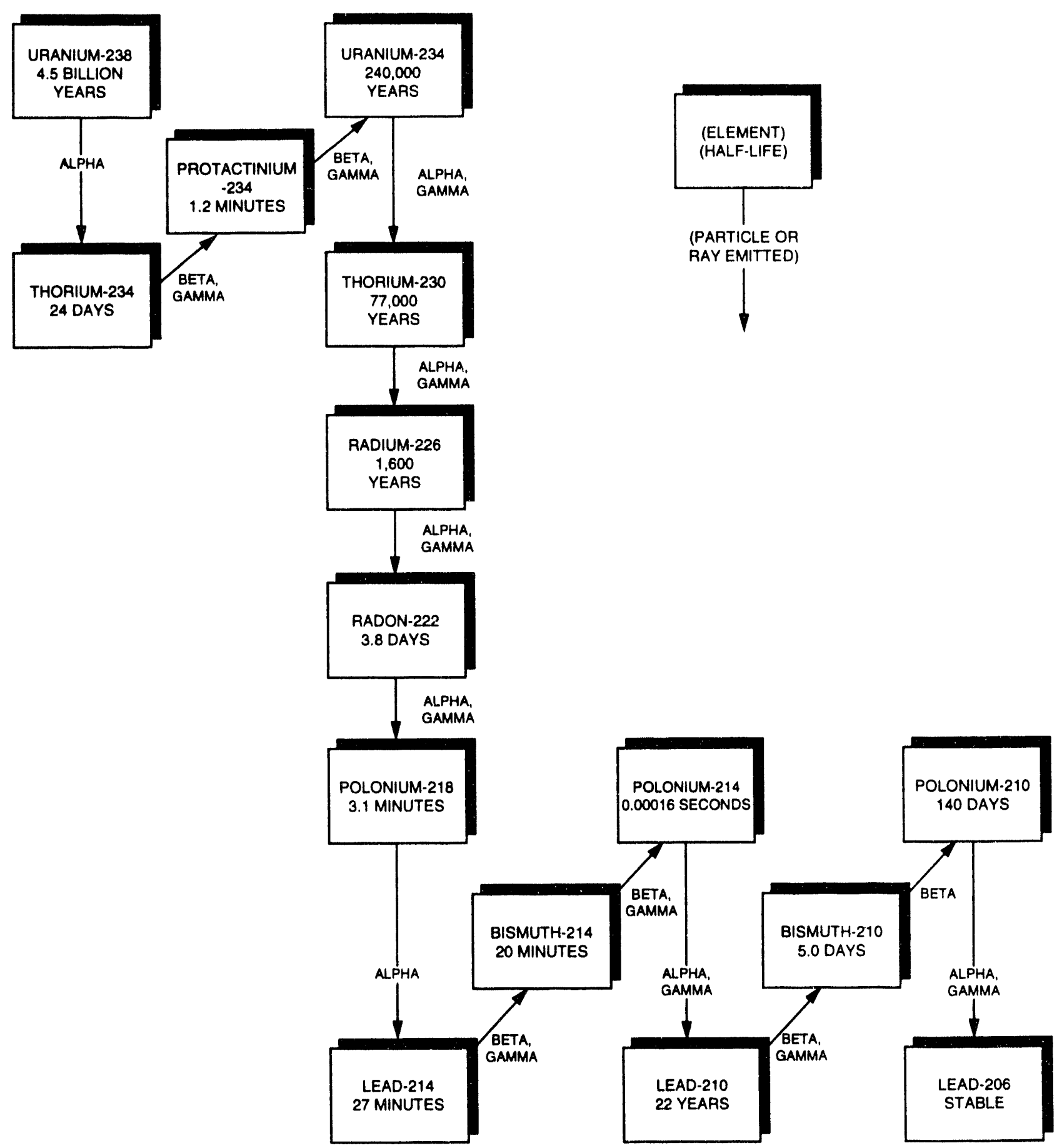

FIGURE 5.1

HALF-LIVES AND EMISSIONS FROM DECAY CHAIN OF URANIUM-238 


\section{Absorption}

Uranium absorption in the gastrointestinal tract depends on the solubility of the uranium compounds. The hexavalent uranium compounds, especially the uranyl salts, are water soluble, while tetravalent compounds generally are not (Weigel, 1983). Even with soluble compounds, only a small fraction is absorbed. Human gastrointestinal absorption rates of 0.76 to 7.8 percent have been determined (Wrenn et al., 1985).

\section{Tissue accumulation and clearance}

In humans exposed to background levels of uranium, the highest concentrations of uranium were found in the bone, muscle, lung, liver, and kidney (Fisenne et al., 1988). There are two components to the retention of uranium in the bone: a short retention half-time of 20 days followed by a long retention half-time of 5000 days (Tracy et al., 1992).

In body fluids, uranium tends to convert into water-soluble hexavalent uranium (Berlin and Rudell, 1986). Approximately 60 percent of the uranium in plasma complexes with low-molecular-weight anions (e.g., bicarbonates, citrates), while the remaining 40 percent binds to the plasma protein transferrin (Stevens et al., 1980). Following oral exposure in humans, more than 90 percent of uranium not absorbed from the gastrointestinal tract is excreted in the feces. Of the small percent that is absorbed (typically less than 5 percent), approximately 60 percent and 98 percent are excreted in the urine within 24 hours and 7 days, respectively, based on animal studies (Ballou et al., 1986; Leach et al., 1984; Sullivan et al., 1986). A small portion of the absorbed uranium is retained for a longer period.

\section{Environmental sources of uranium}

Uranium is a ubiquitous element, present in the earth's crust at approximately 4 parts per million. Uranium concentrations in ground water and surface water averaged 1 picocurie per liter ( $\mathrm{pCi} / \mathrm{L}$ ) and $3 \mathrm{pCi} / \mathrm{L}$, respectively (NCRP, 1984). It is absorbed from the soil into plant tissues to an extent that depends on the plant species and the depth of its root system (Berlin and Rudell, 1986). Plant concentrations of uranium averaged 0.075 micrograms per kilogram $(\mu \mathrm{g} / \mathrm{kg})$ of fresh plant material (Tracy et al., 1983).

The main source of uranium for the general population is food products such as potatoes, bakery products, meat, and fresh fish, which may contain uranium concentrations between 10 and $100 \mu \mathrm{g} / \mathrm{kg}$ (Prister, 1969). The total dietary intake of uranium from the consum.ption of average foods is approximately 1 microgram $(\mu \mathrm{g})$ per day. Cereals and vegetables, particularly root crops, are likely to contribute most to daily uranium intake (Berlin and Rudell, 1986). 


\section{Toxicity of uranium}

Exposure of the general public to natural uranium is unlikely to pose an immediate lethal threat to humans. No human deaths have been reported to be definitely attributable to uranium exposure. Lethal doses in animals range from 8 to 242 milligrams per kilogram $(\mathrm{mg} / \mathrm{kg})$, depending on the solubility of the uranium compound tested (higher solubility compounds have greater toxicity) and animal species. High doses of uranium cause complete kidney and respiratory failure.

No chronic toxic effects have been reported in humans following oral exposure to uranium. Data available from populations occupationally exposed to high concentrations of uranium compounds through inhalation and information from studies in experimental animals indicate that the critical organ for chronic uranium toxicity is the proximal tubule of the kidney (Friberg et al., 1986). In humans, chemical injury reveals itself by increased catalase excretion in urine and proteinuria. Dose-response data for the toxic effect of uranium on the human kidney are limited.

The lowest dose of uranyl nitrate to cause moderate renal damage was given to rabbits in diet at $2.8 \mathrm{mg} / \mathrm{kg}$-day (Maynard and Hodge, 1949). Figure 5.2 summarizes the health effects for uranium as a function of dose.

\subsubsection{Vanadium}

\section{Absorotion}

Absorption of vanadium from the gastrointestinal tract is low. The ICRP (1960) estimate for the absorption of soluble vanadium compounds is 2 percent, but the World Health Organization states that absorption of even very soluble forms of vanadium is less than 1 percent from the gastrointestinal tract (WHO,1988). Limited human studies (three individuals) have suggested that as much as 10 percent of a repeated oral dose may be absorbed (Proescher et al., 1917; Tipton et al., 1969). Soluble vanadium compounds that are inhaled and deposited are more readily absorbed (approximately 25 percent) (WHO, 1988). Although soluble forms of vanadium may be absorbed through the skin, absorption through the skin is probably minimal (EPA, 1977; WHO, 1988).

\section{Tissue accumulation and clearance}

Vanadium is found in all body tissues in concentrations ranging from $0.08 \mu \mathrm{g}$ per gram wet weight in spleen tissue to $0.14 \mu \mathrm{g}$ per gram in brain and heart tissue and $0.33 \mu \mathrm{g}$ per gram in aorta tissue (Yakawa and Suzuki-Yasumoto, 1980). Concentrations of vanadium in human blood serum are reported to be 0.016 to 0.939 nanograms per milliliter $(\mathrm{ng} / \mathrm{mL})$. In hair, concentrations of vanadium ranging from 20 to $60 \mathrm{ng}$ per gram have been reported by different authors, with higher values found in manic-depressive patients than in normal control groups (57 versus $29 \mathrm{ng}$ per gram). 


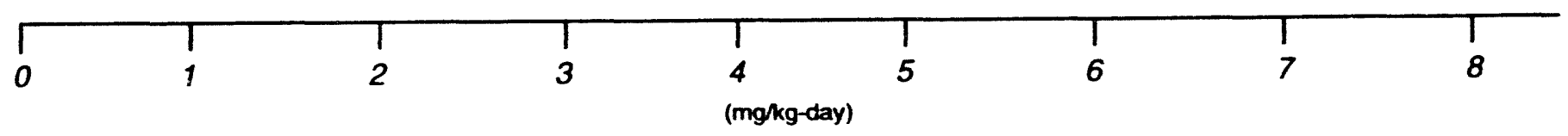

I

DIETARY INTAKE

ORAL REFERENCE DOSE (0.003 $\mathrm{mg} / \mathrm{kg}$-day)

on

REVERSIBLE KIDNEY IMPAIRMENT AFTER ACUTE HUMAN EXPOSURE

(BASED ON DOSE RECONSTRUCTION. CASE STUDY)

- * OBSERVED EFFECTS IN EITHER MICE OR RATS

(SUFFICIENT HUMAN DATA NOT AVAILABLE)

L.:- D

MILD TOXICITY

(RABBITS, RENAL DAMAGE)

FIGURE 5.2

URANIUM TOXICITY RANGES

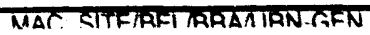


The distribution of vanadium in humans following oral exposure may be extrapolated from animal studies. In acute-duration exposures, vanadium is rapidly distributed, primarily in the bones. After intermediate-duration exposure, vanadium concentrations reaching the tissues are low, with the kidneys, bones, liver, and lungs initially showing the highest levels.

Vanadium is an element and is not metabolized. However, in the body, there is an interconversion of two oxidation states of vanadium: vanadyl and vanadate. Vanadium can reversibly bind to the protein transferrin in the blood and then be taken up into erythrocytes. There is a slower uptake of vanadyl into erythrocytes compared to the vanadate form, possibly due to the time required for the vanadyl form to be oxidized to vanadate. Initially, vanadyl leaves the blood more rapidly than vanadate, possibly because of the slower vanadyl uptake into cells (Harris et al., 1984). Five hours after administration, blood clearance is essentially identical for the two forms. Vanadate is the dominant species of vanadium present in ground water at the Belfield site.

Because vanadium is poorly absorbed in the gastrointestinal tract, a large percentage of vanadium in rats is excreted unabsorbed in the feces following oral exposure. In rats, the principal route of excretion of the small absorbed portion of vanadium is through the kidneys. The mean urinary output per 24 hours is reported to be $10 \mu \mathrm{g}$.

\section{Environmental sources of vanadium}

Elemental vanadium does not occur in nature, but its compounds exist in more than $\mathbf{5 0}$ different mineral ores and in association with fossil fuels. The single largest release of vanadium to the atmosphere occurs through the combustion of fossil fuels, particularly residual fuel oils. The largest amount of vanadium released to soil and water occurs through the natural weathering of geological formations (Byerrum et al., 1974; Van Zinderen Bakker and Jaworski, 1980).

Food constitutes the major source of exposure to vanadium for the general population (Lagerkvist et al., 1986). As a whole, dietary intake is estimated to be 6 to $18 \mu \mathrm{g}$ per day (Pennington and Jones, 1987), although other estimates from older studies using different (and possibly less sensitive) analytical methods have been as high as $2 \mathrm{mg}$ per day (Schroeder et al., 1963).

Drinking water is not considered an important source of vanadium exposure for the general population. Water samples taken from across the United States show 92 percent with values below $10 \mu \mathrm{g} / \mathrm{L}$. Typical values appear to be around $1 \mu \mathrm{g} / \mathrm{L}$ (Lagerkvist et al., 1986). The estimated daily intake of vanadium by inhalation is $1 \mu \mathrm{g}$ (Byrne and Kosta, 1978).

Although vanadium is considered an essential element for chickens and rats, there is no certainty about human dietary requirements. For animals, the daily requirement is about 10 to $25 \mu \mathrm{g}$ per day (Pennington and Jones, 1987). 


\section{Toxicity of vanadium}

The major adverse health effect to humans from vanadium is seen in workers exposed to large amounts of vanadium pentoxide dusts. The probable oral lethal dose of vanadium pentoxide for humans is between 5 and $50 \mathrm{mg} / \mathrm{kg}$ (Gosselin et al., 1976).

Systemic effects of vanadium exposure have been observed in the liver, kidneys, nervous and cardiovascular systems, and blood-forming organs. Metabolic effects include interference with the biosynthesis of cystine and cholesterol, depression and stimulation of phospholipid synthesis, and, at higher concentrations, inhibition of serotonin oxidation. Other effects of vanadium on mammalian metabolism include depression of phospholipid synthesis (Snyder and Cornatzer, 1958), reduction of coenzyme $Q$ levels in mitochondria (Aiyar and Sreenivasan, 1961), and stimulation of monoamine oxidase, which oxidizes serotonin (Perry et al., 1955).

Vanadium salts were given to patients in several studies to reduce cholesterol levels (Curran et al., 1959; Somerville and Davies, 1962; Dimond et al., 1963; Schroeder et al., 1963). The doses of vanadium in these studies varied from 7 to $30 \mathrm{mg}$ per day. Transient decreases in serum cholesterol levels were observed in some patients, as were loosened stool and cramps. Green tongue, a hallmark of vanadium exposure, was observed in all patients.

A relationship between the concentration of vanadium in drinking water and the incidence of dental caries in children is reported by Tank and Storvick (1960). Dental caries incidence in children aged 7 to 11 years was reduced three times (compared to controls) by applying ammonium vanadate in glycerol to the teeth (Belehova, 1969). This relationship was not found in other studies (Hadjimarkos, 1966; 1968).

It has been suggested that raised tissue levels of vanadium are important in the etiology of manic-depressive illness. Improvement after treatment with ascorbic acid or reduced vanadium intake was seen in both manic and depressed patients.

Although animal studies have reported impaired conditioned reflexes following doses of vanadium from 0.05 (6 months) to 0.5 (21 days) $\mathrm{mg} / \mathrm{kg}$-day, effects on the nervous system have not been reported following repeated oral vanadium administration in humans. Workers exposed by inhalation to fairly high concentrations of vanadium compounds (milligrams per cubic meter) have reported nonspecific symptoms, including headache, weakness, vomiting, nausea, and ringing of the ears (WHO, 1988). Available data on vanadium toxicity are insufficient to evaluate effects on cholesterol levels, iron metabolism, blood cell production, and mutagenesis. However, due to poor absorption from the gut, the metal is not considered very toxic following oral administration (WHO, 1988). The toxicity of vanadium is summarized in Figure 5.3. 


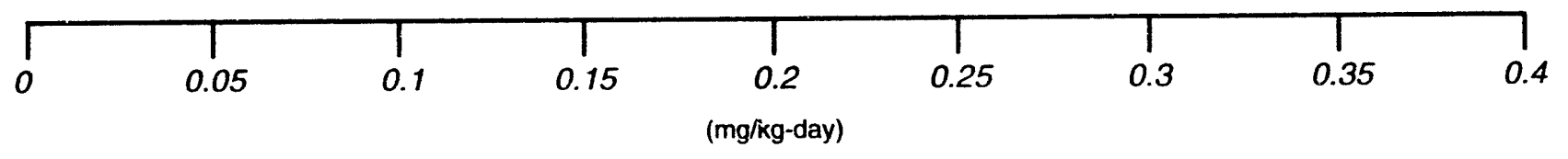

| DIETARY INTAKE

A ORAL REFERENCE DOSE (HEAST) - DRINKING WATER $(0.007 \mathrm{mg} / \mathrm{kg}$-day)

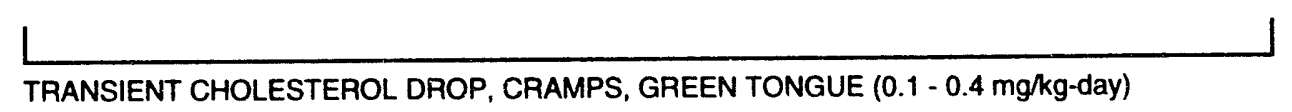

ESTIMATED LETHAL DOSE (5 - $50 \mathrm{mg} / \mathrm{kg}$-day)

FIGURE 5.3

VANADIUM TOXICITY RANGES 


\subsection{CONTAMINANT INTERACTIONS}

Some information is available on potential interactions between contaminants found at UMTRA Project sites. However, discussions of potential interactions can generally be presented only qualitatively. In addition to physiological variables among individuals that can affect toxicity, uncertainties in interactions also result from 1) differences in the relative exposure concentrations of the different contaminants compared to the concentrations tested experimentally, and 2) the presence of additional ground water constituents that may be present in sufficient quantities to modify predicted toxicities, even though they themselves are not considered contaminants of potential concern for human health. Therefore, the interactions described below should be recognized as factors that can influence the predicted toxicity, although the precise nature and magnitude of that influence cannot be determined.

A primary concern at UMTRA Project sites is the potential for interactions between metals. Interactions between several similar metals can alter the predicted absorption, distribution in the body, metabolism, toxicity, or clearance of a metal of interest. At the Belfield site, there is the potential for interaction of not only metals attributable to site activities but also metals naturally occurring in background ground water. Metal constituents occurring in background ground water at levels of concern for chemical interactions would include those constituents above the available health advisory levels and/or EPA MCLs. The maximum background concentrations of antimony, boron, cadmium, chromium, lead, molybdenum, selenium, and sulfate exceed the available health advisory levels and/or EPA MCLs.

Potential interactions involving site contaminants would not significantly affect their toxicity overall. Oral administration of vanadium may interfere with copper metabolism by inhibiting the intestinal absorption of copper, leading to copper deficiency (DHHS, 1992). Copper is present in ground water above background concentrations but not above recommended nutritional levels. The presence of additional copper may offset any loss of copper absorption due to the presence of vanadium. No information on interactions of uranium with other metals has been found. However, uranium-produced kidney damage would impair excretion of magnesium and other metals, and high levels of these metals could lead to the manifestation of their toxicity. Potential kidney impairment may be magnified given the levels of cadmium present in the site vicinity and the potential for cadmium toxicity to be additive based on the common target organ.

Potential interactions involving constituents above health advisories or MCLs in background ground water would likely affect their individual toxicity.

Sulfate interacts in a complex manner with molybdenum and copper. Ruminants seern to be the most susceptible species to imbalances between these elements. In ruminants, copper prevents the accumulation of molybdenum in the liver and may antagonize absorption of molybdenum. Molybdenum can produce a functional copper deficiency, but only in the 
presence of sulfate. It has also been suggested that sulfur can displace molybdate in the body (Casarett and Doull, 1991). In laboratory animal studies, the toxicity of molybdenum is more pronounced in situations where dietary copper intake is low (EPA, 1993). In ruminants, both copper and sulfates can protect against molybdenum toxicity, and molybdenum and sulfur can block copper toxicity.

Molybdenum in the form of sodium molybdate has alleviated cadmium toxicity in rats. The absorption of cadmium can be considerably increased under conditions of low intake of calcium, iron, or protein (Nordberg et al., 1985). Low body iron stores can increase cadmium uptake four-fold (Flanagan et al., 1978).

Cadmium, copper, manganese, and zinc can induce synthesis of the metalbinding protein metallothionein (DHHS, 1993, 1992; Casarett and Doull, 1991). This protein seems to have a paradoxical effect on the systemic toxicity of cadmium. Metallothionein binds cadmium and in this way protects certain organs such as the testes from cadmium toxicity. However, the methallothionein-cadmium complex may enhance nephrotoxicity, since the complex is taken up by the kidney more readily than the free ion. However, in the continued presence of these other metals, there may be competition for metallothionein binding sites.

Selenium interacts with a wide range of metals, including arsenic, bismuth, cadmium, cobalt, copper, lead, mercury, platinum, silver, tellurium, and thallium (Friberg et al., 1986). Selenium forms insoluble complexes with silver, copper, cadmium, and mercury. Selenium deficiency may develop in the presence of these other metals, as is seen with cobalt and copper. The formation of these complexes can reduce the toxicity of both selenium and the other metals (Casarett and Doull, 1991). Most of these interactions have been observed in laboratory animals or in livestock. The mechanisms are not completely understood in many cases. Often the selenium-metal complex binds in a stable complex to a larger protein than the metal alone, and a redistribution of this complex away from target tissues occurs.

Selenium can protect against most acute effects of cadmium in rats, but it does not protect against chronic kidney toxicity. Sulfate can also interact with selenium, but the interaction is inconsistent. Sulfate at high doses can reduce some toxic effects of selenium, but not others (such as liver damage) (DHHS, 1989).

\subsection{CONTAMINANT RISK FACTORS}

The EPA Office of Research and Development has calculated acceptable intake values, or reference doses (RfD), for long-term (chronic) exposure to noncarcinogens. These values are estimates of route-specific exposure levels not expected to cause adverse effects when exposure occurs for a significant portion of a lifetime. The RfDs include safety factors to account for 
uncertainties associated with limitations of the toxicological data base, including extrapolating animal studies to humans and accounting for variability in response from sensitive individuals. These values are updated quarterly and published in the Health Effects Assessment Summary Tables (HEAST) (EPA, 1992); they are also provided through the EPA'S IRIS data base. Table 5.1 summarizes the most recent oral RfDs for the noncarcinogenic contaminants of potential concern and those constituents in background ground water at levels exceeding the acceptable intake value.

The EPA currently classifies all radionuclides as Group A, or known human carcinogens, based on their property of emitting ionizing radiation and on the evidence provided by epidemiological studies of radiation-induced cancer in humans. Risk factors are published in HEAST and IRIS for correlating intake of carcinogens over a lifetime with the increased excess cancer risk from that exposure. Table 5.2 gives the most recent cancer slope factors (SF) for the uranium-234/-238 radioactive decay series.

Table 5.1 Toxicity values: potential noncarcinogenic effects

\begin{tabular}{|c|c|c|c|c|c|}
\hline Chemical & $\begin{array}{c}\text { Chronic } \\
\text { oral RfD } \\
\text { (mg/kg-day) } \\
\end{array}$ & $\begin{array}{c}\begin{array}{c}\text { Confidence } \\
\text { level }\end{array} \\
\end{array}$ & $\begin{array}{c}\text { Critical } \\
\text { effect/organ }\end{array}$ & $\begin{array}{l}\text { RfD basis/ } \\
\text { RfD source }\end{array}$ & $\begin{array}{c}\text { Uncertainty } \\
\text { factor }\end{array}$ \\
\hline Antimony & $4 E-04$ & Low & $\begin{array}{l}\text { Increased } \\
\text { mortality/altered } \\
\text { blood chemistries }\end{array}$ & Water/HEAST & 1000 \\
\hline Boron & $9 E-02$ & NA & Lesions/testes & Diet/HEAST & 100 \\
\hline Cadmium & $5 E-04$ & High & Kidney & Water/HEAST & 10 \\
\hline Chromium (III) & 1.0 & NA & None observed & Diet/HEAST & 1000 \\
\hline Lead & NA & NA & $\begin{array}{l}\text { Central nervous } \\
\text { system effects }\end{array}$ & NA & NA \\
\hline Molybdenum & $5 E-03$ & High & Bone & Water/HEAST & 2 \\
\hline Selenium & $5 \mathrm{E}-03$ & High & Hair, nails, skin & Diet/IRIS & 15 \\
\hline Sulfate & NA & High & Diarrhea & Water/NA & 1 \\
\hline Uranium & $3 E-03$ & Medium & $\begin{array}{l}\text { Kidney, decreased } \\
\text { body weight }\end{array}$ & Water/IRIS & $100-1000$ \\
\hline Vanadium & 7E-03 & Low & Hair & Water/HEAST & 100 \\
\hline
\end{tabular}

NA - not available. 
Table 5.2 Toxicity values: potential carcinogenic effects

\begin{tabular}{lcccc}
\hline \multicolumn{1}{c}{ Parameter } & $\begin{array}{c}\text { Oral SF } \\
(\mathrm{pCi})^{-1}\end{array}$ & $\begin{array}{c}\text { Weight of } \\
\text { evidence } \\
\text { classification }\end{array}$ & Type of cancer & SF basis/SF source \\
\hline Lead-210 & $5.1 \mathrm{E}-10$ & $\mathrm{~A}$ & Bone & Water/HEAST \\
Polonium-210 & $1.5 \mathrm{E}-10$ & $\mathrm{~A}$ & Liver, kidneys, spleen & Water/HEAST \\
Radium-226 & $1.2 \mathrm{E}-10$ & $\mathrm{~A}$ & Bone & Water/HEAST \\
Thorium-230 & $1.3 \mathrm{E}-11$ & $\mathrm{~A}$ & Bone & Water/HEAST \\
Uranium-238 & $1.6 \mathrm{E}-11$ & $\mathrm{~A}$ & Note $^{\mathrm{a}}$ & Water/HEAST \\
Uranium-234 & $1.6 \mathrm{E}-11$ & $\mathrm{~A}$ & Note $^{\mathrm{a}}$ & Water/HEAST \\
\hline
\end{tabular}

Note: No human or animal studies have shown a definite association between oral exposure to natural uranium and development of cancer. 


\subsection{RISK EVALUATION}

To evaluate human health risks to an individual or population, the results of the exposure assessment are combined with the results of the toxicity assessment. As discussed in Section 5.0, potential adverse health effects are a function of how much of a contaminant an individual takes in. At lower levels, some contaminants are beneficial to health, since they are essential nutrients. At higher levels, these same elemerits can cause adverse health effects or even death. In this section, the expected intake of contaminants of potential concern, if contaminated ground water were used as drinking water, is correlated to potential health effects from these levels of exposure.

This risk evaluation is based on levels of the contaminants of potential concern observed in the upper zone as a result of the ashing process. Based on a review of the data, it was determined that the potential risks from exposure to ground water in the lignite zone would be less than those for the upper zone and therefore were not evaluated further. Risks would be expected from levels of constituents in background ground water. However, risk from naturally occurring constituents was not quantified; rather, only the incremental risks potentially resulting from processing site activities are addressed. This incremental risk is substantially less than the potential risks associated with ingestion of background ground water in the site vicinity.

\subsection{POTENTIAL NONCARCINOGENIC HEALTH EFFECTS}

The results from the exposure assessment showing either the highest intake-tobody-weight ratios (i.e., highest doses) or the toxicologically most sensitive group are used to evaluate potential health effects for noncarcinogens. For the two metal constituents attributable to the Belfield site, uranium and vanadium, the highest intake-per-body-weight group is children 1 to 10 years old.

Uranium and vanadium are addressed as the primary concern for potential site-related human health impacts from ingestion of contaminated ground water in the upper zone at the Belfield site. For vanadium, more than 99 percent of the exposure distribution falls below the EPA-derived oral RfD and well below any adverse health effect level (Figure 6.1).

Ninety-nine percent of the exposure distribution for uranium is two orders of magnitude below the lowest exposure level resulting in an adverse health effect, and falls entirely within the no-observed-effect level. However, about 50 percent of the exposure distribution falls above the EPA acceptable intake level (RfD of $0.003 \mathrm{mg} / \mathrm{kg}$-day) (Figure 6.2). This discrepancy occurs largely because the toxicological data base is incomplete, and the EPA has taken this significant uncertainty into account in establishing its oral RfD for acceptable intake. Uranium has not been demonstrated to serve a beneficial purpose in biological systems; therefore, unlike nutrient metals, it is difficult to define a threshold of toxicity. The estimated intakes of uranium have not been associated with adverse effects in humans or test animals. However, it is 


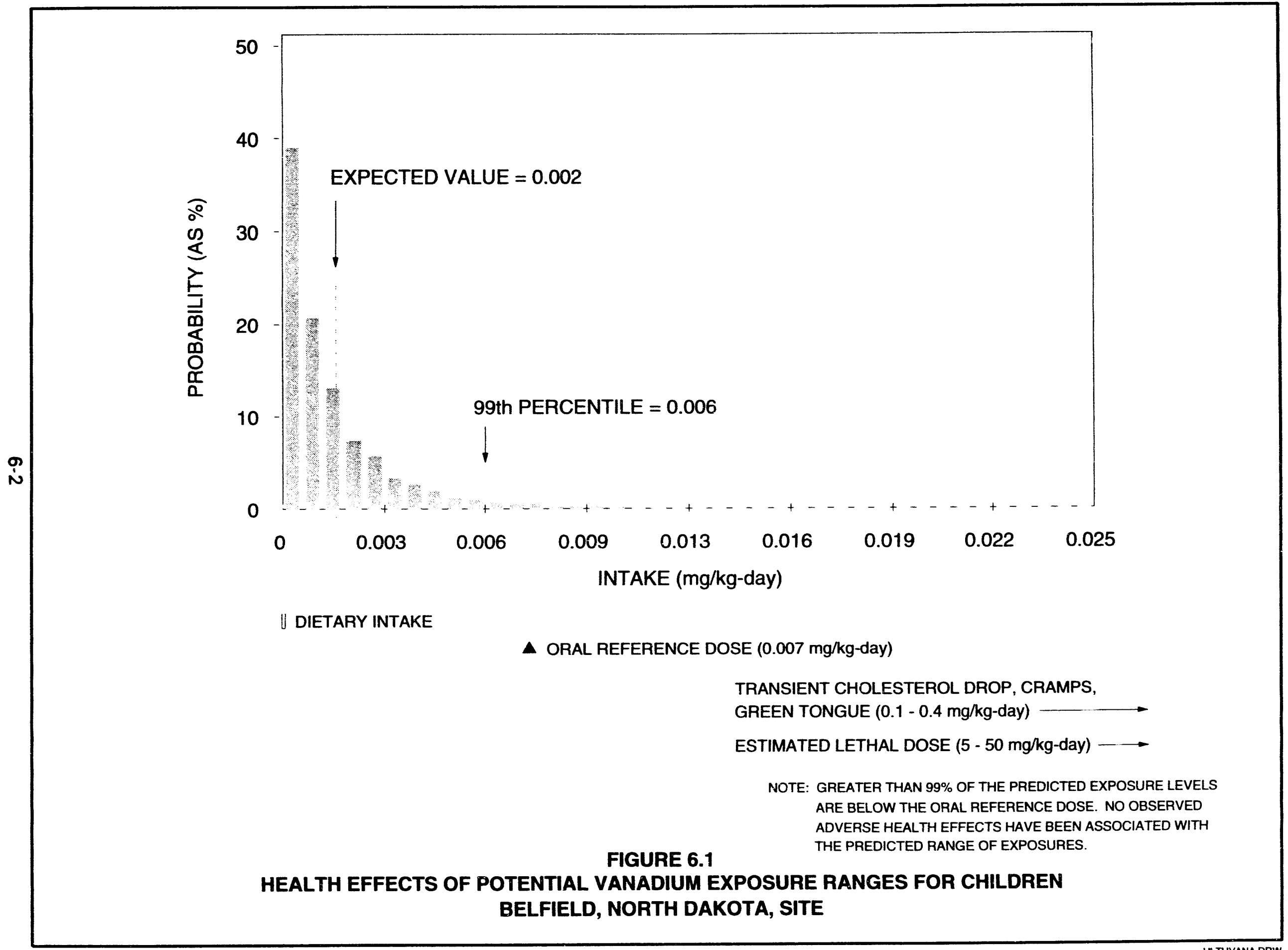




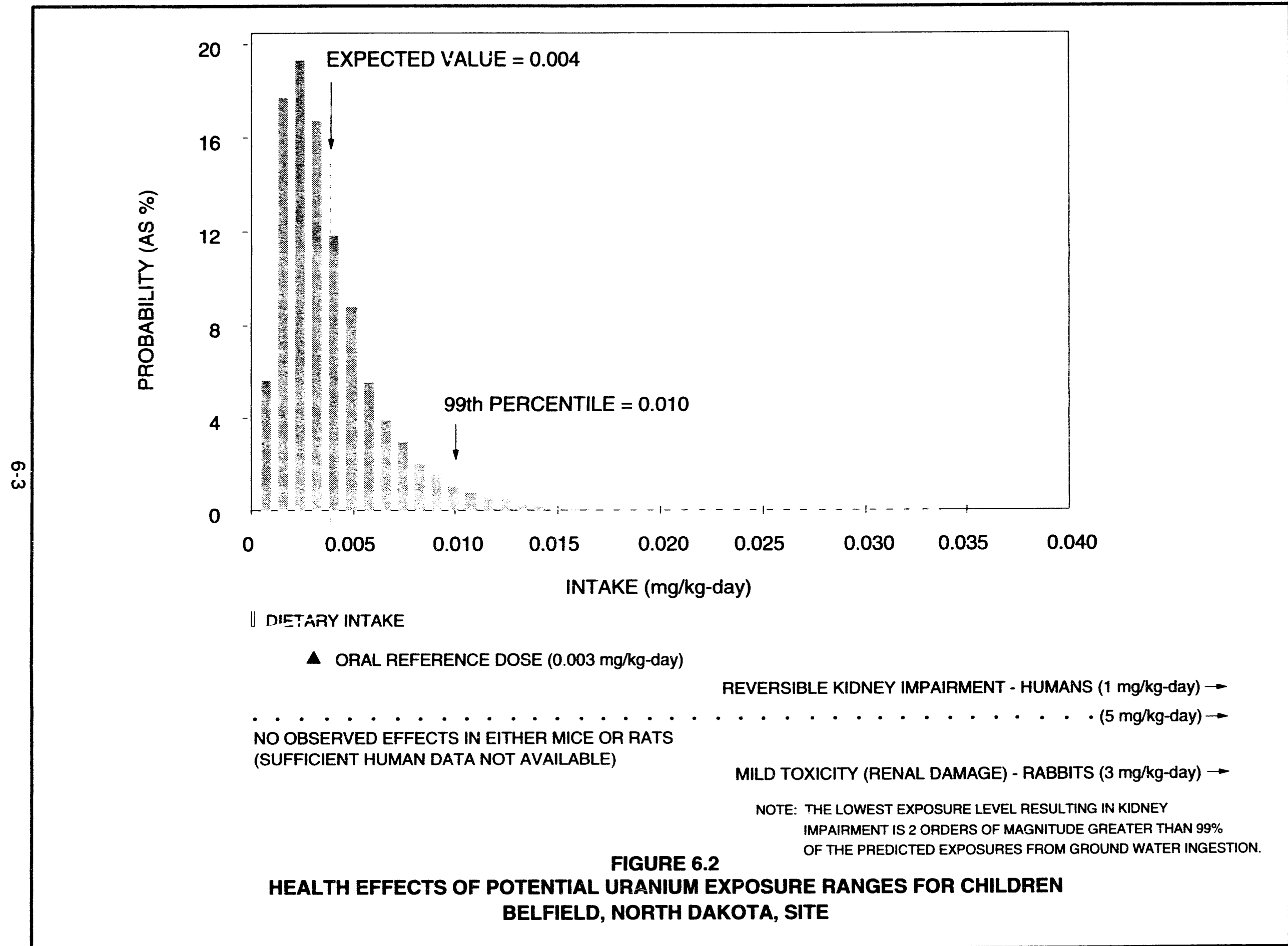


significant that half of the exposure distribution falls above this RfD criterion due to the low level of confidence in the toxicological data.

\subsection{POTENTIAL CARCINOGENIC HEALTH EFFECTS}

Ali uranium isotopes are radioactive and, as such, are considered potential carcinogens. Natural uranium, however, has not been demonstrated to cause cancer in humans or animals following ingestion exposures. For ingestion of ground water at the Belfield site, the estimated carcinogenic risk for the uranium-234/-238 radioactive decay series are based on the cancer SFs developed by the EPA (Table 5.2).

Uranium is the only radionuclide consistently measured above background levels in the area of well 520. However, since uranium decays to radioactive progeny, the longer-lived radioactive progeny of the uranium decay series were evaluated for carcinogenic risk. Thorium-230, polonium-210, radium-226, and lead-210 have been detected consistently on and in the vicinity of the site, although not at levels statistically above background levels. The total excess cancer risk is conservatively based on the maximum concentrations in plume well 520 . The risks associated with uranium and its radioactive longer-lived progeny are within the EPA acceptable range, which according to the National Contingency Plan is between 1 in 10,000 to 1 in $1,000,000\left(10^{-4}\right.$ and $\left.10^{-6}\right)$ excess cancers (Table 6.1).

Table 6.1 Excess lifetime cancer risk calculations for ground water ingestion by a hypothetical future adult resident, Belfield UMTRA Project site, Belfield, North Dakota

\begin{tabular}{|c|c|c|c|c|c|}
\hline Radionuclide & $\begin{array}{c}\text { Exposure point } \\
\text { concentration } \\
\text { (pCi/L) }\end{array}$ & $\begin{array}{c}\text { Well } \\
\text { location }\end{array}$ & $\begin{array}{c}\text { Intake } \\
\text { (pCi/lifetime) }\end{array}$ & $\begin{array}{l}\text { Ingestion SF } \\
(\mathrm{pCi})^{-1}\end{array}$ & $\begin{array}{c}\text { Excess } \\
\text { lifetime } \\
\text { cancer } \\
\text { risk }^{b}\end{array}$ \\
\hline Uranium $^{c}$ & 73 & 520 & $2,555,000$ & $1.6 E-11$ & 4.1E-05 \\
\hline Lead-210 & 2.8 & 520 & 98,000 & $5.1 E-10$ & $4.9 \mathrm{E}-06$ \\
\hline Polonium-230 & 1.4 & 520 & 49,000 & $1.5 \mathrm{E}-10$ & $7.4 \mathrm{E}-06$ \\
\hline Thorium-230 & 0.4 & 520 & 14,000 & $1.3 E-11$ & $1.8 \mathrm{E}-07$ \\
\hline \multirow[t]{2}{*}{ Radium-226 } & 0.5 & 520 & 17,500 & $1.2 E-10$ & 2.1E-06 \\
\hline & & & & Total: & 5.6E-05 \\
\hline
\end{tabular}

a Maximum detected concentration.

b Intake $\times$ slope factor $=$ excess lifetime cancer risk.

CUranium-234 and uranium-238 combined. The oral SF is the same for both isotopes. 


\subsection{LIMITATIONS OF RISK EVALUATION}

The following potential limitations apply to interpretations of this risk evaluation:

- This risk assessment evaluates only risks related to inorganic ground water contamination. The presence of organics was not investigated.

- This risk evaluation is based on exposure to incremental levels of inorganic constituents attributable to the processing activities. It does not take into account the potential baseline risk from exposure to naturally occurring constituents present in background ground water that are above health advisory levels and/or EPA MCLs.

- Subpopulations that might have increased sensitivity, such as the elderly or individuals with preexisting disease, are not specifically addressed in the toxicity ranges presented on the graphs.

- Some individuals may be more sensitive to the toxic effects of certain constituents for undetermined reasons.

- Data available to interpret potential adverse health effects may not always be sufficient to allow accurate determination of all health effects due to lack of human data or testing of dose ranges other than those expected at this site.

- Although plume movement is evaluated hydrologically and geochemically, the monitoring locations sampled may not have tapped into the most contaminated portion of the plume. Additionally, concentrations may increase or decrease as conditions change.

- Only the drinking water exposure pathway has been considered in depth, although other pathways were screened to determine their contribution.

The evaluation presented here has considered these limitations and compensated wherever possible by presenting toxicity ranges and probabilistic exposure assessments rather than point estimates to incorporate as much variability as could be reasonably defined. The impact of these potential limitations is discussed more fully in Section 8.2. 


\subsection{LIVESTOCK AND ENVIRONMENTAL EVALUATION}

The objective of the environmental portion of the risk assessment is to determine whether contaminants detected at the site have the potential to adversely affect the existing biological community at or surrounding the site. Currently, the EPA has no guidance for quantifying potential impacts to ecological receptors but has developed a qualitative approach generally used for ecological evaluations (EPA, 1989b). With the qualitative approach, the EPA recommends comparing ambient environmental media concentrations with water quality, sediment quality, or other relevant criteria to determine whether any of the concentrations that the ecological receptors are expected to encounter exceed these criteria.

The effects of contaminants on individual ecological receptors are a concern; however, it is difficult to predict whether observed effects on individual populations will damage the ecosystem. Populations are dynamic; therefore, information concerning the normal range of variability within the population needs to be known. Sublethal effects, which may be very important to overall ecosystem health, are difficult to detect, and contaminants at low concentrations may not kill organisms directly but may diminish their ability to survive and reproduce. No studies to determine sublethal effects were conducted as part of this evaluation.

\subsection{EXPOSURE CHARACTERIZATION}

This section identifies the possible exposure pathways to ecological receptors. For risk to exist, a receptor must be exposed to contaminants. Exposure can occur only if there is both a source of contamination and a mechanism of transport to a receptor population or individual.

Both current and potential future exposure were considered for the potentially impacted media at the site, which include soil, surface water, sediments, and ground water. For ecological receptors at the site, there is a future potential exposure pathway to contaminated ground water through a hypothetical ground water-fed pond and irrigation. There is a current exposure pathway to surface water and sediments. Ground water is not considered hydraulically connected to surface water (Section 2.3.2); therefore, there is no current exposure pathway to ground water. However, surface water was evaluated for potential contamination from wind or soil erosion of surface contamination.

Exposure to surface water and sediments is based on a qualitative evaluation of all available surface water and sediment data. The future exposure pathway to ground water assumes the maximum concentration of the contaminants of potential concern identified in Section 3.0.

In addition to direct exposure pathways, indirect exposure pathways, such as consumption of previously exposed organisms or plants, are addressed in this environmental evaluation. 
It is unlikely that plants are taking up contaminants directly from the ground water through their roots. Depth to ground water in the vicinity of the site is approximately $30 \mathrm{ft}(9 \mathrm{~m})$. Uptake from plants irrigated with contaminated ground water is considered a future potential exposure pathway.

The use of contaminated ground water for watering livestock is also a future potential exposure pathway likely to occur in the site vicinity. For this pathway and the irrigation pathway, a conservative approach was assumed for a domestic well that could, in the future, intercept the most contaminated ground water at the site. Water from this hypothetical well could be used for livestock watering and small-scale irrigation. The use of shallow ground water for commercial irrigation is not likely due to the low yield of the upper zone.

\subsection{ECOLOGICAL RECEPTORS}

This section identifies ecological resources at the site and in its vicinity that are potentially exposed to site-related contaminants. The following information on ecological receptors is based on several field surveys conducted in the area between 1986 and 1993.

Limited observational data on te:restrial flora and fauna were collected during a July 1992 field survey. During a 1993 ecological site visit, surface water and sediment samples were collected from the area. No quantitative information on aquatic organisms is available. However, none have been observed and, considering the lack of continuous water in the Heart River in the site vicinity, the presence of aquatic organisms is probably minimal.

Because of the nature of the ashing process and subsequent uses of the property, the land inside the designated site boundary has been physically disturbed. Nonnative grasses predominate within the site boundary. Outside the site boundary, three vegetative community types have been identified.

\subsubsection{Flora}

The Belfield site is in the Upper Missouri Basin and Broken Land physiographic region within the shortgrass-wheatgrass-needlegrass plant association (Kuchler, 1975). Two grass-dominated types and one wooded community type were identified at the Belfield site (Figure 7.1). The first plant community type is dominated by nonnative grass species along the easement between the Burlington Northern Railroad and a county road just south of the railroad. This area is dominated by smooth brome along with a variety of herbaceous plants (DOE, 1993). The second plant community type is grass-dominated pasture and occurs adjacent to woody vegetation along the Heart River. This area is actively grazed and has a plant species composition similar to the nonnative grassland plant community; crested wheatgrass is also common along with smooth brome (DOE, 1993). 


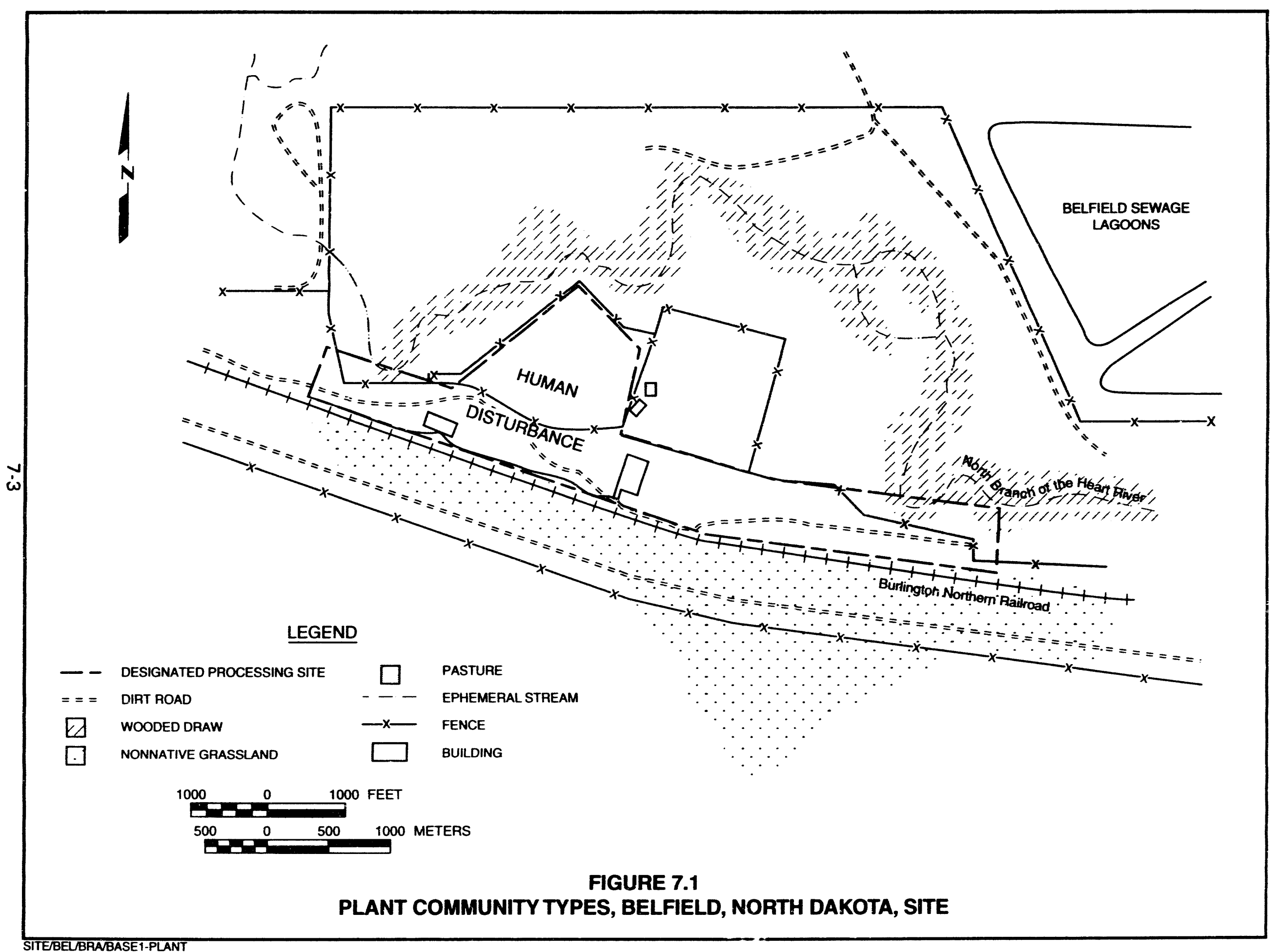


The third plant community type is a wooded draw that occurs along the North Branch of the Heart River - the Fraxinus pennsy/vania/Ulmus americana/Prunus virginianus type (Girard et al., 1984). The vegetation in the wooded draw consists of deciduous trees and shrubs that grow in a narrow band along the river. The dominant tree species are American elm and green ash. Chokecherry is an abundant tall shrub in the understory, while the most abundant common low-growing shrub is snowberry. The ground cover is dominated by grass; various herbaceous plant species also were observed. Emergent aquatic vegetation grows in narrow bands along the river; various species of rushes, sedges, bulrushes, and arrowhead were commonly observed. This wooded draw is a designated wetlands area (Disbro, 1986; Zschomier, 1986) and is also designated as unique habitat in North Dakota by the U.S. Fish and Wildlife Service (FWS) (Collins, 1987). This area is actively grazed by cattle and the ground cover is relatively short in most areas. A decline in the health and abundance of the tree population along the river has been observed during site visits over the past 5 years. In 1986, heavy insect infestation defoliated a great percentage of the trees along the river. In addition, some large trees have died off with little reproduction, presumably because of grazing. These woods appear to be in a state of decline, as has been observed in other hardwood draws in southwestern North Dakota (DOE, 1992).

\subsubsection{Fauna}

Detailed studies of reptiles and amphibians in the vicinity of the Belfield site have not been conducted.

Thirty-six species of breeding birds were observed in the wooded draw. A total of 51 species of birds were observed during surveys at the site (TAC, 1992, 1987, 1986).

Detailed field studies of wild mammals were not conducted; however, a total of 32 species of wild mammals may occur in the Belfield site area (TAC, 1992).

\section{Threatened or endangered species and other species of concern}

The potential occurrence of threatened and endangered (T\&E) species and other species of concern at the Belfield site was determined by consulting with the FWS and the North Dakota Game and Fish Department. The state indicated that no state-listed plant or animal species occur near the site (Henegar, 1985). Informal consultation with the FWS occurred in 1986, 1989, and 1992 (Bowman, 1986; Sapa, 1992, 1989). Four endangered species were determined to have the potential to occur at the site (the bald eagle, peregrine falcon, whooping crane, and black-footed ferret). However, further investigations concluded that permanent residency by any of these species is unlikely because of specific habitat needs lacking at the Belfield site. Consultation with the FWS indicated that five candidate species may occur near the site (regal frittillary butterfly, loggerheaded shrike, swift fox, ferruginous 

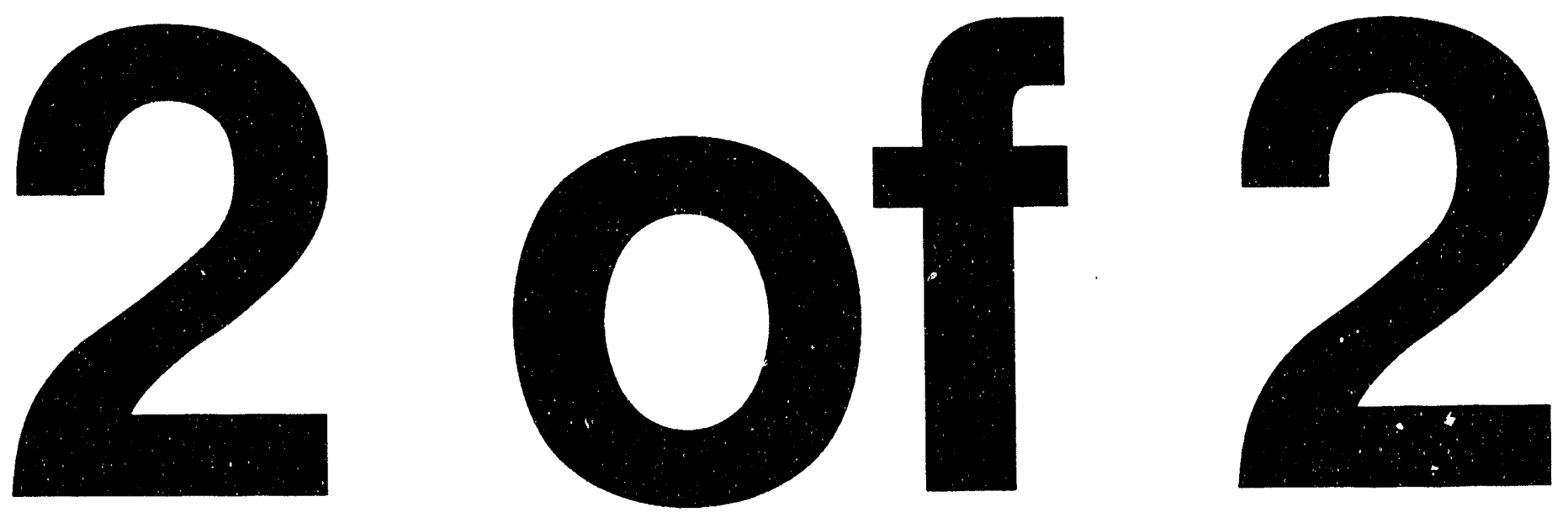
hawk, and long-billed curlew). None of these species were observed during specific T\&E surveys at the Belfield site (DOE, 1992).

\subsubsection{Aquatic organisms}

Because of the ephemeral nature of the Heart River, fish and macroinvertebrates have not been observed. Microinvertebrates were not surveyed. The often dry conditions of most of the river reach near the Belfield site would limit the occurrence of these organisms.

\subsection{CONTAMINANTS OF POTENTIAL ECOLOGICAL CONCERN}

The list of ground water constituents found to be above background levels was used as the list of contaminants of potential concern for ecological receptors (Table 3.4, column 1) exposed to ground water. Exposure to the maximum ground water concentrations of aluminum, barium, calcium, chloride, copper, magnesium, silver, strontium, uranium, and vanadium was evaluated.

A review of the surface water data showed no evidence of impacts from ground water, which supports the previous hydrogeologic determination that ground water does not hydraulically influence surface water in the site vicinity (Section 2.3.2). Therefore, assessment of risk from direct exposure to surface water and sediments is based on available surface water and sediment quality data (summarized in Table 3.6). The assessment of risk from indirect exposure to ground water is based on filtered ground water data.

Available unfiltered surface water and ground water quality data did not indicate any limitations to the use of filtered data, although the size of the data set limits its conclusiveness. Therefore, filtered water quality data were used in the assessment. One round of sediment samples was collected and analyzed for selenium, molybdenum, chromium, and uranium only.

\subsection{POTENTIAL IMPACTS TO WILDLIFE AND PLANTS}

Future potential exposure of biota to maximum concentrations of contaminants of potential concern for ground water is assumed; current exposure to surface water is represented by the maximum concentrations for available surface water quality data. Exposure to levels of metal constituents found naturally in background ground water was not evaluated.

\subsubsection{Future risk from ground water}

Terrestrial vegetation can be exposed to contaminanis in ground water through root uptake. Contaminants may bioaccumulate in various plant parts and exert a wide range of influences, depending on the specific contaminant. Plant uptake rates vary greatly among species and are affected by factors such as soil characteristics $(\mathrm{pH}$, moisture, redox potential, and organic matter), plant 
sensitivity, input-output balance, and cumulative effects. Although it is not likely that plants have rooting zones in soils intercepting contaminated ground water at the Belfield site, plants could be irrigated with contaminated ground water and could be similarly affected. This is considered for a small irrigated field or garden scenario.

Concentrations of the contaminants of potential concern in plant tissue at harvestable maturity were estimated using soil-to-plant bioconcentration factors (BCF). No soil data or water-to-plant BCFs are available for the site. Soil concentrations in the saturated zone were estimated by multiplying the ground water concentration by the soil-water distribution coefficient, Kd. Some information is available, for comparison, on tissue accumulation levels that would be toxic in plants (Kabata-Pendias and Pendias, 1992). Table 7.1 presents the parameters used to estimate root uptake and plant tissue concentrations. This methodology is described in detail in the literature (Baes et al., 1984) and will not be presented here.

The estimated tissue concentrations for constituents in vegetative portions (e.g., stems and leaves) and in nonvegetative portions (e.g., fruits and tubers) were compared with approximate concentrations (in mature leaf tissue) reported to be toxic to plants (phytotoxic). Few available data relate tissue concentrations to phytotoxicity. Those phytotoxic concentrations reported are not representative of very sensitive or highly tolerant plant species.

Plant tissue concentrations for vanadium, copper, and silver would not exceed phytotoxic levels. Phytotoxicity data were unavailable for calcium, strontium, aluminum, uranium, chloride, and magnesium. The observed levels of calcium, aluminum, and magnesium are not likely to cause adverse irnpacts to plants through irrigation water. Overall, this assessment is inconclusive without more information on such things as the soil environment.

The net accumulation by organisms of a constituent directly from the surrounding environment is known as bioconcentration. Generally, bioconcentration is measured for uptake of chemicals from water by aquatic organisms. Freshwater fish BCFs exist in the scientific literature for a limited number of constituents. However, fish are not present in the Heart River in the site vicinity. Therefore, bioconcentration of contaminants by fish is not part of this evaluation.

Net accumulation by organisms as a result of all routes of exposure, including the diet, is known as bioaccumulation. Bioaccumulation in terrestrial organisms is a function of the levels of contaminants ingested through other plants or animals. Foraging wildlife can be exposed indirectly to contaminants in ground water by ingesting plants that may have bioaccumulated certain contaminants. In the case of small contaminated areas, the amount of food in the diet usually exceeds the affected food, and bioaccumulation is not a concern. Therefore, the potential for bioaccumulation is not always a concern. 


\begin{tabular}{|c|c|c|c|c|c|c|c|c|c|}
\hline \multirow{11}{*}{ 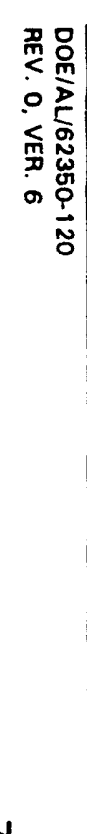 } & \multirow[b]{2}{*}{$\begin{array}{l}\text { Conteminent } \\
\text { boove } \\
\text { beckground } \\
\text { levels in } \\
\text { ground water }\end{array}$} & \multicolumn{8}{|c|}{$\begin{array}{l}\text { mparison of estimated plant concentrations to phytotoxic concentrations, Belfield UMTRA Project site, } \\
\text { field, Norta. Dakota }\end{array}$} \\
\hline & & $\begin{array}{l}\text { Maximum } \\
\text { concentration } \\
\text { in ground } \\
\text { water } \\
\text { (mg/L) }\end{array}$ & Kd (L/kg) & $\begin{array}{l}\text { Estimated soil } \\
\text { concentration } \\
\text { (mg/kg DW) }\end{array}$ & $\begin{array}{l}\text { Soil- } \\
\text { concentr } \\
\text { Bv }\end{array}$ & $\frac{\text { to-plant }}{\text { ation factors }}$ & $\begin{array}{c}\text { Estimated } \\
\text { concentration } \\
\text { in vegetative } \\
\text { growth" } \\
\text { (mg/kg DW) } \\
\end{array}$ & $\begin{array}{c}\text { Estimated } \\
\text { concentration } \\
\text { in } \\
\text { fruits/tubers } \\
\text { (mg/kg DW) }\end{array}$ & $\begin{array}{c}\text { Approximate } \\
\text { concentration } \\
\text { in mature leaf } \\
\text { tissue that is } \\
\text { toxic } \\
\text { (mg/kg DW) }\end{array}$ \\
\hline & Calcium & 630 & 4 & 2520 & 3.5 & 0.35 & 8820 & 882 & NA \\
\hline & Strontium & 3.5 & 100 & 350 & 2.5 & .5 & 875 & 87.5 & NA \\
\hline & Uranium & 0.106 & 50 & 270 & 0.0085 & $u .004$ & 2.29 & 1.08 & NA \\
\hline & Aluminum & 0.31 & 35000 & 10940 & 0.004 & 0.0006 & 44 & 7 & NA \\
\hline & Barium & 0.10 & 2800 & 280 & 4.0 & 2.0 & 1120 & 560 & $50-20$ \\
\hline & Chloride & 755 & NA & - & 70 & 70 & - & - & NA \\
\hline & Copper & 0.05 & 92 & 4.61 & 0.40 & 0.25 & 2 & 1 & $20-100$ \\
\hline & Magnesium & 298 & 1400 & 417000 & 1.0 & 0.55 & 417000 & 229500 & NA \\
\hline & Silver & 0.03 & 4 & 0.12 & 0.40 & 0.10 & 0.05 & 0.01 & $5-10$ \\
\hline & Vanadium & 0.100 & 100 & 10 & 0.0055 & 0.003 & 0.055 & 0.03 & $5-10$ \\
\hline
\end{tabular}

${ }^{8}$ Estimated concentration in vegetative portions, calculated as estimated soil concentration multiplied by Bv.

Estimated concentration in nonvegetative portions, calculated as estimated soil concentration multiplied by $\mathrm{Br}$.

${ }^{c}$ Concentrations are not presented for very sensitive or for highly tolerant plant species (Kabata-Pendias and Pendias, 1992).

Kd - soil-water distribution coefficient; from PNL, 1989, except for calcium. No Kd for calcium is available in PNL, 1989; Kd shown is from Baes et al. (1984).

Bv - soil-to-plant elemental transfer factor for vegetative portions of food crops and feed plants (Baes et al., 1984).

$\mathrm{Br}$ - soil-to-plant elemental transfer factor for nonvegetative portions (e.g., fruits, tubers), of food crops and feed plants (Baes et al., 1984).

DW - dry weight.

NA - not available.

Note: There are few available data for phytotoxicity. 
Biomagnification is a more severe situation in which the concentration of a constituent increases in higher levels of the food chain because the contaminant concentratior.s are accumulated through each successive trophic level. Only a limited number of constituents are known to magnify in the food chain. Based on available information, the potential for the detected contaminants at the site to represent a concern via food chain transfer is low. Thus, the constituent concentration does not increase up the food chain.

The maximum concentrations for the contaminants of potential concern for ground water were compared to available surface water quality criteria to evaluate potential impacts to livestock from drinking contaminated ground water (i.e., livestock and wildlife drinking from a ground water-fed pond or fish stocked in the pond) (Table 7.2). No federal or state criteria or standards are established to protect terrestrial wildlife via water exposure. There are a limited number of water quality criteria for aquatic organisms and for livestock. The comparison of on-site conditions to these criteria provides some insight into potential risk to terrestrial and aquatic receptors. However, without additional information, accurate site-specific risks cannot be identified.

Aluminum and copper concentrations are well below criteria for the protection of livestock and biota (e.g., aquatic organisms, wildlife), as shown in Table 7.2. Vanadium is at the acceptable level. No water quality criteria are available for barium, calcium, chloride, magnesium, silver, strontium, and uranium. Calcium and magnesium would not be considered a concern for toxicity to biota at the levels observed. The potential for impacts from strontium or silver are difficult to assess without additional information; however, levels are within those observed naturally in water in several parts of the country, including North Dakota.

\subsubsection{Current risk from surface water}

\section{Heart River water}

A comparison of water quality upstream of the site to water quality adjacent to the site in the North Branch of the Heart River shows that levels nearer the site do not tend to be higher than levels upstream (Table 3.6). Variability in surface water quality all along the Heart River in the site vicinity can be expected naturally because of sample turbidity, seasonality, and the random sampling frequency. Impacts from surface contamination or contaminated ground water are not evident in surface water quality, though the limited sampling is not conclusive.

A comparison of surface water quality data to available surface water criteria suggests that Heart River water quality would not pose a risk to biota (Table 7.3). The list of ground water constituents above background levels on-site was used in the comparison for consistency. 
Table 7.2 Comparison of contaminants above background levels in ground water at the site with available surface water quality values, Belfield UMTRA Project site, Belfield, North Dakota

\begin{tabular}{|c|c|c|c|}
\hline $\begin{array}{l}\text { Contaminant } \\
\text { above background } \\
\text { lovels in ground } \\
\text { water } \\
\end{array}$ & $\begin{array}{c}\text { Maximum concentration } \\
\text { in ground water } \\
\text { ( } \mathrm{mg} / \mathrm{L})\end{array}$ & $\begin{array}{c}\text { Water quality } \\
\text { criteria } \\
(\mathrm{mg} / \mathrm{L})^{\mathrm{a}}\end{array}$ & $\begin{array}{l}\text { Water } \\
\text { concentration } \\
\text { protective of } \\
\text { livestock } \\
\text { (mg/L) })^{\mathbf{b}}\end{array}$ \\
\hline Calcium & 602 & NA & NA \\
\hline Strontium & 0.10 & NA & NA \\
\hline Uranium & 0.106 & $11^{c}$ & NA \\
\hline Aluminum & 0.31 & 1.0 & 5.0 \\
\hline Barium & 0.10 & 1.0 & NA \\
\hline Chloride & 755 & 100 & NA \\
\hline Copper & 0.05 & 18 & 0.5 \\
\hline Magnesium & 298 & NA & NA \\
\hline Silver & 0.03 & NA & NA \\
\hline Vanadium & 0.10 & NA & 0.1 \\
\hline
\end{tabular}

a Standards of water quality for the state of North Dakota (NDSDH, 1991).

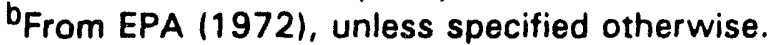

${ }^{c}$ Hardness-based standard from the state of Colorado (CDH, 1991).

NA - not available. 
Table 7.3 Comparison if surface water concentrations of ground water contaminants above background levels at the site with available surface water quality values for livestock. Belfield UMTRA Project site. Belfield, North Dakota

\begin{tabular}{|c|c|c|c|}
\hline \multirow[b]{2}{*}{ Constituent } & \multicolumn{2}{|c|}{$\begin{array}{l}\text { Maximum concentration detected in } \\
\text { North Branch of Heart River ( } \mathrm{mg} / \mathrm{L} \text { ) }\end{array}$} & \multirow{2}{*}{$\begin{array}{c}\text { Water quality criteria } \\
\text { protective of livestock } \\
(\mathrm{mg} / \mathrm{L})^{\mathbf{a}}\end{array}$} \\
\hline & Upstream location & Adjacent locations & \\
\hline Uranium & 0.09 & 0.07 & NA \\
\hline Aluminum & 0.50 & 0.40 & 5.0 \\
\hline Barium & 0.06 & 0.04 & NA \\
\hline Calcium & 480 & 641 & NA \\
\hline Copper & 0.01 & 0.02 & 0.5 \\
\hline Chloride & 715 & 86 & NA \\
\hline Magnesium & 421 & 425 & NA \\
\hline Silver & 0.02 & 0.02 & NA \\
\hline Strontium & 2.8 & 5.0 & NA \\
\hline Vanadium & 0.07 & 0.07 & 0.1 \\
\hline
\end{tabular}

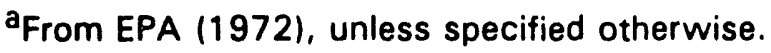

NA - Not available. 
The state of North Dakota's standards for water quality contain provisions for the use of background water quality in assessing outside influences. This is applicable in specific situations, where waters may contain natural chemical, physical, or biological characteristics exceeding the limits of the standards (NDSDH, 1991). Although this does not change the health risk evaluation, it does take into account the natural variability in water quality, which for the Belfield site likely results from turbid surface water conditions and random sampling frequencies. Understanding the natural variability in water quality in the Heart River is necessary to evaluate chronic exposure and risk, especially since exposure to surface water at the site is sporadic because the river is dry most of the year.

\section{Heart River sediments}

Sediment samples collected from the Heart River were analyzed for chromium, selenium, uranium, and molybdenum (Table 7.4). This list of analytes was selected before this risk assessment was developed. No state or federal sediment quality criteria (SOC) are established for the protection of aquatic life for these constituents (EPA, 1988). Site-specific BCFs for ingestion of and dermal contact with soils are unavailable. Generic BCFs are not applicable.

The EPA is evaluating a methodology based on a three-phase sorption model for free metal ion activity and is assessing its applicability for determining the bioavailable fraction within sediments (EPA, 1989c). Currently, a number of other predictive models and methods are being investigated for metals, but no single approach has been accepted to adequately develop sediment-based metals criteria (Shea, 1988; Chapman, 1989; EPA, 1989c; NOAA, 1990; Di Toro et al., 1991; Burton, 1991). Therefore, only a qualitative hazard assessment of the metals detected in sediments will be presented in this environmental evaluation.

National Oceanic and Atmospheric Administration (NOAA) effects-based sediment quality values are available for evaluating the potential for constituents in sediment to cause adverse biological effects. These values are not standards or criteria. Effects range-low (ER-L) values are concentrations equivalent to the lower 10th percentile of available data screened by the NOAA. These values indicate the low end of the range of concentrations in specific sediments at which adverse biological effects were observed or predicted in sensitive species and/or life stages. The effects range-median (ER-M) values are concentrations based on the NOAA-screened data at which effects were observed or predicted in 50 percent of the test organisms evaluated. The NOAA ER-L and ER-M values were compared with the concentrations of metals monitored for in sediment at the site. The ER-L and ER-M provide limited information and cannot be used as direct indicators of adverse effects to aquatic organisms. Of the constituents measured in sediment, NOAA sediment quality values are available only for chromium. 


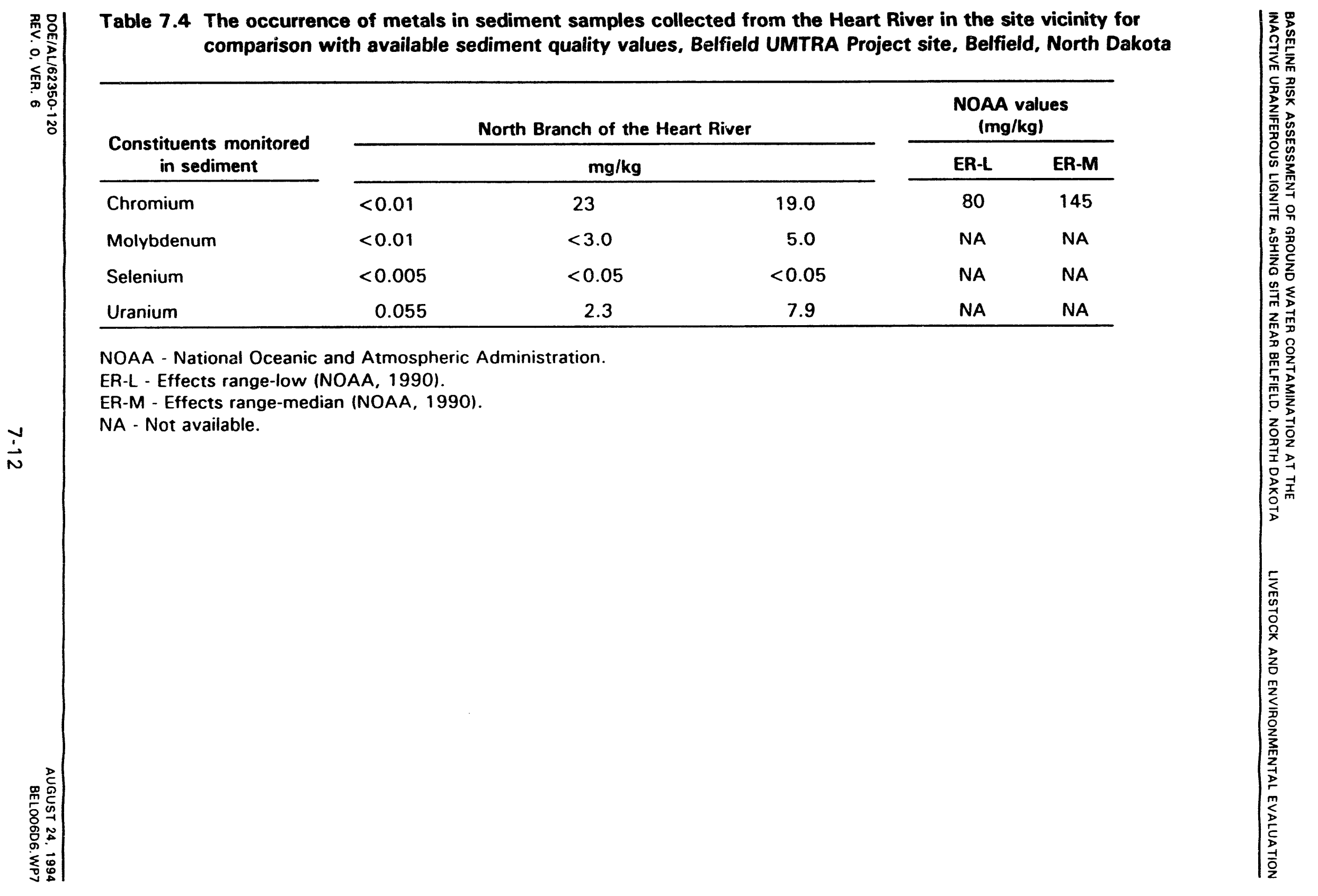


The chromium concentrations upstream and adjacent to the site are below; the NOAA ER-L value $(80 \mathrm{mg} / \mathrm{kg})$, and NOAA ER-M value $(145 \mathrm{mg} / \mathrm{kg}$ ) (Table 7.4$)$. This suggests that the potential for chromium to represent a hazard to aquatic life is low. Because there are no sediment quality values for molybdenum, selenium, and uranium, it is not possible to completely evaluate the potential for adverse effects on biota from exposure to sediment. Concentrations for these metals were within the concentration ranges known to occur in soils of the western United States (USGS, 1984). These data suggest that the site is not acting as a significant release source to the river for sediment-bound metals.

\subsection{POTENTIAL IMPACTS TO LIVESTOCK}

The potential exists for livestock to drink water directly from the Heart River or from a water source supplied by a hypothetical well intercepting contaminated ground water. The potential for adverse impacts to livestock from these drinking water pathways was evaluated in Section 7.4. The comparison of contaminant concentrations in ground water to surface water quality criteria for biota and drinking water standards specific to livestock (Table 7.2) provides a an estimation of potential risk to livestock. Potential risks to livestock from drinking contaminated ground water at the site would not be expected as a result of the processing site constituents of potential concern. Potential risks from background ground water were not quantified but would be expected to be greater than those attributable to the site.

Water in the Heart River is sporadic and absent most of the year. Surface water quality data used in the assessment represents water quality in the river during dry periods when concentrations of constituents are increased. Constituent concentrations would be greatly diluted during periods of flow, which is when livestock would be likely to drink the water. Therefore, potential risks from surface water are less likely than those for ground water.

\subsection{UNCERTAINTIES OF THE ECOLOGICAL RISK ASSESSMENT}

The qualitative evaluation of potential ecological risks presented here is a screening level assessment of the risks associated with potential exposure of plants and animals to contaminated ground water, surface water, and sediment at the Belfield site. Sources of uncertainty in any ecological assessment arise from monitoring data, 3xposure assessments, toxicological information, and inherent complexities of the ecosystem. In addition, methods of predicting nonchemical stresses (e.g., drought), biotic interactions, behavior patterns, biological variability (i.e., differences in physical conditions and nutrient availability), and resiliency and recovery capacities are often unavailable.

\subsection{SUMMARY}

Surface water quality and sediment quality data were insufficient for a comprehensive evaluation of potential impacts to the environment. However, 
the qualitative assessment conducted does suggest that the site is not acting as a source of surface water contamination or sediment-bound metals.

A comparative evaluation of potential exposure by biota to contaminants in ground water can provide some insight into the potential for adverse impacts. Additional monitoring could provide information on possible temporal and seasonal variations in water and sediment quality to better quantify risk. However, based on available data and criteria, no immediate threat to wildlife, plants, or livestock exists.

Livestock may be more susceptible to levels of constituents detected in background ground water. Therefore, there is the potential for adverse impacts to biota from exposure to background ground water, regardless of any added risks attributable to the site. Risk from background ground water was not quantified. 


\subsection{INTERPRETATION AND RECOMMENDATIONS}

\subsection{RISK SUMMARY}

The UMTRCA requires the UMTRA Project to protect public health and the environment from radiological and nonradiological hazards associated with the uranium mill sites. This baseline risk assessment was conducted for the Belfield site to evaluate the presence of hazards attributable to the ashing process.

No human health or environmental risks were identified for exposure to the contaminants of potential concern in ground water at the Belfield site (uranium and vanadium). Noncarcinogenic health impacts would not be expected, and the lifetime excess cancer risk associated with uranium and its radioactive longer-lived progeny is within the EPA's acceptable range.

Some constituents (antimony, boron, cadmium, chromium, lead, molybdenum, selenium, and sulfate) in the background ground water are at levels above the health advisory levels and/or EPA MCLs. The potential for toxicity from constituents in background ground water was not quantified. However, the greatest risks from the ingestion of shallow ground water in the site vicinity would be from background concentrations of constituents and not the incremental risk contributed by uranium and vanadium at the site.

\subsection{LIMITATIONS OF THIS RISK ASSESSMENT}

\section{Human health risk}

The evaluation of human health risks is limited by the following:

- This document evaluates risks associated with exposures only to inorganic contaminants of ground water at the UMTRA Project site near Belfield. Organic contaminants are not expected at the Belfield site.

- The results presented in this document are based on filtered (0.45-micrometer filter) water samples. The effect of filtration differs for different elements. Filtered samples can have somewhat lower concentrations than unfiltered samples for some constituents. Constituents in suspension may be lost with filtration but could still produce toxic effects if ingested and broken down in the acidic environment of the stomach. However, nothing in the unfiltered data suggests that any contaminants of potential concern were missed by using filtered data.

- The toxicity of any contaminant varies from individual to individual. By using probability distributions for potential exposure and presenting ranges of exposures that can produce toxic effects, this assessment tries to emphasize that variability. The document aims to provide the reader with a better understanding of the likelihood of toxicity. However, it is not 
possible to account for all sources of variability and still present useful and meaningful analyses.

- To assess toxicity, standardized reference values developed by agencies such as the EPA are used to determine plant uptake, tissue concentrations in livestock, and toxic effects in humans. These reference values themselves have limitations, including the following:

- Not all constituents elevated above background levels at the site have toxicity, uptake, and bioconcentration data available.

- In some cases, data obtained from laboratory animal testing at exposure doses different from those expected at the site were used to determine toxicity. The relationship between dose and response is not always linear, and humans do not always exhibit the same responses as animals.

- Data used to determine toxicity are generally based on exposure to only the contaminant of potential concern. In reality, exposures generally occur simultaneously to several chemicals. The interactive effects of multiple constituents and the impact of these interactions on expected toxicity generally cannot be accurately assessed from existing data.

- Considerable effort has been directed at determining plume location and placing monitor wells in locations that capture maximal contamination. However, variability in physical systems and models used to determine the location of the contaminant plume could still result in well placements that do not measure the highest contaminant concentrations or determine the fullest extent of the plume.

- Variability can be introduced through sampling and analytical processes. However, the data at UMTRA Project sites have been collected over many years and subjected to rigorous quality assurance procedures. The use of multiple samples introduces high confidence in the reliability and validity of the collected data.

- The drinking water pathway is considered the major determinant of exposure in this assessment. Although other pathways were screened and determined not to contribute significantly to the total exposure, the additivity of exposure from these pathways should be kept in mind. No other pathways increased expected exposures significantly enough to alter the predicted toxicity.

By presenting ranges of toxic effects, summaries of available data on health effects and interactions, and outlines of potential limitations, this document provides a reasonable interpretation of potential health risks associated with ground water contamination at this site. This assessment presents both 
contamination and risk as accurately as possible, based on available data, and conveys areas of uncertainty.

\section{Ecological risk}

In general, limitations for the Belfield ecological risk assessment include the following:

- Only a small amount of ecological data were available for this screening.

- Little is known about site-specific intake rates for wildife or amounts of contaminants taken up by plants. Therefore, detailed assessments were not possible.

- Potential risks from exposure to background concentrations of constituents were not quantified.

- Only limited ecotoxicological reference data are available.

- Considerable uncertainty is associated with the toxicity of mixtures of contaminants.

- Uncertainties are associated with the interpretation of surface and ground water quality data, given the significant potential for natural variability due to seasonal and geologic influences on water quality.

\section{GROUND WATER CRITERIA}

In 1983, the EPA established health and environmental protection standards for the UMTRA Project, and in 1987 the EPA proposed revised ground water standards in the UMTRCA. The UMTRA Project is required to adhere to the 1987 proposed ground water standards until final standards are published. The UMTRCA ground water standards consist of 1) ground water protection standards to evaluate disposal cell performance, and 2) ground water cleanup standards for existing contamination at processing sites. These standards are summarized in Table $\mathbf{8 . 1}$ for constituents that have a proposed MCL. A constituent's MCL or site-specific background concentration becomes the applicable standard. Background concentrations are used as the initial screening criteria to evaluate site-related contamination at UMTRA Project sites. While only the UMTRCA standards apply to the UMTRA Project, the EPA also has published drinking water health advisory levels for both long-and short-term exposures, which are also listed in Table 8.1.

The two contaminants of potential concern, uranium and vanadium, do not exceed these criteria. However, several metals present in background water quality in the Belfield site vicinity exceed the $\mathrm{MCL}$ and/or the health advisory levels. Because on-site concentrations of these metals did not statistically exceed background levels, they were not included on the list of contaminants of 
Table 8.1 Concentration limits

\begin{tabular}{|c|c|c|c|}
\hline Constituent & $\begin{array}{c}\text { UMTRCA MCL } \\
40 \mathrm{CFR} \$ 192.02 \\
(\mathrm{mg} / \mathrm{L}) \\
\end{array}$ & $\begin{array}{c}\text { EPA health advisories } \\
10-\mathrm{kg} \text { child, 10-day } \\
\text { (mg/L) }\end{array}$ & $\begin{array}{c}\text { EPA health advisories } \\
70-\mathrm{kg} \text { adult, lifetime } \\
\text { (mg/L) }\end{array}$ \\
\hline \multicolumn{4}{|l|}{ Chemicals (inorganic) } \\
\hline Antimony & - & 0.015 & 0.003 \\
\hline Arsenic & 0.05 & - & - \\
\hline Barium & 1.0 & - & 2 \\
\hline Boron & - & 0.9 & 0.6 \\
\hline Cadmium & 0.01 & 0.04 & 0.005 \\
\hline Chromium & 0.05 & 1.0 & 0.1 \\
\hline Cobalt & - & - & - \\
\hline Copper & - & - & - \\
\hline Fluoride & - & - & - \\
\hline Iron & - & - & - \\
\hline Lead & 0.05 & - & 0.015 \\
\hline Manganese & - & - & - \\
\hline Mercury & 0.002 & - & - \\
\hline Molybdenum & 0.1 & 0.08 & 0.04 \\
\hline Nickel & - & 1.0 & 0.1 \\
\hline Nitrate & $44^{a}$ & $44^{b}$ & - \\
\hline Selenium & 0.01 & - & - \\
\hline Silver & 0.05 & 0.2 & 0.1 \\
\hline Strontium & - & 25 & 17 \\
\hline Sulfate & - & - & - \\
\hline Thallium & $\cdot$ & 0.007 & 0.0004 \\
\hline Vanadium & - & 0.08 & 0.02 \\
\hline Zinc & - & 6.0 & 2 \\
\hline \multicolumn{4}{|l|}{ Radionuclides } \\
\hline Lead-210 & - & - & - \\
\hline Polonium-210 & - & - & - \\
\hline Radium-226/-228 & $5 \mathrm{pCi} / \mathrm{L}$ & - & - \\
\hline Thorium-230 & - & - & - \\
\hline $\begin{array}{l}\text { Uranium } \\
(U-234 /-238)\end{array}$ & $\begin{array}{c}30 \mathrm{pCi} / \mathrm{L} \\
(0.044 \mathrm{mg} / \mathrm{L})\end{array}$ & $0.03 \mathrm{mg} / \mathrm{L}^{\mathrm{b}, \mathrm{c}}$ & $0.1 \mathrm{mg} / \mathrm{L}^{\mathrm{b}}$ \\
\hline
\end{tabular}

$N A=$ No RfD available with which to calculate a health-based concentration.

aEqual to $10 \mathrm{mg} / \mathrm{L}$ nitrate as nitrogen.

bProposed values; under review.

'Exceeded in plume well 520 and in background. 
potential concern for site-related health risks. Metal constituents in background water that exceed the MCL or health advisory are antimony, boron, cadmium, chromium, lead, molybdenum, selenium, and sulfate.

\subsection{RISK MITIGATION MEASURES}

No current potential human health risk exists from short- or long-term use of contaminated ground water from the upper aquifer below the Belfield former ashing site. The city of Belfield is $0.5 \mathrm{mi}(0.8 \mathrm{~km})$ northwest of the processing site in Stark County, North Dakota; the contaminated zone is not known to have moved off-site. If contamination were to move off-site, it would move south/southeast, away from the city. Although the upper aquifer is not used as a public drinking water supply, it is used for watering livestock and is known to be a drinking water source for one residence located $1 \mathrm{mi}(1.6 \mathrm{~km})$ southeast of the site. This section presents possible ways to restrict access to ground water if it were necessary to mitigate risk in the future.

Institutional controls are defined in the preamble to the proposed ground water standards for the UMTRA Project as mechanisms that can be used effectively to protect human health and the environment by controlling access to contaminated ground water (52 FR 36000). Although the preamble refers to institutional controls for long time periods (e.g., up to 100 years during natural flushing), this concept also can be applied to short-term or interim restrictions of access to ground water.

The state of North Dakota Ground Water Protection Act 123 N.D. Century Code Ann. \$33.06) authorizes the Department of Health to conduct ground water quality monitoring in cooperation with the state engineer and other state agencies. Based on monitoring results, the department must implement or require mitigation activities or remedial action to prevent future ground water contamination. The health department also is responsible for protecting the health of the state's citizens. It can advise people that the water in their wells is known to be contaminated but cannot restrict or notate deeds (Glatt, 1994).

Water permits are required for all wells except domestic wells that draw less than 12.5 acre-feet per year and wells used for livestock watering that draw less than 12.5 acre-feet per year. The permits ensure proper construction of wells and acceptable quantity of water withdrawal. The State Engineer's office may evaluate a permitted well based on the quality of water, but water quality is not part of the permitting evaluation. Domestic and agricultural wells are not permitted through the State Engineer's office (Linden, 1994). Stark County requires that new domestic and agricultural wells be approved by Southwest District Health Unit sanitarians (Herring, 1994).

The Stark County Water Resource Board cannot restrict use of ground water, but it can inform the health department of any problems that may be harmful to the public (Kessel, 1994). 
The Southwest District Health Unit has the most access to existing and new ground water well users in the state. The health unit has jurisdiction over eight counties, including Stark County, and has county maps with landowners identified. In the event a health advisory is necessary, sanitarians would visit or call county residents to issue the health advisory (Herring, 1994).

\subsection{FUTURE SITE ACTIVITIES}

Most site characterization activities conducted to date at the Belfield site were intended to provide sufficient preliminary site characterization information to design and implement a surface remediation plan. Further characterization activities may be needed for the ground water remediation phase of the UMTRA Project. Plans for surface and ground water remedial action at the Belfield site are currently under review by the DOE and the state of North Dakota.

\subsection{RECOMMENDATIONS}

In general, the proposed ground water standards consisting of MCLs or background concentrations are sufficient to protect human health and the environment. However, in some cases, a risk assessment may identify site-specific factors suggesting these standards may be either too restrictive or not restrictive enough. When standards are too restrictive, there may be no potential for adverse effects at the estimated exposures, and a less restrictive alternate concentration limit (ACL) may be sought. In other cases, the standards may not be sufficiently protective (e.g., if several contaminants are at or near the MCL and additive or synergistic adverse health effects are expected).

Many trace metals present at the site, although above MCLs, were not statistically above background levels. Therefore, these constituents are not considered site-related contaminants of potential concern and may qualify for no remedial action. Constituents identified as above background levels on-site were further screened for toxicity (Section 3.3). Several constituents were removed from the list of contaminants of potential concern for human health because estimated exposures were within nutritional or dietary levels. Constituents such as strontium were also removed from the list because exposure levels were determined to be at concentrations well below adverse health effect levels. These constituents would qualify for ACLs. The two metal constituents that were evaluated as constituents of potential concern for human health, uranium and vanadium, were also determined to be below adverse effect levels and should also qualify for ACLs.

Although levels of site-related contaminants are below those that cause adverse health effects, the background water quality poses a potential risk, and no permanent physical barrier is present to prevent access to contaminated ground water at or near the former ashing site. Some form of institutional controls could be considered, although the regulatory need for such controls as they relate to natural background contamination is outside the purview of the 
UMTRCA. These controls would help to inform potential well users of the poor water quality known to exist, both from the site and from natural sources.

Currently, there are no ground water pathways to biota, which substantially reduces the potential for adverse impacts from previous site activities. Although impacts to surface water from site contamination were not clearly identifiable, the potential risks from background ground water (even if a pathway existed) likely would pose a greater threat to ecological receptors than the site-related incremental risk from uranium and vanadium. 


\subsection{LIST OF CONTRIBUTORS}

The following individuals contributed to the preparation of this report.

\begin{tabular}{ll}
\hline Name & Contribution \\
\hline M. Day & $\begin{array}{l}\text { Overall document responsibility; authorship; } \\
\text { ecological assessment } \\
\text { K. Smith }\end{array}$ \\
Statistical evaluation \\
D. Heydenburg & Hydrogeology, surface water \\
A. Groffman & Geochemistry \\
M. Gawthrop & Institutional controls \\
B. Toth & Toxicology \\
L. Sanchez, L. Keith, C. Slosberg & Word processing \\
E. Bond & Graphic design \\
D. Thalley & Technical editing \\
\hline
\end{tabular}




\subsection{REFERENCES}

Aiyar, A. S., and A. Sreenivasan, 1961. Proceedings from the Society of Experimental Biology and Medicine, Vol. 107, pp. 914-916.

Allison et al. (J. D. Allison, D. S. Brown, and K. J. Novo-Gradac), 1991. MINEOA2/PRODEFA2, A Geochemical Assessment Model for Environmental Systems: Version 3.0 User's Manual, EPA/600/3-91/021, Environmental Research Laboratory, Office of Research and Development, U.S. Environmental Protection Agency, Athens, Georgia.

Baes et al. (C. F. Baes III, R. D. Sharp, A. L. Sjoreen, and R. W. Shor), 1984. A Review and Analysis of Parameters for Assessing Transport of Environmentally Released Radionuclides Through Agriculture, ORNL-5786, prepared for Oak Ridge National Laboratory, Health and Safety Research Division, Oak Ridge, Tennessee.

Ballou et al. (J. E. Ballou, R. A. Gies, A. C. Case, D. L. Haggard, R. L. Buschbom, and J. L. Ryan), 1986. "Deposition and Early Disposition of Inhaled Uranium-233 Uranyl Nitrate and Uranium-232 Uranyl Nitrate in the Rat," Health Physics, No. 51, pp. 755-772.

Belehova, B. A., 1969. Scientific Transactions of the Irkutsk State Medical Institute, Vol. 96. pp. 20-23 (in Russian).

Berlin, M., and B. Rudell, 1986. "Uranium," in Handbook on the Toxicology of Metals, second edition, L. Friberg, G. F. Nordberg, and V. B. Vouk, eds., pp. 647-658, Elsevier Science Publishers, Amsterdam.

Bowman, D., 1986. U.S. Fish and Wildlife Service, Grand Island, Nebraska, personal communication with David Lechel, Manager of Environmental Services, Jacobs Engineering Group Inc., Albuquerque, New Mexico, UPDCC File Location No. 21.15.1.4, February 4, 1986.

Burton, G. A., Jr., 1991. "Assessing the Toxicity of Freshwater Sediments," Environmental Toxicology and Chemistry, No. 10, pp. 1585-1627.

Byerrum et al. (R. U. Byerrum, R. E. Eckardt, L. L. Hopkins), 1974. Vanadium, National Academy of Sciences, Washington, D.C.

Byrne, A. R., and L. Kosta, 1978. Sci. Total Environ., Vol. 10, pp. 17-30.

CDH (Colorado Department of Health), 1991. Basic Standards and Methodologies for Surface Water, 3.1.0., Water Quality Control Commission, Denver, Colorado.

Casarett, L. J., and J. Doull, 1991. Toxicology: The Basic Science of Poisons, fourth edition, M. O. Amdur, J. Doull, and C. D. Klaassen, eds., Pergamon Press, New York, New York. 
Chapman, P. M., 1989. "Current Approaches to Developing Sediment Quality Criteria," Environmental Toxicology and Chemistry, No. 8, pp. 598-599.

Collins, R., 1987. U.S. Fish and Wildlife Service, Bismarck, North Dakota, personal communication with C.H. Persson-Reeves, Environmental Services, Jacobs Engineering Group Inc., Albuquerque, New Mexico, October 30, 1987.

Cothern, C. R., and W. L. Lappenbusch, 1983. "Occurrence of Uranium in Drinking Water in the United States," Health Physics, No. 45, pp. 89-99.

Curran et al. (G. L. Curran, D. L. Azarnoff, and R. E. Bolinger), 1959. Journal of Clinical Investigation, Vol. 38, pp. 1251-1261.

Denson et al. (N. M. Denson, G. O. Bachman, and H. D. Zeller), 1959. "Uranium-Bearing Lignite in Northwestern South Dakota and Adjacent States," U.S. Geological Survey Bulletin 1055-B, pp. 11-57.

DHHS (U.S. Department of Health and Human Services), 1993. Toxicological Profile for Cadmium, prepared by Life Systems, Inc. for the U.S. Department of Health and Human Services, Public Health Service, Agency for Toxic Substances and Disease Registry.

DHHS (U.S. Department of Health and Human Services), 1992. Toxicological Profile for Copper, prepared by Syracuse Research Corp. for the U.S. Department of Health and Human Services, Public Health Service, Agency for Toxic Substances and Disease Registry.

Dimond et al. (E. G. Dimond, J. Caravaca, and A. Benchimol), 1963. "Vanadium: Excretion, Toxicity, Lipid Effect in Man," American Journal of Clinical Nutrition, Vol. 12, pp. 49-53.

Disbro, S., 1986. U.S. Army Corps of Engineers, Omaha, Nebraska, personal communication with Charles Burt, Regulatory Compliance Department, Jacobs Engineering Group Inc., Albuquerque, New Mexico, UPDCC File Location No. 21.15.1.3, March 6, 1986.

Di Toro et al. (D. M. Di Toro, C. S. Zarba, D. J. Hansen, W. J. Berry, R. C. Swartz, C. E. Cowan, S. P. Pavlou, H. E. Allen, N. A. Thomas, and P. R. Paquin), 1991. "Technical Basis for Establishing Sediment Quality Criteria for Nonionic Organic Chemicals Using Equilibrium Partitioning," Environmental Toxicology and Chemistry, No. 10, pp. 1541-1583.

DOE (U.S. Department of Energy), 1994. "Draft Programmatic Environmental Impact Statement for the Uranium Mill Tailings Remedial Action Ground Water Project," DOE/EIS-0198, Rev. 3, April 1994, prepared by the U.S. Department of Energy, UMTRA Project Office, Albuquerque Operations Office, Albuquerque, New Mexico. 
DOE (U.S. Department of Energy), 1993. Environmental Assessment of Remedial Action at the Inactive Uraniferous Lignite Ashing Sites at Belfield and Bowman, North Dakota, DOE/EA-0326, September 1993, prepared by the U.S. Department of Energy, UMTRA Project Office, Albuquerque Operations Office, Albuquerque, New Mexico.

DOE (U.S. Department of Energy), 1992. Environmental Analysis and Data Report Prepared for the Environmental Assessment of Remedial Action at the Inactive Uraniferous Lignite Ashing Sites at Belfield and Bowman, North Dakota, final, DOE/AL-0346, September 1992, prepared by the U.S. Department of Energy, UMTRA Project Office, Albuquerque Operations Office, Albuquerque, New Mexico.

DOE (U.S. Department of Energy). 1991. Investigation of a Natural Geochemical Barrier, UMTRA-DOE/AL-400666.0000, February 1991, prepared by the U.S.

Department of Energy, UMTRA Project Office, Albuquerque Operations Office, Albuquerque, New Mexico.

DOE (U.S. Department of Energy), 1990. Remedial Action Plan for Stabilization of the Inactive Uraniferous Lignite Ashing Sites at Belfield and Bowman, North Dakota, final, UMTRA-DOE/AL-050522.0000, Volume I, prepared by the U.S. Department of Energy, UMTRA Project Office, Albuquerque Operations Office, Albuquerque, New Mexico.

Duel, M., and C. S. Annell, 1956. "Occurrence of Minor Elements in Ash of Low-Rank Coal From Texas, Colorado, North Dakota and South Dakota," United States Geological Survey Bulletin, 1036-H, pp. 155-172.

EPA (U.S. Environmental Protection Agency), 1993. Integrated Risk Information System (IRIS), data base, Office of Research and Development, Washington, D.C.

EPA (U.S. Environmental Protection Agency), 1992. Health Effects Assessment Summary Tables, OHEA ECAO-CIN-821, March 1992, Office of Research and Development, Office of Emergency and Remedial Response, Washington, D.C.

EPA (U.S. Environmental Protection Agency), 1991. Human Health Evaluation Manual, supplemental guidance, "Standard Default Exposure Factors," U.S. Environmental Protection Agency, Washington, D.C.

EPA (U.S. Environmental Protection Agency), 1989a. Risk Assessment Guidance for Superfund, Vol. I, Human Health Evaluation Manual, EPA/540/1-89/002, Office of Emergency and Remedial Response, Washington, D.C.

EPA (U.S. Environmental Protection Agency), 1989b. Risk Assessment Guidance for Superfund, Vol. II, Environmental Evaluation Manual, EPA/540/1-89/001, Office of Emergency and Remedial Response, Washington, D.C. 
EPA (U.S. Environmental Protection Agency), 1989c. "Briefing Report to the EPA Science Advisory Board on the Equilibrium Partitioning Approach to Generating Sediment Quality Criteria," Office of Water Regulations and Standards, Washington, D.C.

EPA (U.S. Environmental Protection Agency), 1988. Interim Sediment Quality Criteria Values for Nonpolar Hydrophobic Organic Contaminants, Office of Water Regulations and Standards, Washington, D.C.

EPA (U.S. Environmental Protection Agency), 1977. Scientific and Technical Assessment Report on Vanadium, EPA-600-6-77-002, U.S. Environmental Protection Agency, Washington, D.C.

EPA (U.S. Environmental Protection Agency), 1972. Water Quality Criteria, PB-236/199, National Academy of Sciences and National Academy of Engineering, Washington, D.C.

FBDU (Ford, Bacon and Davis Utah, Inc.), 1981. Engineering Assessment of Inactive Uranium Mill Tailings, Belfield Site, Belfield, North Dakota. DOE/UMT-0122, Salt Lake City, Utah.

Fisenne et al. (I. M. Fisenne, P. M. Perry, and N. H. Harley, 1988. "Uranium in Humans," Radiation Protection Dosimetry, No. 24, pp. 127-131.

Flanagan et al. (P. R. Flanagan, J. S. McLellan, J. Haist, M. G. Cherian, M. J. Chamberlain, and L. S. Valberg), 1978. Gastroenterology, Vol. 74, pp. 841-846.

Friberg et al. (L. Friberg, G. F. Nordberg, and V. B. Vouk), 1986. Handbook on the Toxicology of Metals, Volume II: Specific Metals, second edition, Elsevier, New York, New York.

Fulton, C. S., 1989. "The Hydrologic, Geologic and Geochemical Factors Affecting the Distribution of Sodium in Lignite in the Underwood Lignite Field in West Central North Dakota," Ph.D. thesis, University of Kentucky, 301 pages.

Fulton, C. S., and M. L. Jones, 1986. "Geological, Geochemical, and Hydrological Factors Affecting the Distribution of Sodium in Lignite in West-Central North Dakota," Thirteenth Biennial Lignite Symposium: Technology and Utilization of Low-Rank Coals, Bismarck, North Dakota, pp. 559-566.

Garrels, R. M., and C. L. Christ, 1965. Solutions, Minerals and Equilibria, Harper and Row, New York, New York.

Girard et al. (N. N. Girard, H. Goetz, and A. J. Bjugstad), 1984. "Upland Hardwood Habitat Types in Southwestern North Dakota," Wooded Draws: Characteristics and Values for the Northern Great Plains, South Dakota School of Mines and Technology, Great Plains Agricultural Council, Publication No. 111, Rapid City, South Dakota. 
Glatt, D., 1994. State Department of Health, Bismarck, North Dakota, personal communication with Malu Gawthrop-Cooper, Regulatory Compliance Department, Jacobs Engineering Group Inc., Albuquerque, New Mexico, UPDCC File Location No. 21.19.7, May 25, 1994.

Gosselin et al. (R. E. Gosselin, H. C. Hodge, and R. P. Smith), 1976. Clinical Toxicology of Commercial Products, fourth edition, Williams and Wilkins, Baltimore, Maryland.

Hadjimarkos, D. M., 1968. Adv. Oral Biol., Vol 3, pp. 253-292.

Hadjimarkos, D. M., 1966. Nature, Vol. 209, p. 1137.

Harris et al., 1984. (W. R. Harris, S. B. Friedman, and D. Silberman), 1984. Journal of Inorganic Biochemistry, Vol. 20, pp. 157-169.

Henegar, D. L., 1985. Commissioner, North Dakota Game and Fish Department, Bismarck, North Dakota, personal communication with Charles Burt, Regulatory Compliance Departmerit, Jacobs Engineering Group Inc., Albuquerque, New Mexico, UPDCC File Location No. 21.15.1.4, November 18, 1985.

Herring, R., 1994. Southwest District Health Unit, Belfield, North Dakota, personal communication with Malu Gawthrop-Cooper, Regulatory Compliance Department, Jacobs Engineering Group Inc., Albuquerque, New Mexico, UPDCC File Location No. 21.19.7, May 25, 1994.

Houghton et al. (R. L. Houghton, G. S. Anderson, S. R. Hill, J. L. Burges, J. D. Wald, D. P. Patrick, R. L. Hall, and J. D. Unseth), 1987. "Prevention of Groundwater Quality Degradation During Reclamation of a Uraniferous Lignite Mine, North Dakota," Proceedings of the Fourth Biennial Symposium on Surface Mining and Reclamation on the Great Plains, Reclamation Research Unit Report No. 8704.

ICRP (International Commission on Radiological Protection), 1960. ICRP Publ., 2.

Kabata-Pendias, A., and H. Pendias, 1992. Trace Elements in Soils and Plants, second edition, CRC Press, Boca Raton, Florida.

Karner et al. (F. R. Karner, H. H. Schobert, S. K. Falcone, and S. A. Vorres), 1986. "Elemental Distribution and Association with Inorganic and Organic Components in North Dakota Lignites," Mineral Matter and Coal, American Chemical Society, Washington D.C., pp. 70-89.

Kenaga, E. E., 1980. "Predicted Bioconcentration Factors and Soil Sorption Coefficients of Pesticides and Other Chemicals," Ecotoxicology and Environmental Safety, No. 4, pp. 26-38. 
Kessel, N., 1994. Stark County Resource Board, Belfield, North Dakota, personal communication with Malu Gawthrop-Cooper, Regulatory Compliance Department, Jacobs Engineering Group Inc., Albuquerque, New Mexico, UPDCC File Location No. 21.19.7, May 25, 1994.

Kuchler, A. W., 1975. "Potential Natural Vegetation of the Conterminous United States," American Geographic Society, Special Publication No. 36. New York, New York (Map).

Lagerkvist et al. (B. Lagerkvist, G. F. Nordberg, and V. Vouk), 1986. "Vanadium," Handbook on the Toxicology of Metals, second edition, L. Friberg, G. F. Nordberg, and V. Vouk, eds., Elsevier Science Publishers, New York, New York.

Leach et al. (L. J. Leach, R. M. Gelein, B. J. Panner, C. L. Ylie, and C. C. Cox), 1984. The Acute Toxicity of the Hydrolysis Products of Uranium Hexafluoride (UF6) When Inhaled by the Rat and Guinea Pig, final report, ISS K/SUB-81-9039-3, National Technir,al Information Service, Springfield, Virginia.

Linden, M., 1994. State Department of Health, Bismarck, North Dakota, personal communication with Malu Gawthrop-Cooper, Regulatory Compliance Department, Jacobs Engineering Group Inc., Albuquerque, New Mexico, UPDCC File Location No. 21.19.7, May 25, 1994.

Maynard, E. A., and H. C. Hodge, 1949. "Study of Toxicity of Various Uranium Compounds When Fed to Experimental Animals," Pharmacology and Toxicology of Uranium Compounds, National Nuclear Energy Services, Div. VI, Vol. 1, pp. 309-376, C. Voegtlin and H. C. Hodge, eds., McGraw Hill, New York, New York.

Miller, R. N., and P. H. Given, 1986. "The Association of Major, Minor and Trace Inorganic Elements with Lignite, 1, Experimental Approach and Study of a North Dakota Lignite," Geochemica Cosmochemica Acta, Vol. 50, pp. 2033-2043.

Moore et al. (G. W. Moore, R. E. Melin, and R. C. Kepferle), 1959. "Uranium-Bearing Lignite in Southwestern North Dakota," Uranium in Coal in the Western United States, edited by Norman Denson. United States Geological Survey, Bulletin 1055, pp. 147-166.

NCRP (National Council on Radiation Protection and Measurements), 1984. "Exposures from the Uranium Series with Emphasis on Radon and its Daughter," NCRP Report No. 77, Bethesda, Maryland.

Nobel, E. A., 1972. "Metalliferous Lignite in North Dakota," North Dakota Geological Survey, Miscellaneous Services 50, pp. 133-134.

NOAA (National Oceanic and Atmospheric Administration), 1990. "The Potential for Biological Effects of Sediment-Sorbed Contaminants Tested in the National Status and Trends Program," NOAA technical memo, NOS OMA 52. 
Nordberg et al. (G. F. Nordberg, T. Kjellström, and M. Nordberg), 1985. Cadmium and Health: a Toxicological and Epidemiological Appraisal, Ch. 6, L. Friberg, C. G. Elinder, T. Kjellström, and G. F. Nordberg, eds., CRC Press, Boca Raton, Florida.

NDSDH (North Dakota State Department of Health), 1991. "Standards of Water Quality for the State of North Dakota," Rule 33-16-02, North Dakota State Department of Health, February 1, 1991, Bismarck, North Dakota.

Palisade Corporation, 1992. @RISK, Risk Analysis and Simulation Add-In for Lotus 1-2-3, Version 2.01, Newfield, New York.

Pennington, Jean A., and John W. Jones, 1987. "Molybdenum, Nickel, Cobalt, Vanadium, and Strontium in Total Diets," Journal of the American Dietetic Association, Vol. 87, No. 12, December 1987. American Dietetic Association, Division of Nutrition and Division of Contaminants Chemistry, Center for Food Safety and Applied Nutrition, Food and Drug Administration, Washington, D.C.

Perry et al. (H. M. Perry, Jr., S. Teitlebaum, and P. L. Schwartz), 1955. Federal Proceedings, Vol. 14, pp. 113-114.

PNL (Pacific Northwest Laboratory), 1989. "Sorption Distribution Coefficient Data," Multimedia Environmental Pollutant Assessment System, Pacific Northwest Laboratory, Richland, Washington.

Prister, B. S., 1969. GKIAE Report by Atomizdat, Moscow (Canadian translation AEC/TR/7178 (1970), and USCEAR Rep. A/AC.82/G/L 1298).

Proescher et al. (F. Proescher, H. A. Seil, and A. W. Stillians), 1917. Am. J. Syph., Vol. 1. pp. 347-405.

Rai, D., and J. M. Zachara, 1984. Chemical Attenuation Rates, Coefficients, and Constants in Leachate Migration Volume 1: A Critical Review, EPRI, EA-3356, Volume 1, Research Project 2188-1.

Roberts, K. D., 1994. "A Survey of Naturally Occurring Uranium in Groundwater in Southwestern North Dakota," Proceedings of North Dakota Water Quality, North Dakota State University Extension Service, Extension Agriculture Engineering Service, pp. 284-294.

Roseberry, A. M., and D. E. Burmaster, 1992. "Lognormal Distributions for Water Intake by Children and Adults," Risk Analysis, Vol. 12, No. 1, pp. 99-104.

Sapa, A. J., 1992. State Supervisor, U.S. Fish and Wildlife Service, Bismarck, North Dakota, personal communication with Bill Glover, Environmental Services, Jacobs Engineering Group Inc., Albuquerque, New Mexico, UPDCC File Location No. 21.15.1.4, March 30, 1992. 
Sapa, A. J., 1989. State Supervisor, U.S. Fish and Wildlife Service, Bismarck, North Dakota, personal communication with Bill Glover, Environmental Services, Jacobs Engineering Group Inc., Albuquerque, New Mexico, UPDCC File Location No. 21.15.1.4, May 31, 1989.

Schroeder et al. (H. A. Schroeder, J. J. Balassa, and I. H. Tipton), 1963. Journal of Chronic Diseases, Vol. 16, pp. 1047-1071.

Shea, D., 1988. "Developing National Sediment Quality Criteria," Environmental and Scientific Technology, No. 22(11), pp. 1256-1261.

Snyder, F., and W. E. Cornatzer, 1958. Nature, Vol. 182, pp. 462.

Somerville, J., and B. Davies, 1962. American Health Journal, Vol. 54, pp. 54-56.

Stevens et al. (W. F. Stevens, W. Bruenger, D. R. Atherton, J. M. Smith, and

G. N. Taylor), 1980. "The Distribution and Retention of Hexavalent ${ }^{233} \mathrm{U}$ in the Beagle," Radiation Research, No. 83, pp. 109-126.

Sullivan et al. (M. F. Sullivan, P. S. Ruemmler, J. L. Ryan, and R. L. Bushhom), 1986. "Influence of Oxidizing or Reducing Agents on Gastrointestinal Absorption of $U$, Pu, Am, Cm, and Pm by Rats," Health Physics, No. 50, pp. 223-232.

TAC (Technical Assistance Contractor), 1993. "Unpublished Field Notes, Belfield, North Dakota, Uranium Mill Tailings Site," unpublished report prepared by the TAC (Jacobs-Weston Team), Albuquerque, New Mexico, for the U.S. Department of Energy, UMTRA Project Office, Albuquerque Operations Office, Albuquerque, New Mexico.

TAC (Technical Assistance Contractor), 1992. "Unpublished Field Notes, Belfield, North Dakota, Uranium Mill Tailings Site," unpublished report prepared by the TAC (Jacobs-Weston Team), Albuquerque, New Mexico, for the U.S. Department of Energy, UMTRA Project Office, Albuquerque Operations Office, Albuquerque, New Mexico.

TAC (Technical Assistance Contractor), 1987. "Unpublished Field Notes, Belfield, North Dakota, Uranium Mill Tailings Site," unpublished report prepared by the TAC (Jacobs-Weston Team), Albuquerque, New Mexico, for the U.S. Department of Energy, UMTRA Project Office, Albuquerque Operations Office, Albuquerque, New Mexico.

TAC (Technical Assistance Contractor), 1986. "Unpublished Field Notes, Belfield, North Dakota, Uranium Mill Tailings Site," unpublished report prepared by the TAC (Jacobs-Weston Team), Albuquerque, New Mexico, for the U.S. Department of Energy, UMTRA Project Office, Albuquerque Operations Office, Albuquerque, New Mexico.

Tank, G., and C. A. Storvick, 1960. Journal of Dental Research, Vol. 39, pp. 473-488. 
Ting, F. T. C., and M. L. Jones, 1986. "Geochemistry of Sodium in North Dakota Lignite," Thirteenth Biennial Lignite Symposium: Technology and Utilization of Low-Rank Coals, Bismarck, North Dakota, pp. 589-599.

Tipton et al. (I. H. Tipton, P. L. Stewart, and J. Dickson), 1969. Health Physics, Vol. 9, pp. 103-145.

Tracy et al. (B. L. Tracy, J. M. Quinn, J. Lahey, A. P. Gilman, K. Mancuso, A. P. Yagdinas, and D. C. Villeneuve), 1992. "Absorption and Retention of Uranium from Drinking Water by Rats and Rabbits," Health Physics, Vol. 62, pp. 65-73.

Tracy et al. (B. L. Tracy, F. A. Prantl, and J. M. Quinn), 1983. "Transfer of ${ }^{226} \mathrm{Ra}{ }^{210} \mathrm{~Pb}$, and Uranium from Soil to Garden Produce: Assessment of Risk," Health Physics, Vol. 44, p. 469.

USGS (U.S. Geological Survey), 1984. "The Routine Mineralogical Analysis of Claybearing Samples," U.S. Geological Survey Bulletin 1563, 32 pages, Denver, Colorado.

Van Zinderen Bakker and J. F. Jaworski, 1980. Effects of Vanadium in the Canadian Environment, Ottawa, Canada: National Research Council Canada, Associate Committee Scientific Criteria for Environmental Quality.

Weigel, F., 1983. "Uranium and Uranium Compounds," Kirk-Othmer Encyclopedia of Chemical Technology, Vol. 23, third edition, pp. 502-547, M. Grayson, ed., John Wiley and Sons, New York, New York.

WHO (World Health Organization), 1988. Vanadium, Environmental Health Criteria 81 , published under the joint sponsorship of the United Nations Environment Programme, the International Labour Organisation, and the World Health Organization, Geneva, Switzerland.

Wrenn et al. (M. E. Wrenn, P. W. Durbin, B. Howard, J. Lipsztein, J. Rundo, E. T. Still, and D. L. Willis), 1985. "Metabolism of Ingested $U$ and Ra," Health Physics, No. 48, pp. 601-633.

Yakawa, M., and M. Suzuki-Yasumoto, 1980. Arch. Environ. Health, Vol. 35, pp. 36-44.

Zeller, H. D., and J. M. Schopf, 1959. "Core Drilling for Uranium-Bearing Lignite in Harding and Perkins Counties, South Dakota and Bowman County, North Dakota," United States Geolcgical Survey, Bulletin 1055-C, pp. 59-95.

Zschomier, M. S., 1986. U.S. Fish and Wildlife Service, Bismarck, North Dakota, personal communication with Charles Burt, Regulatory Compliance Department, Jacobs Engineering Group Inc., Albuquerque, New Mexico, UPDCC File Location No. 21.15.1.3, March 11, 1986. 


\section{UNITED STATES CODE}

42 USC $\$ 7901$ et seq., Uranium Mill Tailings Radiation Control Act, November 8, 1978.

\section{STATE CODE}

23 N.D. Century Code Ann. \$33.06, Ground Water Protection Act.

\section{CODE OF FEDERAL REGULATIONS}

40 CFR Part 192, Health and Environmental Protection Standards for Uranium and Thorium Mill Tailings, U.S. Environmental Protection Agency (1994).

\section{FEDERAL REGISTER}

52 FR 36000, Standards for Remedial Actions at Inactive Uranium Processing Sites; Proposed Rule, September 24, 1987. 

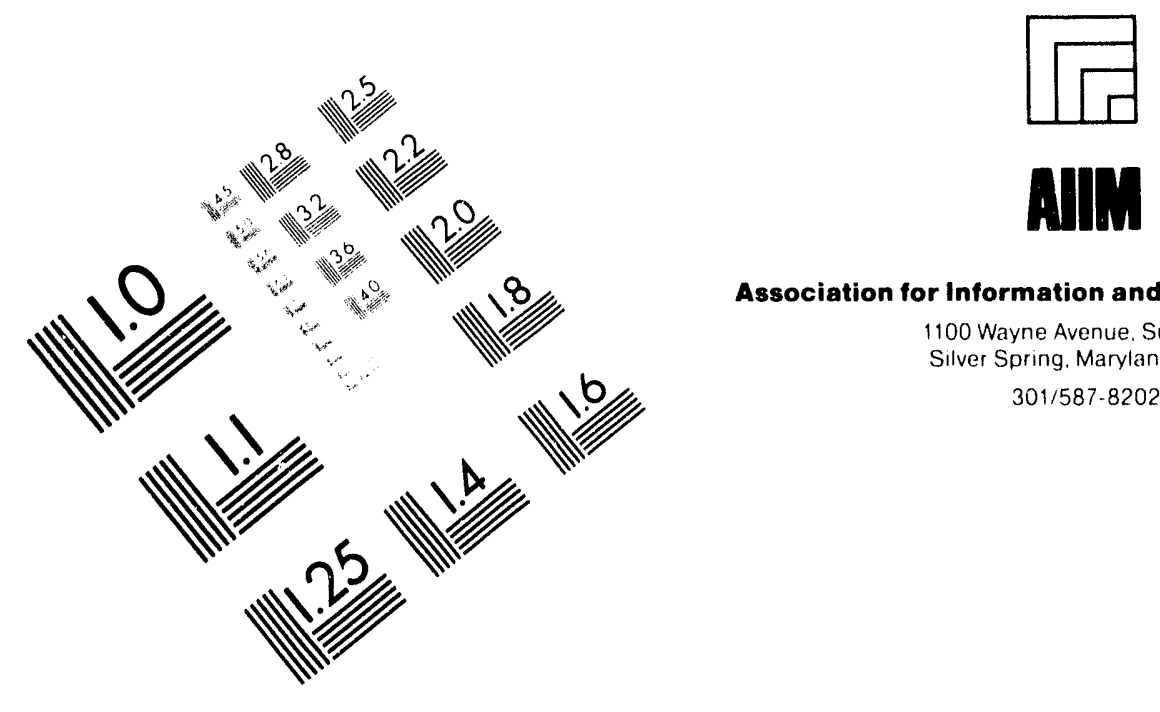

Association for Information and Image Management

1100 Wayne Avenue. Suite 1100
Silver Spring. Maryland 20910

301/587-8202

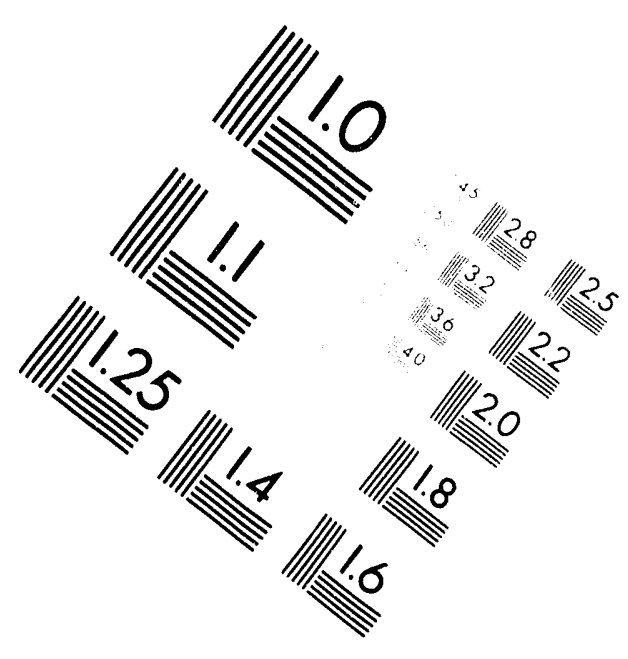

\section{Centimeter}

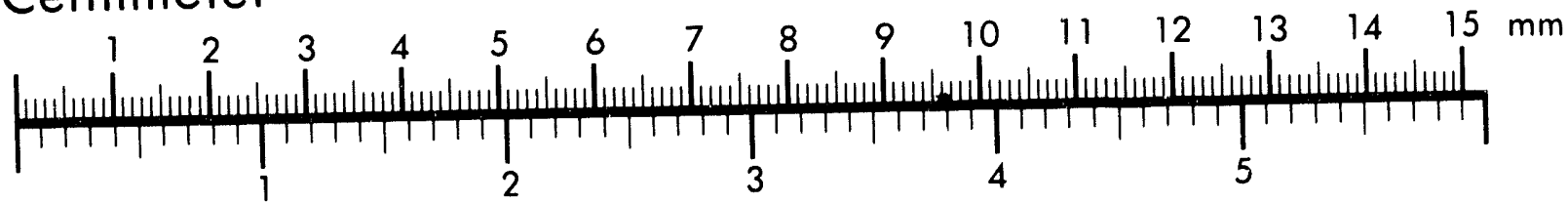

Inches
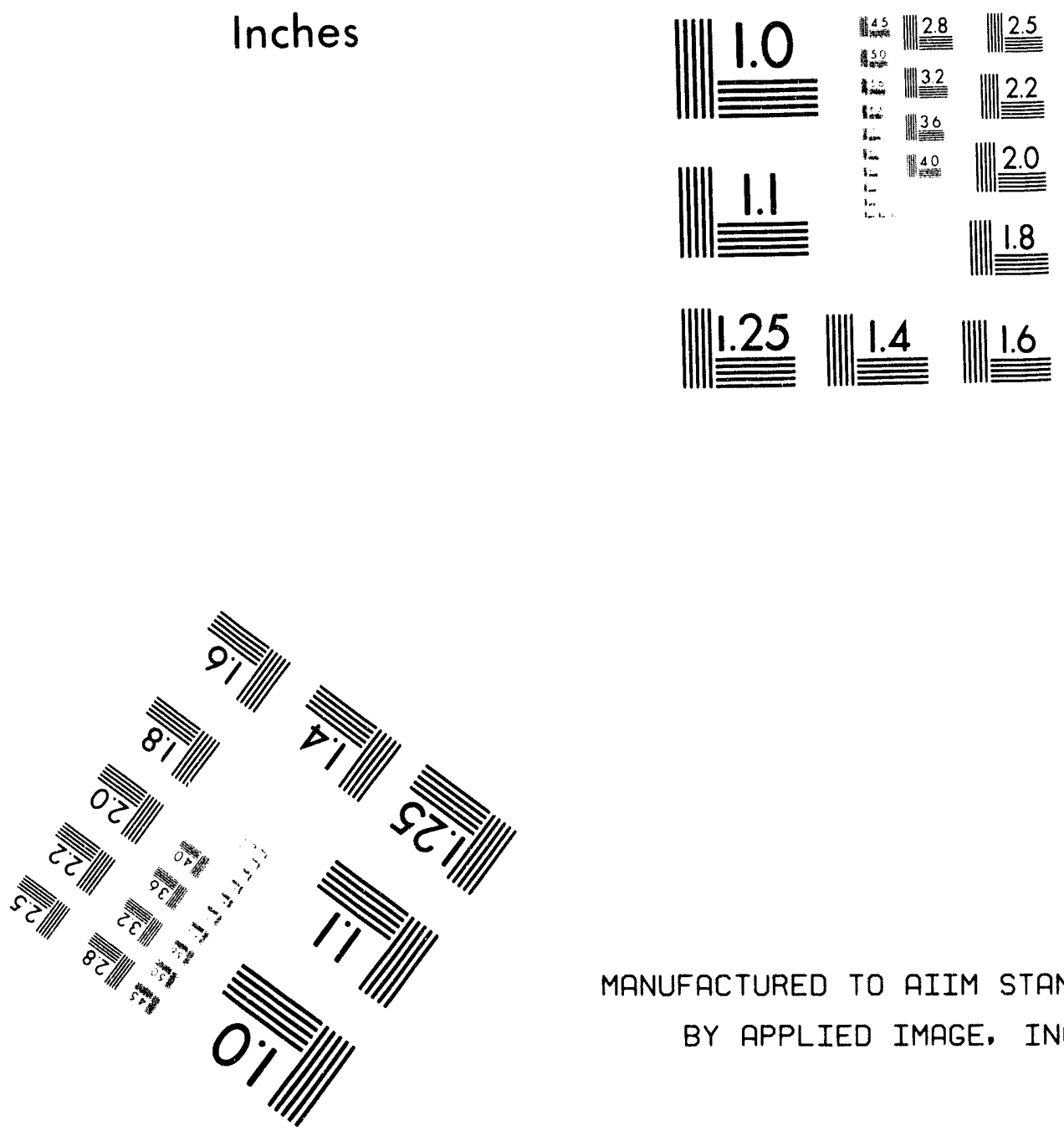

MANUFACTURED TO AIIM STANDARDS

BY APPLIED IMAGE. INC.

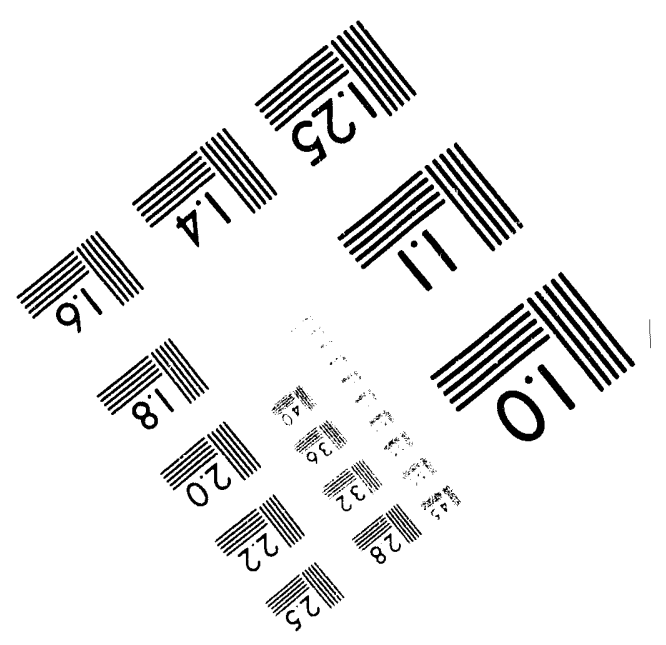




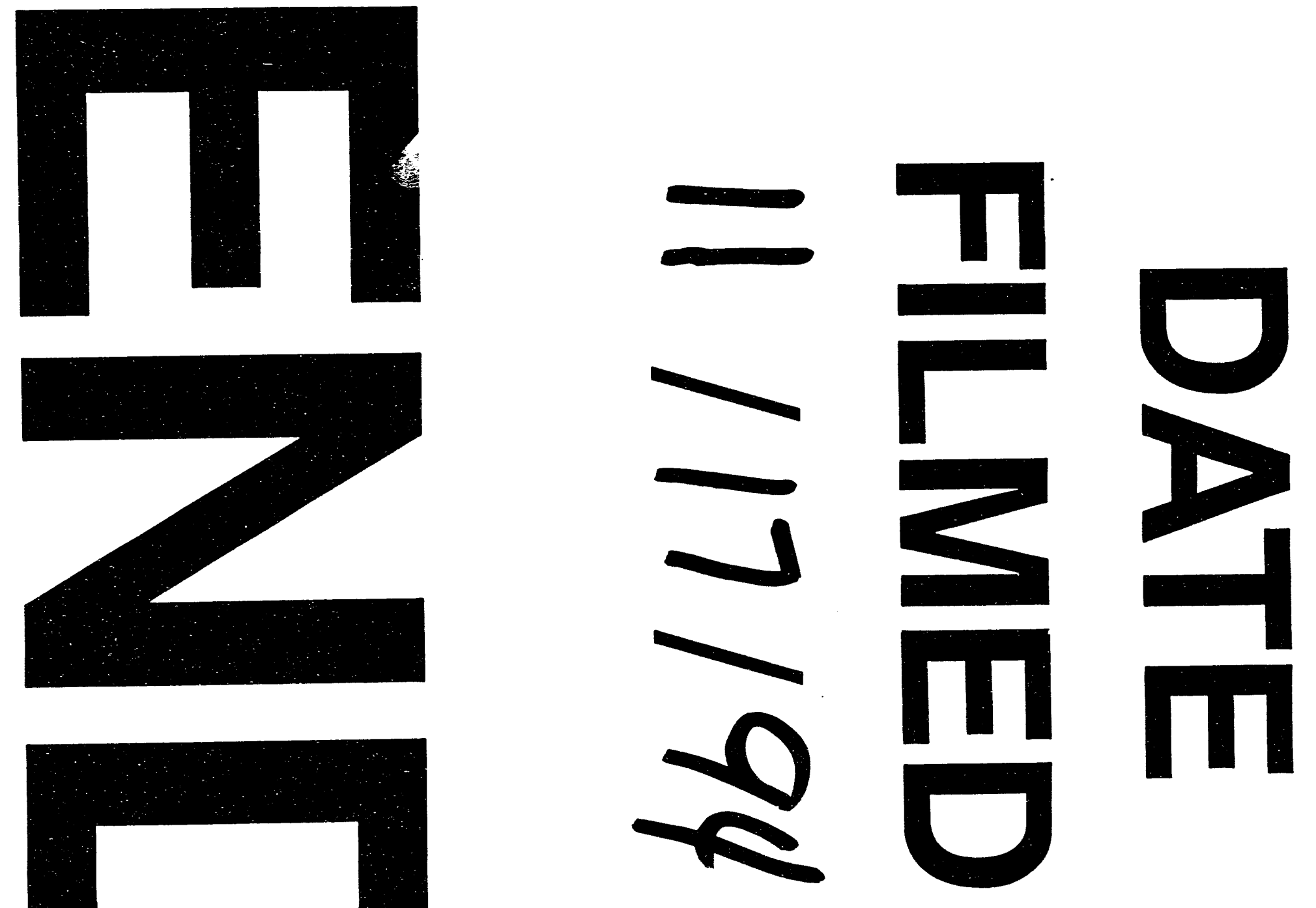